\title{
Self-Assembled Lamellar Nanostructures of Wholly Aromatic Rod-Rod Type Block Molecules
}

\author{
Teruaki Hayakawa, ${ }^{*} \dagger$ Raita Goseki, $\uparrow$ Masa-aki Kakimoto, $\uparrow$ Masatoshi Tokita, \\ $\dagger$ Junji Watanabe, $†$ Yonngui Liao, $\ddagger$ Shin Horiuchi
}

Department of Organic and Polymeric Materials, Graduate School of Science and Engineering, Tokyo Institute of Technology, 2-12-2-S8-26 O-okayama, Meguro-ku, Tokyo 152-8552, Japan, and Nanotechnology Research Institute, National Institute of Advanced Industrial Science and Technology, Central 5, 1-1-1 Higashi, Tsukuba, Ibaraki 305-8565, Japan

thayakaw@o.cc.titech.ac.jp

\section{Supporting Information}

Materials.

4,4'-Difluorodiphenyl sulfone, 4-Methoxy phenol, 4,4'-Difluorobenzophenone and 4-tert-Butulphenol were purchased from Tokyo Chemical Industry Co. Ltd (Tokyo, Japan). Boron tribromide, 99.999\% was purchased from Wako Pure Chemical Co. Ltd (Osaka, Japan). Potassium carbonate was purchased from Takahashi Pure Chemical, Co. Ltd (Tokyo, Japan). Dimethyl- $d_{6}$ sulfoxide was purchased from ISOTEC (Miamisburg). Chloroform- $d$ was purchased from Aldrich. All solvents were used as received.

\section{Characterization}

Thin layer chromatography was performed on Merck silicagel $60 \mathrm{~F}_{254}$. Silica used for chromatography was Fuji silysia chemical BW-127ZH $(150-75 \mu \mathrm{m})$. Infrared spectrum was recorded on a JASCO FT / IR-460 Plus spectrometer. ${ }^{1} \mathrm{H}$ and ${ }^{13} \mathrm{C}$ NMR spectrum were recoded JEOL JNM-AL 300 spectrometer at $300 \mathrm{MHz}$ and $75 \mathrm{MHz}$, respectively. Matrix Assisted Laser Desorption Ionization Time of Flight Mass Spectrometry (MALDI-ToF-MS) was taken on a Shimazu AXIMA-CFR mass spectrometer. The spectrometer was equipped with nitrogen laser $(\lambda=337 \mathrm{~nm})$ and with pulsed ion extraction. The operation was performed at an accelerating potential of $20 \mathrm{kV}$ by a linear-positive ion mode. Samples for MALDI-ToF-MS were prepared by casting the matrix compound (dithranol) onto the slide. Thermal analyses of the compounds, thermogravimetric analysis (TGA) and differential scanning calorimetry (DSC), were carried out using a Seiko SSC / 6000 (TG / DTA 6200 and DSC6200) thermal analyzer with ca. $5 \mathrm{mg}$ of samples at a heating rate of $10{ }^{\circ} \mathrm{C} \mathrm{min}^{-1}$. Nitrogen was used as purge gas at a flow rate of $50 \mathrm{~mL}$ 
$\min ^{-1}$ in TGA and DSC measurements. A polarized optical microscope (OLYMPUS BX51) was used to observe phase transition to an isotropic phase of compounds. Wide-angle X-ray diffraction (WAXD) patterns were recorded on a flat imaging plate by using Ni-filtered $\mathrm{Cu} \mathrm{K} \alpha$ radiation generated by a Rigaku RU-200BH. Small-angle X-ray scattering (SAXS) profiles were obtained using a Bruker NanoSTAR (45 kV / $110 \mathrm{~mA}$ ) with a 2D-PSPC detector (camera length $1055 \mathrm{~nm}$ ). A leo922 Energy-filtering transmission electron microscope (EFTEM), with which an omega-type electron spectrometer is equipped, was operated at an acceleration voltage of $200 \mathrm{kV}$. For specimen preparation, the films after annealed at $160{ }^{\circ} \mathrm{C}$ for OES-b-OEK and $200{ }^{\circ} \mathrm{C}$ for OEK- $b$-OES- $b$-OEK, respectively, after cooling from $250{ }^{\circ} \mathrm{C}$, was sectioned to give thin specimens with $50 \mathrm{~nm}$ thickness after embedding in epoxy resin.

\section{Synthesis of 4-fluoro-4'-(4"'-methoxyphenyloxy)diphenyl sulfone (3)}

A round bottom flask was charged with $10 \mathrm{~g}(39.3 \mathrm{mmol})$ of 4,4'-difluorodiphenyl sulfone,

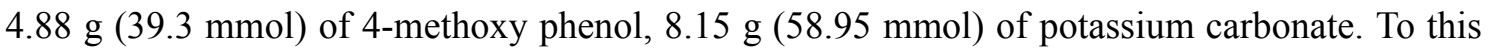
mixture was added $30 \mathrm{~mL}$ of DMAc and the resulting solution was heated to $180{ }^{\circ} \mathrm{C}$ over the course of 4 hours under a nitrogen atmosphere. The reaction mixture was diluted with dichloromethane and washed with saturate $\mathrm{NaCl}$ water for three times to remove DMAc and potassium carbonate. The organic layer was dried over $\mathrm{MgSO}_{4}$, filtered, evaporated. The yellow residue was purified by column chromatography on silica using a 1:1 n-hexane/dichloromethane mixture as the eluent. The solvent was removed and the white solid was dried in vacuo at $40{ }^{\circ} \mathrm{C}$ for 3 hours (6.34 g, $17.7 \mathrm{mmol}, 45 \%)$. IR (KBr): 3094, 1590, 1504, 1489, 1324, 1295, 1233, 1151, 1104, 1031, 845, $832 \mathrm{~cm}^{-1} .{ }^{1} \mathrm{H}$ NMR $\left(\mathrm{CDCl}_{3}\right.$, r.t.): $\delta 7.91(\mathrm{dd}, J=8.8,5.0 \mathrm{~Hz}, 2 \mathrm{H}), 7.81(\mathrm{~d}$, $J=8.8 \mathrm{~Hz}, 2 \mathrm{H}), 7.14(\mathrm{t}, J=8.8 \mathrm{~Hz}, 2 \mathrm{H}), 6.96(\mathrm{~d}, J=9.2 \mathrm{~Hz}, 2 \mathrm{H}), 6.94(\mathrm{~d}, J=8.8 \mathrm{~Hz}, 2 \mathrm{H}), 6.89$ (d, $J=9.2 \mathrm{~Hz}, 2 \mathrm{H}), 3.80$ (s, 3H) ppm; ${ }^{13} \mathrm{C} \mathrm{NMR}\left(\mathrm{CDCl}_{3}\right.$, r.t.): $\delta 166.9,163.5,163.1,156.9$, $147.8,138.18,138.18,134.1,130.2,130.1,129.6,121.7,116.9,116.6,116.3,115.1,55.6$ ppm.

\section{Synthesis of 4-fluoro-4'-(4"'-mehtoxyphenyloxy)diphenyl ketone (4)}

A round bottom flask was charged with $10 \mathrm{~g}$ (45.8 mmol) of 4,4'-difluorobenzophenone, 5.64 $\mathrm{g}(45.8 \mathrm{mmol})$ of 4-methoxy phenol, $9.50 \mathrm{~g}(68.7 \mathrm{mmol})$ of potassium carbonate. To this mixture was added $30 \mathrm{~mL}$ of DMAc and the resulting solution was heated to $180{ }^{\circ} \mathrm{C}$ over the course of 4 hours under a nitrogen atmosphere. The reaction mixture was diluted with dichloromethane and washed with saturate $\mathrm{NaCl}$ water for three times to remove the DMAc and potassium carbonate. The organic layer was dried over $\mathrm{MgSO}_{4}$, filtered, evaporated. The obtained powder was dissolved in ethylacetate, filtered, and then obtained filtrate. The solvent 
was evaporated, recrystallized from methanol gave white solid and dried in vavuo at $80{ }^{\circ} \mathrm{C}$ for 3 hours. (5.45 g, $16.9 \mathrm{mmol}, 37 \%$ ). IR (KBr): 3063, 1643, 1599, 1507, 1244, 1230, 1295, 1150, $1105,1032,843,766 \mathrm{~cm}^{-1} .{ }^{1} \mathrm{H}$ NMR $\left(\mathrm{CDCl}_{3}\right.$, r.t.): $\delta 7.79(\mathrm{dd}, J=8.4,5.5 \mathrm{~Hz}, 2 \mathrm{H}), 7.74(\mathrm{~d}, J=$ $8.4 \mathrm{~Hz}, 2 \mathrm{H}), 7.13(\mathrm{t}, J=8.4 \mathrm{~Hz}, 2 \mathrm{H}), 7.03$ (d, $J=8.8 \mathrm{~Hz}, 2 \mathrm{H}), 6.95$ (d, $J=8.4 \mathrm{~Hz}, 2 \mathrm{H}), 6.91$ (d, $J=8.8 \mathrm{~Hz}, 2 \mathrm{H}), 3.81$ (s, 3H) ppm; ${ }^{13} \mathrm{C} \mathrm{NMR}\left(\mathrm{CDCl}_{3}\right.$, r.t.): $\delta 194.0,166.8,163.4,162.6,156.7$, $148.4,134.1,132.4,131.1,121.7,116.2,115.5,115.2,115.0,55.6 \mathrm{ppm}$.

\section{Synthesis of (5)}

A round bottom flask was charged with a $2 \mathrm{~g}(5.58 \mathrm{mmol})$ sample of $\mathbf{3}, 1.01 \mathrm{~g}(6.67 \mathrm{mmol})$ of 4-tert-butylphenol, $1.39 \mathrm{~g}$ (10.0 mmol) of potassium carbonate. To this mixture was added $4 \mathrm{~mL}$ of DMAc and the resulting solution was heated to $180^{\circ} \mathrm{C}$ over the course of 4 hours under a nitrogen atmosphere. The reaction mixture was diluted with dichloromethane and washed with saturate $\mathrm{NaCl}$ water for three times to remove DMAc and potassium carbonate. The organic layer was dried over $\mathrm{MgSO}_{4}$, filtered, evaporated. The yellow residue was purified by column chromatography on silica using a 1:2 n-hexane/dichloromethane mixture as the eluent. The solvent was removed and the white solid was dried in vacuo at $40{ }^{\circ} \mathrm{C}$ for 3 hours $(2.53 \mathrm{~g}, 5.19$ mmol, 93\%). IR (KBr): 3092, 2951, 1586, 1504, 1487, 1318, 1297, 1229, 1195, 1154, 1105, 1033, 874, $845 \mathrm{~cm}^{-1} .{ }^{1} \mathrm{H}$ NMR $\left(\mathrm{CDCl}_{3}\right.$, r.t.): $\delta 7.82(\mathrm{~d}, J=9.0 \mathrm{~Hz}, 2 \mathrm{H}), 7.81(\mathrm{~d}, J=9.0 \mathrm{~Hz}, 2 \mathrm{H})$, $7.37(\mathrm{~d}, J=8.8 \mathrm{~Hz}, 2 \mathrm{H}), 7.00-6.89(\mathrm{~m}, 10 \mathrm{H}), 3.80(\mathrm{~s}, 3 \mathrm{H}), 1.38(\mathrm{~s}, 9 \mathrm{H}) \mathrm{ppm} ;{ }^{13} \mathrm{C} \mathrm{NMR}\left(\mathrm{CDCl}_{3}\right.$, r.t.): $\delta 162.7,162.2,156.8,152.4,148.0,147.9,135.1,134.9,129.63,129.60,126.9,121.7$, $119.8,117.4,116.8,115.1,55.6,34.4,31.4 \mathrm{ppm}$.

\section{Synthesis of $(6)$}

A $2.53 \mathrm{~g}(5.19 \mathrm{mmol})$ sample of 5 in $30 \mathrm{~mL}$ of dichloromethane was treated dropwise with 5 $\mathrm{mL}(55 \mathrm{mmol})$ of boron tribromide and stirred for 1 hour at $0{ }^{\circ} \mathrm{C}$ under a nitrogen atmosphere. After the homogeneous solution to stir for 5 hours at room temperature, the solution was poured into water $(1 \mathrm{~L})$. The precipitate was filtered, dissolved in dichloromethane, dried over $\mathrm{MgSO}_{4}$, filtered and evaporated. Recrystallized from n-hexane/chloroform (4:1) mixture and dried in vacuo at $40^{\circ} \mathrm{C}$ for 3 hours (1.92 g, $4.0 \mathrm{mmol}, 78 \%$ ). IR (KBr): 3429, 3097, 2962, 1589, 1499 , $1486,1319,1289,1238,1190,1151,1107,872,834 \mathrm{~cm}^{-1} .{ }^{1} \mathrm{H}$ NMR $\left(\mathrm{CDCl}_{3}\right.$, r.t.): $\delta 7.82$ (d, $J=$ $8.8 \mathrm{~Hz}, 2 \mathrm{H}), 7.81(\mathrm{~d}, J=8.8 \mathrm{~Hz}, 2 \mathrm{H}), 7.37$ (d, $J=8.6 \mathrm{~Hz}, 2 \mathrm{H}), 6.98(\mathrm{~d}, J=8.8 \mathrm{~Hz}, 2 \mathrm{H}), 6.94(\mathrm{~d}$, $J=8.6 \mathrm{~Hz}, 2 \mathrm{H}), 6.93(\mathrm{~d}, J=8.8 \mathrm{~Hz}, 2 \mathrm{H}), 6.91(\mathrm{~d}, J=9.1 \mathrm{~Hz}, 2 \mathrm{H}), 6.83(\mathrm{~d}, J=9.1 \mathrm{~Hz}, 2 \mathrm{H})$, 1.31 (s, 9H) ppm; ${ }^{13} \mathrm{C} \mathrm{NMR}\left(\mathrm{CDCl}_{3}\right.$, r.t.): $\delta 162.7,162.2,152.9,152.4,148.08,148.04,135.1$, 134.8, 129.64, 129.61, 126.9, 121.9, 119.8, 117.4, 116.8, 116.6, 34.4, 31.4 ppm. 


\section{Synthesis of (7)}

A round bottom flask was charged with a $2.37 \mathrm{~g}(5.0 \mathrm{mmol})$ sample of $\mathbf{6}$, a $2.15 \mathrm{~g}(6.0 \mathrm{mmol})$ sample of $3,1.04 \mathrm{~g}(7.5 \mathrm{mmol})$ of potassium carbonate. To this mixture was added $2 \mathrm{~mL}$ of DMAc and the resulting solution was heated to $180{ }^{\circ} \mathrm{C}$ over the course of 4 hours under a nitrogen atmosphere. The reaction mixture was diluted with dichloromethane and washed with saturate $\mathrm{NaCl}$ water for three times to remove DMAc and potassium carbonate. The organic layer was dried over $\mathrm{MgSO}_{4}$, filtered, evaporated. The yellow residue was purified by column chromatography on silica using a 1:4 n-hexane/dichloromethane mixture as the eluent. The solvent was removed and the white solid was dried in vacuo at $40{ }^{\circ} \mathrm{C}$ for 3 hours $(3.83 \mathrm{~g}, 4.7$ mmol, 94\%). IR (KBr): 3096, 2960, 1589, 1499, 1486, 1319, 1288, 1237, 1151, 1107, 872, 834 $\mathrm{cm}^{-1} .{ }^{1} \mathrm{H}$ NMR $\left(\mathrm{CDCl}_{3}\right.$, r.t.): $\delta$ 7.87-7.80 (m, 8H), $7.38(\mathrm{~d}, J=8.8 \mathrm{~Hz}, 2 \mathrm{H}), 7.04-6.91(\mathrm{~m}, 18 \mathrm{H})$, $3.80(\mathrm{~s}, 3 \mathrm{H}), 1.31$ (s, 9H) ppm; ${ }^{13} \mathrm{C} \mathrm{NMR}\left(\mathrm{CDCl}_{3}\right.$, r.t.): $\delta 162.8,162.2,161.65,161.63,156.8$, $152.3,151.7,148.0,147.8,135.9,135.7,134.9$, 134.6, 129.79, 129.73, 129.71, 129.65, 129.61, $126.9,121.8,121.7,119.7,117.5,117.4,116.8,115.1,55.5,34.4,31.3$ ppm. MS (MALDI-ToF) $\mathrm{m} / \mathrm{z}$ calcd for $\left(\mathrm{C}_{47} \mathrm{H}_{40} \mathrm{O}_{9} \mathrm{~S}_{2}\right) 812.9$, found $835.5[\mathrm{M}+\mathrm{Na}]^{+}$.

\section{Synthesis of (8)}

A $3.12 \mathrm{~g} \mathrm{(3.84} \mathrm{mmol)} \mathrm{sample} \mathrm{of} 7$ in $30 \mathrm{~mL}$ of dichloromethane was treated dropwise with $4 \mathrm{~mL}$ (42.7 mmol) of boron tribromide and stirred for 1 hour at $0{ }^{\circ} \mathrm{C}$ under a nitrogen atmosphere. After the homogeneous solution to stir for 5 hours at room temperature, the solution was poured into water $(800 \mathrm{~mL})$. The precipitate was filtered and dried in vacuo at $80^{\circ} \mathrm{C}$ for 3 hours $(2.50 \mathrm{~g}$, $3.11 \mathrm{mmol}, 81 \%$ ). IR (KBr): 3434, 3070, 2963, 1589, 1498, 1486, 1319, 1290, 1236, 1189, 1151, 1106, 871, $834 \mathrm{~cm}^{-1} .{ }^{1} \mathrm{H}$ NMR $\left(\mathrm{CDCl}_{3}\right.$, r.t.): $\delta 7.87-7.80(\mathrm{~m}, 8 \mathrm{H}), 7.37(\mathrm{~d}, J=8.6 \mathrm{~Hz}, 2 \mathrm{H})$, 7.04-6.85 (m, 18H), 5.27 (s, $1 \mathrm{H}), 1.31$ (s, 9H) ppm; ${ }^{13} \mathrm{C}$ NMR $\left(\mathrm{CDCl}_{3}\right.$, r.t.): $\delta 162.8,162.3$, 161.68, 161.67, 153.2, 152.2, 151.6, 148.0, 147.5, 135.68, 135.66, 134.6, 134.4, 129.69, 129.66, $129.60,126.9,121.9,121.8,119.7,117.5,117.4,116.8,116.6,34.3,31.3$ ppm. MS (MALDI-ToF) $\mathrm{m} / \mathrm{z}$ calcd for $\left(\mathrm{C}_{46} \mathrm{H}_{38} \mathrm{O}_{9} \mathrm{~S}_{2}\right) 798.92$, found $821.9[\mathrm{M}+\mathrm{Na}]^{+}$.

\section{Synthesis of (9)}

A round bottom flask was charged with a $0.48 \mathrm{~g}(0.59 \mathrm{mmol})$ sample of $\mathbf{8}$, a $0.23 \mathrm{~g}(0.65 \mathrm{mmol})$ sample of $3,0.098 \mathrm{~g}(0.712 \mathrm{mmol})$ of potassium carbonate. To this mixture was added $2 \mathrm{~mL}$ of DMAc and the resulting solution was heated to $180{ }^{\circ} \mathrm{C}$ over the course of 4 hours under a 
nitrogen atmosphere. The reaction mixture was diluted with dichloromethane and washed with saturate $\mathrm{NaCl}$ water for three times to remove DMAc and potassium carbonate. The organic layer was dried over $\mathrm{MgSO}_{4}$, filtered, evaporated. The brown residue was purified by column chromatography on silica using a dichloromethane. The solvent was removed and the white solid was dried in vacuo at $40{ }^{\circ} \mathrm{C}$ for 3 hours (0.66 g, $\left.0.58 \mathrm{mmol}, 98 \%\right)$. IR (KBr): 3097, 2962, $1589,1499,1486,1320,1289,1235,1189,1151,1107,871,834 \mathrm{~cm}^{-1} .{ }^{1} \mathrm{H}$ NMR $\left(\mathrm{CDCl}_{3}\right.$, r.t.): $\delta$ 7.88-7.80 (m, 12H), 7.37 (d, $J=8.5 \mathrm{~Hz}, 2 \mathrm{H}), 7.05-6.87(\mathrm{~m}, 26 \mathrm{H}), 3.79(\mathrm{~s}, 3 \mathrm{H}), 1.31(\mathrm{~s}, 9 \mathrm{H})$ ppm; ${ }^{13} \mathrm{C} \mathrm{NMR}\left(\mathrm{CDCl}_{3}\right.$, r.t.): $\delta 162.8,162.3,161.7,161.63,161.62,156.8,152.2,151.7,151.6$, 148.0, 147.8, 135.9, 135.8, 135.6, 134.8, 134.6, 129.8, 129.73, 129.71, 129.66, 129.64, 126.9, $121.9,121.7,119.8,117.5,117.4,116.8,115.1,55.6,34.4,31.3$ ppm. MS (MALDI-ToF) $\mathrm{m} / \mathrm{z}$ calcd for $\left(\mathrm{C}_{65} \mathrm{H}_{52} \mathrm{O}_{13} \mathrm{~S}_{3}\right)$ 1137.3, found $1138.7[\mathrm{M}]^{+}, 1160.8[\mathrm{M}+\mathrm{Na}]^{+}$.

\section{Synthesis of (10)}

A $0.65 \mathrm{~g}(0.57 \mathrm{mmol})$ sample of 9 in $14 \mathrm{~mL}$ of dichloromethane was treated dropwise with 1 $\mathrm{mL}(10 \mathrm{mmol})$ of boron tribromide and stirred for 1 hour at $0{ }^{\circ} \mathrm{C}$ under a nitrogen atmosphere. After the homogeneous solution to stir for 5 hours at room temperature, the solution was poured into water $(400 \mathrm{~mL})$. The precipitate was filtered and dried in vacuo at $80^{\circ} \mathrm{C}$ for 3 hours $(0.58 \mathrm{~g}$, $0.51 \mathrm{mmol}, 90 \%)$. IR (KBr) 3436, 3096, 3069, 1589, 1486, 1320, 1295, 1233, 1188, 1150, 1106, $869,834 \mathrm{~cm}^{-1} .{ }^{1} \mathrm{H}$ NMR $\left(\mathrm{CDCl}_{3}\right.$, r.t.): $\delta 7.88-7.79(\mathrm{~m}, 12 \mathrm{H}), 7.37$ (d, $\left.J=8.6 \mathrm{~Hz}, 2 \mathrm{H}\right), 7.04-6.86$ (m, 26H), 1.31 (s, 9H) ppm; ${ }^{13} \mathrm{C} \mathrm{NMR}\left(\mathrm{CDCl}_{3}\right.$, r.t.): $\delta 162.9,162.4,161.8,161.7,161.6,153.6$, 152.4, 151.98, 151.97, 151.8, 148.1, 147.7, 136.2, 136.1, 135.8, 135.0, 134.7, 129.87, 129.81, $129.79,129.71,126.9,121.9,121.8,119.8,117.7,117.5,116.9,116.7,34.4,31.4$ ppm. MS (MALDI-ToF) $m / z$ calcd for $\left(\mathrm{C}_{64} \mathrm{H}_{50} \mathrm{O}_{13} \mathrm{~S}_{3}\right)$ 1123.27, found $1146.1[\mathrm{M}+\mathrm{Na}]^{+}$.

\section{Synthesis of (11)}

A round bottom flask was charged with a $0.35 \mathrm{~g}(0.31 \mathrm{mmol})$ sample of $\mathbf{1 0}$, a $0.12 \mathrm{~g}(0.37$ $\mathrm{mmol})$ sample of $4,0.051 \mathrm{~g}(0.37 \mathrm{mmol})$ of potassium carbonate. To this mixture was added 1.5 $\mathrm{mL}$ of DMAc and the resulting solution was heated to $180{ }^{\circ} \mathrm{C}$ over the course of 4 hours under a nitrogen atmosphere. The reaction mixture was diluted with dichloromethane and washed with saturate $\mathrm{NaCl}$ water for three times to remove DMAc and potassium carbonate. The organic layer was dried over $\mathrm{MgSO}_{4}$, filtered, evaporated. The brown residue was purified by column chromatography on silica using a dichloromethane. The solvent was removed and the white solid was dried in vacuo at $40{ }^{\circ} \mathrm{C}$ for 3 hours $(0.37 \mathrm{~g}, 0.26 \mathrm{mmol}, 84 \%)$. IR (KBr): 3068, 2961, 
$1652,1590,1486,1322,1297,1230,1150,1106,865,836 \mathrm{~cm}^{-1} .{ }^{1} \mathrm{H}$ NMR $\left(\mathrm{CDCl}_{3}\right.$, r.t.): $\delta$ 7.89-7.73 (m, 16H), 7.36 (d, $J=8.8 \mathrm{~Hz}, 2 \mathrm{H}), 7.08-6.88$ (m, 34H), 3.79 (s, 3H), 1.30 (s, 9H) ppm; ${ }^{13} \mathrm{C}$ NMR $\left(\mathrm{CDCl}_{3}\right.$, r.t.): $\delta$ 194.0, 162.3, 162.2, 161.9, 161.74, 161.72, 161.6, 161.5, 160.9, $156.5,152.5,152.2,151.7,151.68,151.64,151.60,151.1,148.4,148.0,135.8,135.66,135.60$, 135.5, 135.4, 134.8, 132.5, 132.1, 131.4, 129.76, 129.70, 129.6, 126.9, 121.9, 121.59, 121.57, $119.7,117.5,117.4,117.3,117.0,116.1,114.9,55.5,34.3,31.3$ ppm. MS (MALDI-ToF) $\mathrm{m} / \mathrm{z}$ calcd for $\left(\mathrm{C}_{84} \mathrm{H}_{64} \mathrm{O}_{16} \mathrm{~S}_{3}\right)$ 1425.6, found $1426.7[\mathrm{M}]^{+}, 1449.1[\mathrm{M}+\mathrm{Na}]^{+}$.

\section{Synthesis of (12)}

A $0.36 \mathrm{~g}(0.26 \mathrm{mmol})$ sample of $\mathbf{1 1}$ in $14 \mathrm{~mL}$ of dichloromethane was treated dropwise with 1 $\mathrm{mL}(10 \mathrm{mmol})$ of boron tribromide and stirred for 1 hour at $0{ }^{\circ} \mathrm{C}$ under a nitrogen atmosphere. After the homogeneous solution to stir for 5 hours at room temperature, the solution was poured into water $(400 \mathrm{~mL})$. The precipitate was filtered and dried in vacuo at $80{ }^{\circ} \mathrm{C}$ for 3 hours $(0.30 \mathrm{~g}$, 0.21 mmol, 81\%). IR (KBr): 3435, 3069, 2963, 1651, 1590, 1486, 1319, 1296, 1230, 1188, 1150 , 1106, 867, $835 \mathrm{~cm}^{-1} .{ }^{1} \mathrm{H}$ NMR $\left(\mathrm{CDCl}_{3}\right.$, r.t.): $\delta 7.88-7.73(\mathrm{~m}, 16 \mathrm{H}), 7.37(\mathrm{~d}, J=8.6 \mathrm{~Hz}, 2 \mathrm{H})$, 7.11-6.84 (m, 34H), 1.31 (s, 9H) ppm; ${ }^{13} \mathrm{C} \mathrm{NMR}\left(\mathrm{CDCl}_{3}\right.$, r.t.): $\delta 194.2,162.5,162.3,162.0$, $161.85,161.82$, 161.7, 161.6, 161.1, 153.1, 152.7, 152.4, 151.9, 151.88, 151.84, 151.7, 151.3, $148.4,148.1,136.0,135.9,135.8,135.7,135.6,135.0,132.7,132.2,131.5,129.8,129.79$, $129.70,126.9,121.9,121.8,121.7,121.6,119.8,117.7,117.6,117.5,117.1,116.6,116.2,34.4$, $31.4 \mathrm{ppm}$. MS (MALDI-ToF) $\mathrm{m} / z$ calcd for $\left(\mathrm{C}_{83} \mathrm{H}_{62} \mathrm{O}_{16} \mathrm{~S}_{3}\right)$ 1411.5, found $1412.5[\mathrm{M}]^{+}, 1434.8$ $[\mathrm{M}+\mathrm{Na}]^{+}$

\section{Synthesis of diblock OES-b-OEK (1)}

A round bottom flask was charged with a $0.30 \mathrm{~g}(0.21 \mathrm{mmol})$ sample of 11 , a $0.081 \mathrm{~g}(0.25$ mmol) sample of $4,0.035 \mathrm{~g}(0.25 \mathrm{mmol})$ of potassium carbonate. To this mixture was added 1 $\mathrm{mL}$ of DMAc and the resulting solution was heated to $180^{\circ} \mathrm{C}$ over the course of 4 hours under a nitrogen atmosphere. The reaction mixture was diluted with dichloromethane and washed with saturate $\mathrm{NaCl}$ water for three times to remove DMAc and potassium carbonate. The organic layer was dried over $\mathrm{MgSO}_{4}$, filtered, evaporated. The brown residue was purified by column chromatography on silica using a dichloromethane. The solvent was removed and the solid was dried in vacuo at $40{ }^{\circ} \mathrm{C}$ for 3 hours $(0.26 \mathrm{~g}, 0.15 \mathrm{mmol}, 72 \%)$. $T_{\mathrm{g}}$ (DSC) $119{ }^{\circ} \mathrm{C}$. m.p. (DSC) $202{ }^{\circ} \mathrm{C}$. IR (KBr): 3068, 2960, 1645, 1591, 1486, 1317, 1296, 1230, 1188, 1150, 1105, 868, 835 $\mathrm{cm}^{-1} .{ }^{1} \mathrm{H}$ NMR (DMSO- $d_{6}$, r.t.): $\delta$ 7.93-7.87 (m, 12H), $7.77(\mathrm{~m}, 8 \mathrm{H}), 7.41(\mathrm{~d}, J=8.3 \mathrm{~Hz}, 2 \mathrm{H})$, 7.16-6.99 (m, 42H), 3.80 (s, 3H), 1.31 (s, 9H)ppm; ${ }^{13} \mathrm{C} \mathrm{NMR} \mathrm{(} \mathrm{CDCl}_{3}$, r.t.): $\delta$ 194.0, 162.2, 161.9, 
161.7, 161.6, 161.4, 161.2, 156.6, 152.5, 152.4, 151.88, 151.81, 151.3, 148.6, 148.0, 136.0, 135.8, 135.6, 135.0, 132.5, 132.1, 131.6, 129.7, 129.6, 126.9, 121.8, 121.5, 119.7, 117.6, 117.4, $117.1,117.0,116.2,115.0,55.6,34.3,31.3 \mathrm{ppm}$. MS (MALDI-ToF) $\mathrm{m} / \mathrm{z}$ calcd for $\left(\mathrm{C}_{103} \mathrm{H}_{76} \mathrm{O}_{19} \mathrm{~S}_{3}\right)$ 1712.4, found $1712.9[\mathrm{M}]^{+}, 1734.8[\mathrm{M}+\mathrm{Na}]^{+}$.

\section{Synthesis of 4,4'-(4", 4"'-dimethoxyphenyloxy)diphenyl sulfone (18)}

A round bottom flask was charged with $5.085 \mathrm{~g}(20.0 \mathrm{mmol})$ of 4,4'-difluorodiphenyl sulfone, $4.967 \mathrm{~g}$ (40.0 mmol) of 4-methoxyphenol, $6.08 \mathrm{~g}$ (44.0 mmol) of potassium carbonate. To this mixture was added $30 \mathrm{~mL}$ of DMAc and the resulting solution was heated to $180{ }^{\circ} \mathrm{C}$ over the course of 4 hours under a nitrogen atmosphere. The reaction mixture was diluted with dichloromethane and washed with saturate $\mathrm{NaCl}$ water for three times to remove DMAc and potassium carbonate. The organic layer was dried over $\mathrm{MgSO}_{4}$, filtered, evaporated. The white solid was recrystallized from the mixture of $n$-hexane/chloroform $(5: 1)$, filtered and dried in vacuo at $60^{\circ} \mathrm{C}$ for 3 hours (7.99 g, $\left.18.6 \mathrm{mmol}, 93 \%\right)$. IR (KBr): 3070, 1589, 1499, 1486, 1319, 1289, 1237, 1150, 1107, 872, $834 \mathrm{~cm}^{-1} .{ }^{1} \mathrm{H}$ NMR $\left(\mathrm{CDCl}_{3}\right.$, r.t.): $\delta 7.74(\mathrm{~d}, J=8.8 \mathrm{~Hz}, 2 \mathrm{H}), 7.05$ $(\mathrm{d}, J=8.8 \mathrm{~Hz} 2 \mathrm{H}), 6.94(\mathrm{~d}, J=8.8 \mathrm{~Hz}, 2 \mathrm{H}), 6.91(\mathrm{~d}, J=8.8 \mathrm{~Hz}, 2 \mathrm{H}), 3.75(\mathrm{~s}, 3 \mathrm{H}) \mathrm{ppm} ;{ }^{13} \mathrm{C}$ NMR (DMSO- $d_{6}$, r.t.): $\delta 162.2,156.5,147.3,134.6,129.6,121.7,116.8,115.2,55.3$ ppm.

\section{Synthesis of (13)}

A $5.94 \mathrm{~g}$ (13.8 mmol) sample of $\mathbf{1 8}$ in $200 \mathrm{~mL}$ of dichloromethane was treated dropwise with 10 $\mathrm{mL}(110 \mathrm{mmol})$ of boron tribromide and stirred for 1 hour at $0{ }^{\circ} \mathrm{C}$ under a nitrogen atmosphere. After the homogeneous solution to stir for 5 hours at room temperature, the solution was poured into water $(2 \mathrm{~L})$. The precipitate was filtered and dried in vacuo at $80{ }^{\circ} \mathrm{C}$ for 3 hours $(5.22 \mathrm{~g}$, 12.3 mmol, 89\%). IR (KBr): 3378, 3093, 1590, 1507, 1488, 1451, 1293, 1232, 1194, 1142, 1106 , $1070,875,835 \mathrm{~cm}^{-1} .{ }^{1} \mathrm{H}$ NMR (DMSO-d 6 , r.t.): $\delta 9.52$ (s, $\left.2 \mathrm{H}\right), 7.85(\mathrm{~d}, J=9.0 \mathrm{~Hz}, 4 \mathrm{H}), 6.98$ (d, $J=9.0 \mathrm{~Hz}, 4 \mathrm{H}), 6.94(\mathrm{~d}, J=8.8 \mathrm{~Hz}, 4 \mathrm{H}), 6.80(\mathrm{~d}, J=8.8 \mathrm{~Hz}, 4 \mathrm{H}) \mathrm{ppm} ;{ }^{13} \mathrm{C}$ NMR (DMSO- $d_{6}$, r.t.): $\delta 162.6,154.9,146.0,134.5,129.7,121.9,116.7,116.5 \mathrm{ppm}$.

\section{Synthesis of (14)}

A round bottom flask was charged with a $1.2 \mathrm{~g}(2.75 \mathrm{mmol})$ sample of 13 , a $2.36 \mathrm{~g}(6.60$ mmol) sample of $\mathbf{3}, 1.30 \mathrm{~g}$ ( $8.25 \mathrm{mmol})$ of potassium carbonate. To this mixture was added 3 $\mathrm{mL}$ of DMAc and the resulting solution was heated to $180{ }^{\circ} \mathrm{C}$ over the course of 4 hours under a nitrogen atmosphere. The reaction cooled down to room temperature and the product was 
filtered and washed with water and methanol. The filtered white solid was made to conduct a Soxhlet extraction with methanol to remove excess compound $\mathbf{3}$ and dried in vacuo at $80{ }^{\circ} \mathrm{C}$ for 3 hours (2.95 g, $2.65 \mathrm{mmol}, 96 \%$ ). $T_{\mathrm{g}}$ (DSC) $128{ }^{\circ} \mathrm{C}$. IR (KBr): 3070, 1590, 1500, 1485, 1318, $1288,1236,1190,1150,1107,872,834 \mathrm{~cm}^{-1} .{ }^{1} \mathrm{H}$ NMR (DMSO- $d_{6}$, r.t.): $\delta 7.93-7.87(\mathrm{~m}, 6 \mathrm{H})$, 7.21-6.97 (m, 14H), 3.75 (s, 3H) ppm; ${ }^{13} \mathrm{C}$ NMR (DMSO- $d_{6}$, at $120{ }^{\circ} \mathrm{C}$ ): $\delta 161.6,160.8,160.7$, $156.2,151.14,151.10,147.5,135.4,135.2,134.5,129.2,129.1,129.0,121.2,120.8,117.4$, $116.7,115.0,55.1 \mathrm{ppm}$.

\section{Synthesis of (15)}

A $2.22 \mathrm{~g}(2.0 \mathrm{mmol})$ sample of $\mathbf{1 4}$ in $35 \mathrm{~mL}$ of dichloromethane was treated dropwise with 4 $\mathrm{mL}$ (43 mmol) of boron tribromide and stirred for 1 hour at $0{ }^{\circ} \mathrm{C}$ under a nitrogen atmosphere. After the homogeneous solution to stir for 5 hours at room temperature, the solution was poured into water $(1 \mathrm{~L})$. The precipitate was filtered and dried in vacuo at $80{ }^{\circ} \mathrm{C}$ for 3 hours $(2.13 \mathrm{~g}$, 1.96 mmol, 98\%). IR (KBr): 3379, 3091, 1591, 1506, 1488, 1450, 1294, 1231, 1195, 1141, 1106, $1073,875,836 \mathrm{~cm}^{-1} .{ }^{1} \mathrm{H}$ NMR (DMSO-d $d_{6}$, r.t.): $\delta 9.57$ (br, $\left.1 \mathrm{H}\right), 7.93-7.85$ (m, 6H), 7.19-7.11 (m, $8 \mathrm{H}), 6.99(\mathrm{~d}, J=8.8 \mathrm{~Hz}, 2 \mathrm{H}), 6.93(\mathrm{~d}, J=8.1 \mathrm{~Hz}, 2 \mathrm{H}), 6.80(\mathrm{~d}, J=8.1 \mathrm{~Hz}, 2 \mathrm{H}) \mathrm{ppm} ;{ }^{13} \mathrm{C} \mathrm{NMR}$ (DMSO- $d_{6}$, r.t.): $\delta 162.7,161.6,161.5,154.9,151.4,151.3,146.0,135.5,135.2,134.3,129.9$, $129.8,122.4,121.9,117.8,116.8,116.6 \mathrm{ppm}$. MS (MALDI-ToF) $\mathrm{m} / z$ calcd for $\left(\mathrm{C}_{60} \mathrm{H}_{42} \mathrm{O}_{14} \mathrm{~S}_{3}\right)$ 1083.17, found $1082.6[\mathrm{M}]^{+}, 1106.7[\mathrm{M}+\mathrm{Na}]^{+}$.

\section{Synthesis of (16)}

A round bottom flask was charged with a $0.65 \mathrm{~g}(0.60 \mathrm{mmol})$ sample of 15 , a $0.45 \mathrm{~g}(1.44$ mmol) sample of $4,0.25 \mathrm{~g}(1.80 \mathrm{mmol})$ of potassium carbonate. To this mixture was added 1 $\mathrm{mL}$ of DMAc and the resulting solution was heated to $180^{\circ} \mathrm{C}$ over the course of 4 hours under a nitrogen atmosphere. The reaction cooled down to room temperature and the product was filtered and washed with water and methanol. The filtered white solid was made to conduct a Soxhlet extraction with methanol to remove excess compound $\mathbf{4}$ and dried in vacuo at $80{ }^{\circ} \mathrm{C}$ for 3 hours (0.71 g, $0.42 \mathrm{mmol}, 70 \%$ ). IR (KBr): 3069, 1651, 1594, 1486, 1318, 1297, 1231, 1189, 1151, 1107, 870, $835 \mathrm{~cm}^{-1} .{ }^{1} \mathrm{H}$ NMR (DMSO- $d_{6}$, r.t.): $\delta$ 7.93-7.89 (m, 6H), 7.74 (d, d $J=5.5 \mathrm{~Hz}$, $4 \mathrm{H}), 7.21-7.19(\mathrm{~m}, 8 \mathrm{H}), 7.14-7.08(\mathrm{~m}, 10 \mathrm{H}), 7.01-6.97(\mathrm{~m}, 4 \mathrm{H}), 3.75(\mathrm{~s}, 6 \mathrm{H}) \mathrm{ppm} ;{ }^{13} \mathrm{C} \mathrm{NMR}$ (DMSO- $d_{6}$, at $120{ }^{\circ} \mathrm{C}$ ): $\delta 192.4,161.0,160.9,160.8,160.0,155.9,151.7,151.1,150.7,148.1$, 135.2, 135.1, 132.0, 131.1, 129.1, 121.2, 120.9, 120.6, 117.48, 117.40, 116.7, 116.0, 115.0, 55.1 ppm. 


\section{Synthesis of (17)}

A $0.65 \mathrm{~g}(0.39 \mathrm{mmol})$ sample of $\mathbf{1 6}$ in $14 \mathrm{~mL}$ of dichloromethane was treated dropwise with 1 $\mathrm{mL}(11 \mathrm{mmol})$ of boron tribromide and stirred for 1 hour at $0{ }^{\circ} \mathrm{C}$ under a nitrogen atmosphere. After the homogeneous solution to stir for 5 hours at room temperature, the solution was poured into water $(500 \mathrm{~mL})$. The precipitate was filtered and dried in vacuo at $80^{\circ} \mathrm{C}$ for 3 hours $(0.56 \mathrm{~g}$, 0.34 mmol, 87\%). IR (KBr): 3444, 3069, 1645, 1593, 1497, 1487, 1316, 1288, 1233, 1189, 1150, $1107,869,835 \mathrm{~cm}^{-1} .{ }^{1} \mathrm{H}$ NMR (DMSO- $d_{6}$, r.t.): $\delta 9.45(\mathrm{~s}, 1 \mathrm{H}), 7.86-7.83(\mathrm{~m}, 6 \mathrm{H}), 7.69-7.64(\mathrm{~m}$, $4 \mathrm{H}), 7.14-7.01(\mathrm{~m}, 8 \mathrm{H}), 7.07-7.01(\mathrm{~m}, 8 \mathrm{H}), 6.92-6.89(\mathrm{~m}, 4 \mathrm{H}), 6.77-6.73(\mathrm{~d}, J=8.8 \mathrm{~Hz} 2 \mathrm{H})$ ppm; ${ }^{13} \mathrm{C}$ NMR (DMSO- $d_{6}$, at $120{ }^{\circ} \mathrm{C}$ ): $\delta 192.4,161.4,160.9,160.8,160.0,153.9,151.7,151.1$, 150.7, 146.6, 135.29, 135.25, 135.1, 132.0, 131.1, 130.9, 129.1, 121.25, 121.21, 120.9, 120.6, 117.47, 117.40, 116.7, 116.0, $115.7 \mathrm{ppm}$. MS (MALDI-ToF) $\mathrm{m} / z$ calcd for $\left(\mathrm{C}_{98} \mathrm{H}_{66} \mathrm{O}_{20} \mathrm{~S}_{3}\right)$ 1659.76, found $1659.3[\mathrm{M}]^{+}, 1681.4[\mathrm{M}+\mathrm{Na}]^{+}$.

\section{Synthesis of triblock OEK- $b$-OES- $b$-OEK (2)}

A round bottom flask was charged with a $0.50 \mathrm{~g}(0.30 \mathrm{mmol})$ sample of 17 , a $0.23 \mathrm{~g}(0.72$ mmol) sample of 4, $0.12 \mathrm{~g}(0.90 \mathrm{mmol})$ of potassium carbonate. To this mixture was added 1 $\mathrm{mL}$ of DMAc and the resulting solution was heated to $180{ }^{\circ} \mathrm{C}$ over the course of 4 hours under a nitrogen atmosphere. The reaction cooled down to room temperature and the product was filtered and washed with water and methanol. The solid product was made to conduct a Soxhlet extraction with methanol to remove excess compound 4 and dried in vacuo at $80{ }^{\circ} \mathrm{C}$ for 3 hours (0.64 g, 0.29 mmol, 96\%). $T_{\mathrm{g}}$ (DSC) $126{ }^{\circ} \mathrm{C}$. m.p. (DSC) $223{ }^{\circ} \mathrm{C}$. IR (KBr): 3067, 1646, 1597, $1487,1312,1229,1188,1150,1106,930,866,836 \mathrm{~cm}^{-1} .{ }^{1} \mathrm{H}$ NMR (DMSO- ${ }_{6}$, r.t.): $\delta 7.91-7.89$ $(\mathrm{m}, 6 \mathrm{H}), 7.79-7.72(\mathrm{~m}, 8 \mathrm{H}), 7.20-6.98(\mathrm{~m}, 30 \mathrm{H}), 3.78(\mathrm{~s}, 3 \mathrm{H}) \mathrm{ppm} ;{ }^{13} \mathrm{C}$ NMR (DMSO- $d_{6}$, at 130 $\left.{ }^{\circ} \mathrm{C}\right): \delta 192.4,160.9,160.8,160.7,160.1,160.0,155.9,151.7,151.46,151.40,151.3,151.1$, $150.7,135.2,131.9,131.0,129.0,121.1,120.7,120.49,120.44,117.4,116.7,116.0,114.9,55.1$ ppm.

\section{Synthesis of hydroxyl terminated triblock OEK- $b$-OES- $b$-OEK (19)}

$0.45 \mathrm{~g}(0.2 \mathrm{mmol})$ of 2 in $14 \mathrm{~mL}$ of dichloromethane was treated dropwise with $1 \mathrm{~mL}(11$ mmol) of boron tribromide and stirred for 1 hour at $0{ }^{\circ} \mathrm{C}$ under a nitrogen atmosphere. After the heterogeneous solution to stir 5 hours at room temperature, the solution was poured into water $(500 \mathrm{~mL})$. The precipitate was filtered and dried in vacuo at $80{ }^{\circ} \mathrm{C}$ for 3 hours $(0.38 \mathrm{~g} 0.17$ mmol 85 \%). IR (KBr): 3444, 3069, 1645, 1593, 1497, 1487, 1316, 1288, 1233, 1189, 1150, 
$1107,869,835 \mathrm{~cm}^{-1} .{ }^{1} \mathrm{H}$ NMR (DMSO- $d_{6}$, r.t.): $\delta 9.50(\mathrm{~s}, 1 \mathrm{H}), 7.92-7.89(\mathrm{~m}, 6 \mathrm{H}), 7.78-7.70(\mathrm{~m}$, $8 \mathrm{H}), 7.24-7.12(\mathrm{~m}, 24 \mathrm{H}), 6.98-6.95(\mathrm{~m}, 4 \mathrm{H}), 6.81(\mathrm{~d}, J=8.7 \mathrm{~Hz}, 2 \mathrm{H}) \mathrm{ppm} ;{ }^{13} \mathrm{C}$ NMR (DMSO- $d_{6}$, at $\left.120^{\circ} \mathrm{C}\right): \delta 192.5,161.4,160.9,160.8,160.2,160.1,153.9,151.7,151.4,151.3,151.1,150.7$, $146.7,135.2,135.1,131.99,131.90,131.8,131.2,131.1,130.9,129.1,121.2,120.8,120.6$, $117.47,117.40,116.79,116.72,116.0,115.7 \mathrm{ppm}$. MS (MALDI-ToF) $\mathrm{m} / \mathrm{z}$ calcd for $\left(\mathrm{C}_{136} \mathrm{H}_{90} \mathrm{O}_{26} \mathrm{~S}_{3}\right)$ 2236.4, found $2236.7[\mathrm{M}]^{+}, 2259.1[\mathrm{M}+\mathrm{Na}]^{+}$.

\section{Synthesis of 4-(4"'-tert-butylphenyloxy)-4'-(4"'-methoxyphenyloxy) benzophenone (20)}

A round bottom flask was charged with a $2 \mathrm{~g}(6.20 \mathrm{mmol})$ sample of $4,1.13 \mathrm{~g}(7.50 \mathrm{mmol})$ of 4-tert-butylphenol, $1.55 \mathrm{~g}(11.2 \mathrm{mmol})$ of potassium carbonate. To this mixture was added 8.6 $\mathrm{mL}$ of DMAc and the resulting solution was heated to $180{ }^{\circ} \mathrm{C}$ over the course of 4 hours under a nitrogen atmosphere. The reaction mixture was diluted with dichloromethane and washed with saturate $\mathrm{NaOH}$ and $\mathrm{NaCl}$ water for three times to remove DMAc, potassium carbonate and excess 4-tert-butylphenol. The organic layer was dried over $\mathrm{MgSO}_{4}$, filtered, evaporated. The white solid was recrystallized from the mixture of $n$-hexane/chloroform (4:1) gave white solid and dried in vacuo at $40^{\circ} \mathrm{C}$ for 3 hours $(2.31 \mathrm{~g}, 5.1 \mathrm{mmol}, 83 \%)$. IR (KBr): 3059, 2996, 1644, $1596,1500,1312,1235,1161,1150,1113,1105,1036,876,836 \mathrm{~cm}^{-1} .{ }^{1} \mathrm{H}$ NMR $\left(\mathrm{CDCl}_{3}\right.$, r.t. $): \delta$ $7.76(\mathrm{~d}, J=8.8 \mathrm{~Hz}, 2 \mathrm{H}), 7.75$ (d, $J=8.8 \mathrm{~Hz}, 2 \mathrm{H}), 7.33$ (d, $J=8.4 \mathrm{~Hz}, 2 \mathrm{H}), 7.04-6.89(\mathrm{~m}, 10 \mathrm{H})$, 3.81 (s, 3H), 1.32 (s, 9H) ppm; ${ }^{13} \mathrm{C}$ NMR $\left(\mathrm{CDCl}_{3}\right.$, r.t.): $\delta$ 194.3, 162.3, 161.6, 156.6, 153.0, 148.6, 147.4, 132.2, 132.1, 132.0, 131.7, 126.8, 121.6, 119.6, 116.9, 116.2, 115.0, 55.6, 34.4, $31.4 \mathrm{ppm}$.

\section{Synthesis of (21)}

A $1.46 \mathrm{~g}$ (3.30 mmol) sample of $\mathbf{2 0}$ in $36 \mathrm{~mL}$ of dichloromethane was treated dropwise with 3 $\mathrm{mL}$ (33 mmol) of boron tribromide and stirred for 1 hour at $0{ }^{\circ} \mathrm{C}$ under a nitrogen atmosphere. After the homogeneous solution to stir for 5 hours at room temperature, the solution was poured into water $(1 \mathrm{~L})$. The precipitate was filtered and dried in vacuo at $80{ }^{\circ} \mathrm{C}$ for 3 hours. $(1.30 \mathrm{~g}$, 3.0 mmol, 91\%). IR (KBr): 3349, 3065, 2962, 1644, 1597, 1500, 1458, 1416, 1364, 1311, 1284 , 1240, 1194, 1160, 1112, 839, $819 \mathrm{~cm}^{-1} .{ }^{1} \mathrm{H}$ NMR $\left(\mathrm{CDCl}_{3}\right.$, r.t. $): \delta 7.77(\mathrm{~d}, J=8.8 \mathrm{~Hz}, 2 \mathrm{H}), 7.76(\mathrm{~d}$, $J=8.8 \mathrm{~Hz}, 2 \mathrm{H}), 7.39$ (d, $J=8.4 \mathrm{~Hz}, 2 \mathrm{H}), 7.00(\mathrm{~d}, J=8.8 \mathrm{~Hz} 4 \mathrm{H}), 6.96-6.93(\mathrm{~m}, 4 \mathrm{H}), 6.86$ (d, $J$ $=8.4 \mathrm{~Hz}, 2 \mathrm{H}), 5.81(\mathrm{br}, 1 \mathrm{H}), 1.32(\mathrm{~s}, 9 \mathrm{H}) \mathrm{ppm} ;{ }^{13} \mathrm{C} \mathrm{NMR}\left(\mathrm{CDCl}_{3}\right.$, r.t. $): \delta 194.9,162.5,161.8$, $152.9,148.3,147.5,132.33,132.30,131.7,131.5,126.8,121.8,119.6,116.8,116.5,116.1,34.4$, $31.4 \mathrm{ppm}$. 


\section{Synthesis of OEK dimer (22)}

A round bottom flask was charged with a $1.30 \mathrm{~g}(3.0 \mathrm{mmol})$ sample of 21, a $1.16 \mathrm{~g}(3.6 \mathrm{mmol})$ sample of 4, $0.62 \mathrm{~g}(4.5 \mathrm{mmol})$ of potassium carbonate. To this mixture was added $2 \mathrm{~mL}$ of DMAc and the resulting solution was heated to $180{ }^{\circ} \mathrm{C}$ over the course of 4 hours under a nitrogen atmosphere. The reaction cooled down to room temperature and the product was filtered and washed with water and methanol. The filtered white solid was made to conduct a Soxhlet extraction with methanol to remove excess compound 4 and dried in vacuo at $80{ }^{\circ} \mathrm{C}$ for 3 hours (2.10 g, 2.8 mmol, 93\%). m.p. (DSC) $213{ }^{\circ} \mathrm{C}$. IR (KBr): 3059, 2960, 1644, 1597, 1507, $1463,1312,1247,1162,1149,835,765 \mathrm{~cm}^{-1} .{ }^{1} \mathrm{H}$ NMR $\left(\mathrm{CDCl}_{3}\right.$, r.t.): $\delta 7.82-7.72(\mathrm{~m}, 8 \mathrm{H}), 7.39$ $(\mathrm{d}, J=8.4 \mathrm{~Hz}, 2 \mathrm{H}), 7.04-6.91(\mathrm{~m}, 18 \mathrm{H}), 3.81$ (s, 3H), 1.32 (s, 9H) ppm; ${ }^{13} \mathrm{C} \mathrm{NMR}\left(\mathrm{CDCl}_{3}\right.$, r.t.): $\delta 162.8,162.2,161.65,161.63,156.8,152.3,151.8,148.1,147.9,135.9,135.7,134.9,134.7$, $129.8,129.73,129.71,129.65,129.61,126.9,121.8,121.7,119.7,117.5,117.4,116.8,115.1$, 55.5, 34.4, $31.3 \mathrm{ppm}$. MS (MALDI-ToF) $\mathrm{m} / \mathrm{z}$ calcd for $\left(\mathrm{C}_{49} \mathrm{H}_{40} \mathrm{O}_{7}\right) 740.8$, found $741.5[\mathrm{M}]^{+}$, $763.8[\mathrm{M}+\mathrm{Na}]^{+}$. 


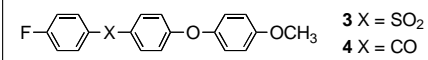

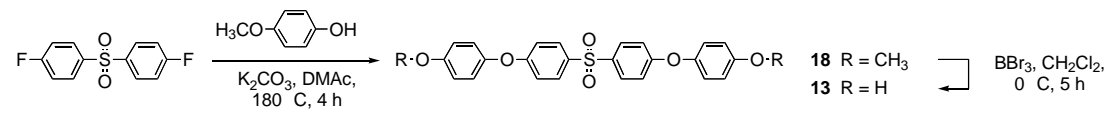

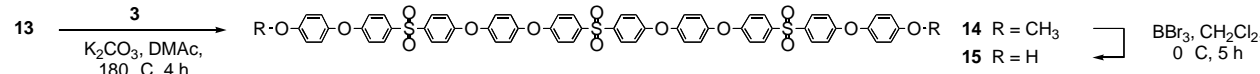

$15 \frac{4}{\stackrel{\mathrm{K}_{2} \mathrm{CO}_{3}, \mathrm{DMAc},}{180 \mathrm{C}, 4 \mathrm{~h}}}$

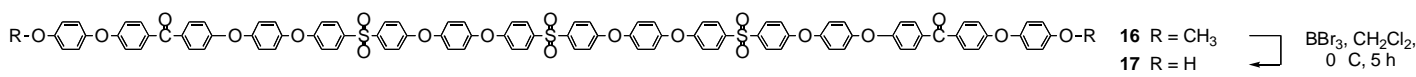
$17 \underset{\mathrm{K}_{2} \mathrm{CO}_{3}, \mathrm{DMAc},}{\longrightarrow}$

R(O- -

S-Scheme 1. Synthesis of Triblock OEK- $b$-OES- $b$-OEK 2
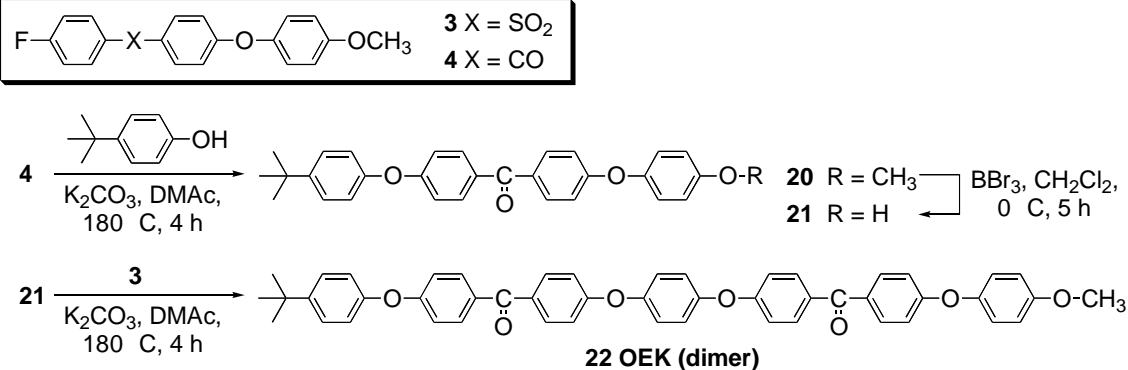

S-Scheme 2. Synthesis of OEK Dimmer 


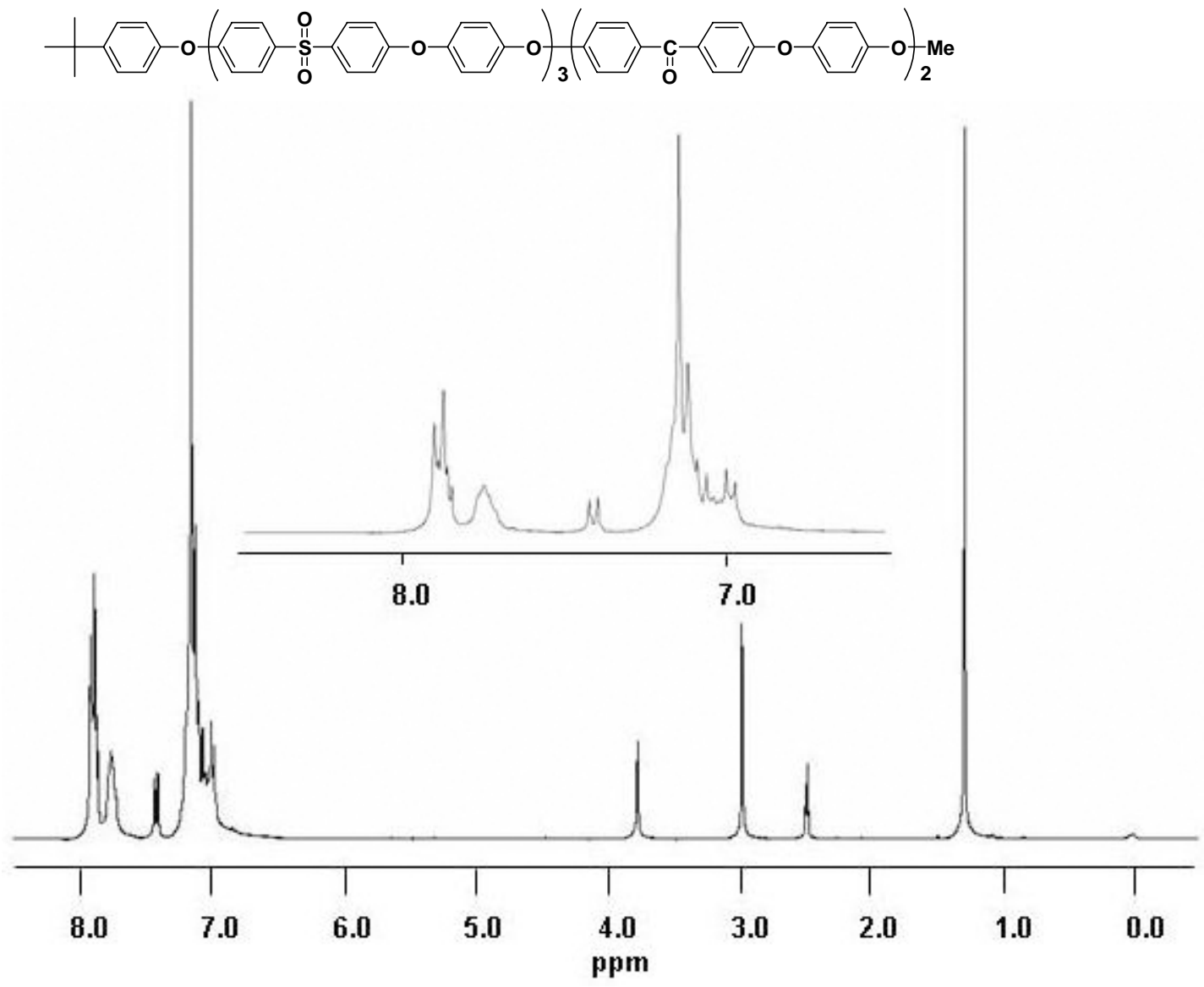

S-Figure 1. ${ }^{1} \mathrm{H}-\mathrm{NMR}$ spectrum of diblock OES- $b$-OEK 1 in DMSO- $d_{6}$ r.t.

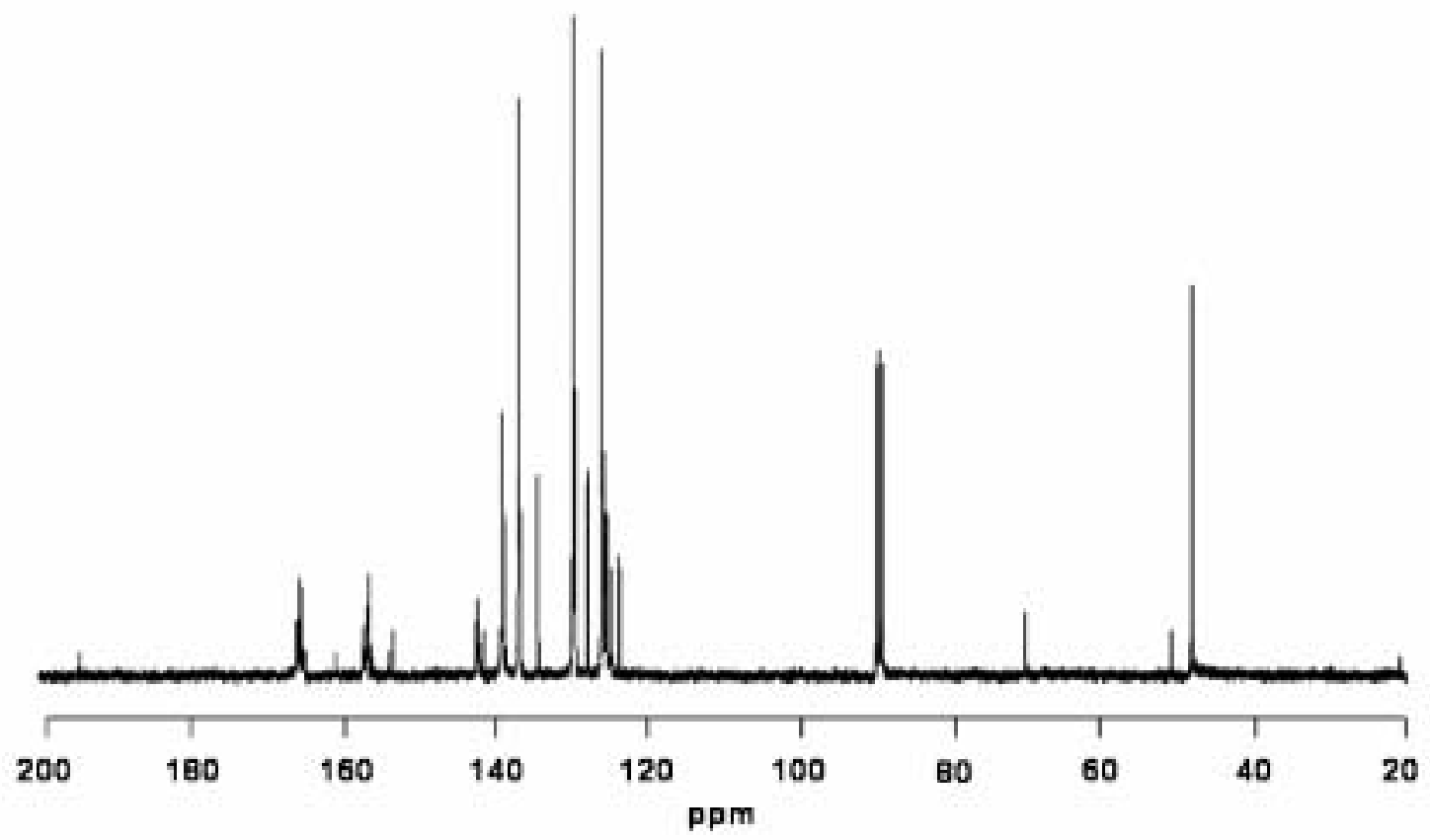

S-Figure 2. ${ }^{13} \mathrm{C}$-NMR spectrum of diblock OES-b-OEK $\mathbf{1}$ in $\mathrm{CDCl}_{3}$ r.t.. 


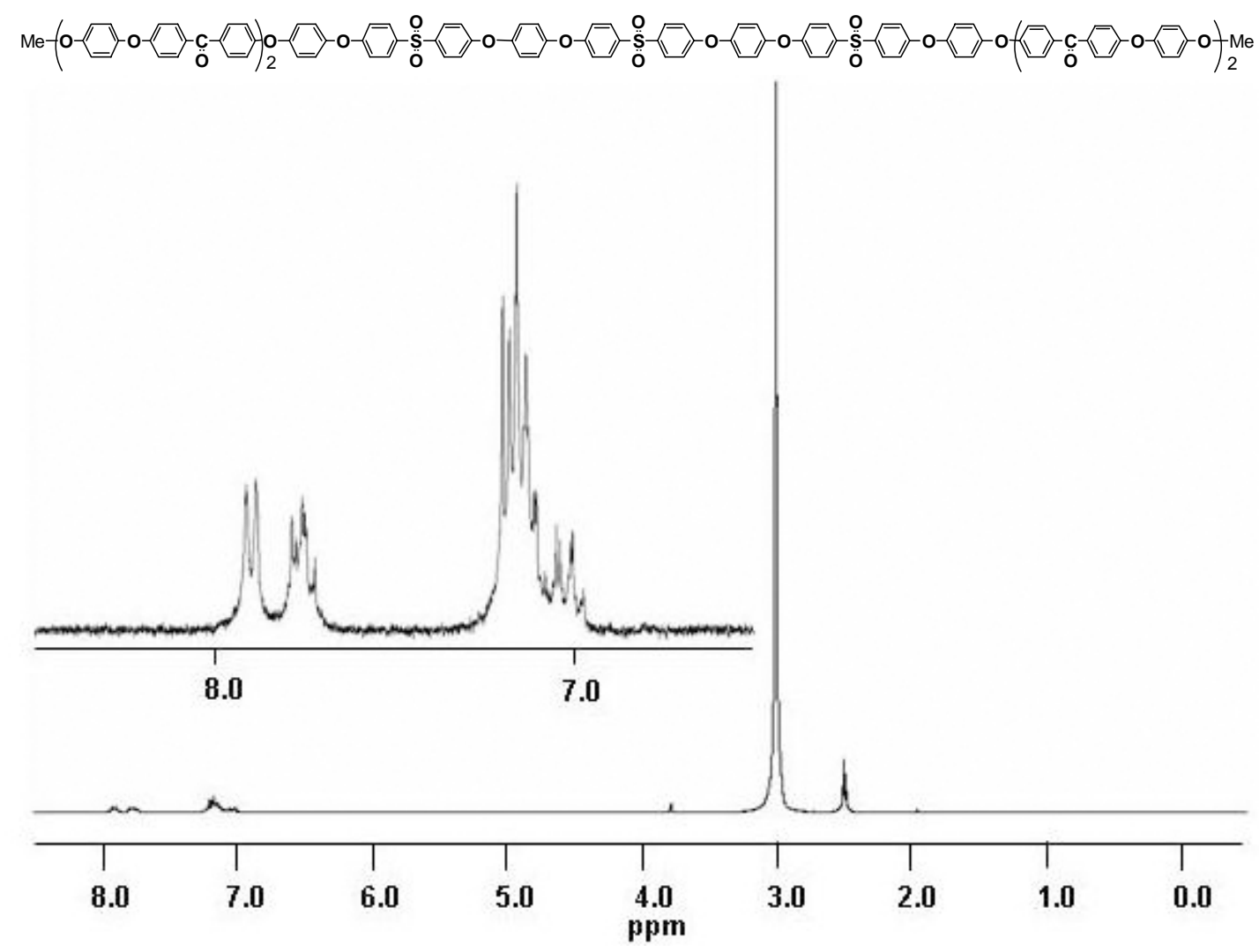

S-Figure 3. ${ }^{1} \mathrm{H}-\mathrm{NMR}$ spectrum of triblock OEK- $b$-OES- $b$-OEK 2 in DMSO- $d_{6}$ at $100{ }^{\circ} \mathrm{C}$.

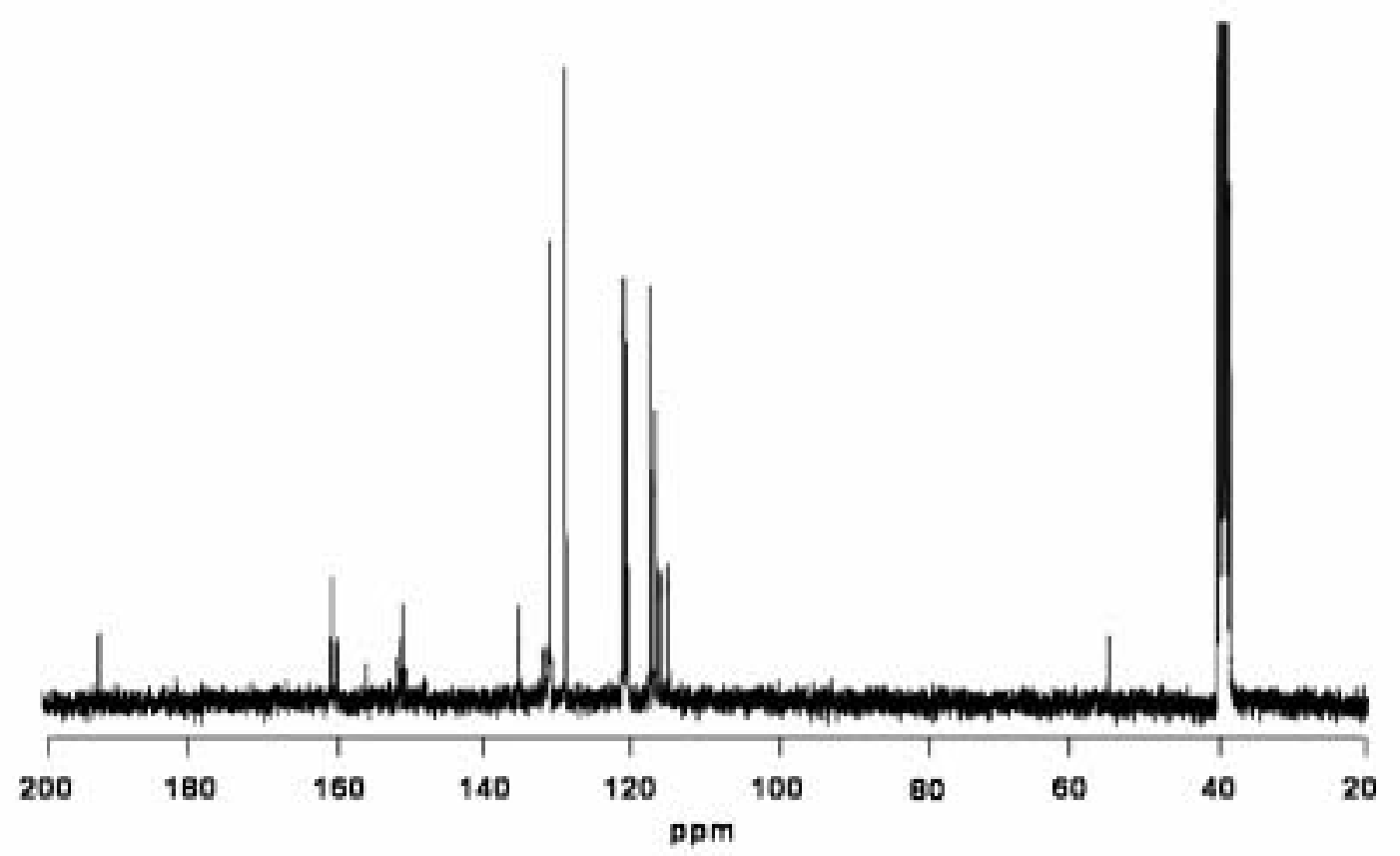

S-Figure 4. ${ }^{1} \mathrm{H}-\mathrm{NMR}$ spectrum of triblock OEK- $b$-OES- $b$-OEK 2 in DMSO- $d_{6}$ at $130{ }^{\circ} \mathrm{C}$. 


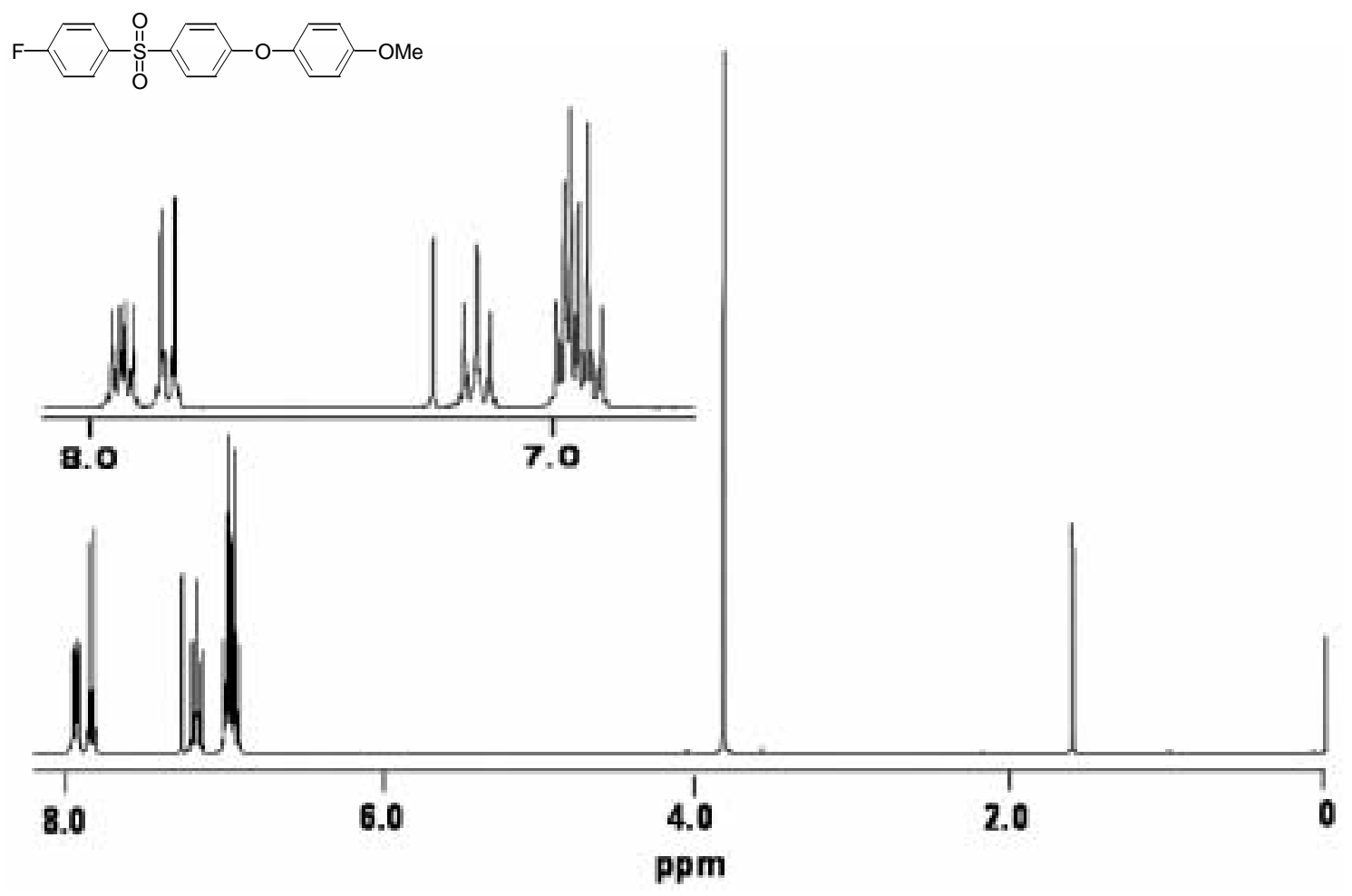

S-Figure 5. ${ }^{1} \mathrm{H}-\mathrm{NMR}$ spectrum of $\mathbf{3}$ in $\mathrm{CDCl}_{3}$ r.t.

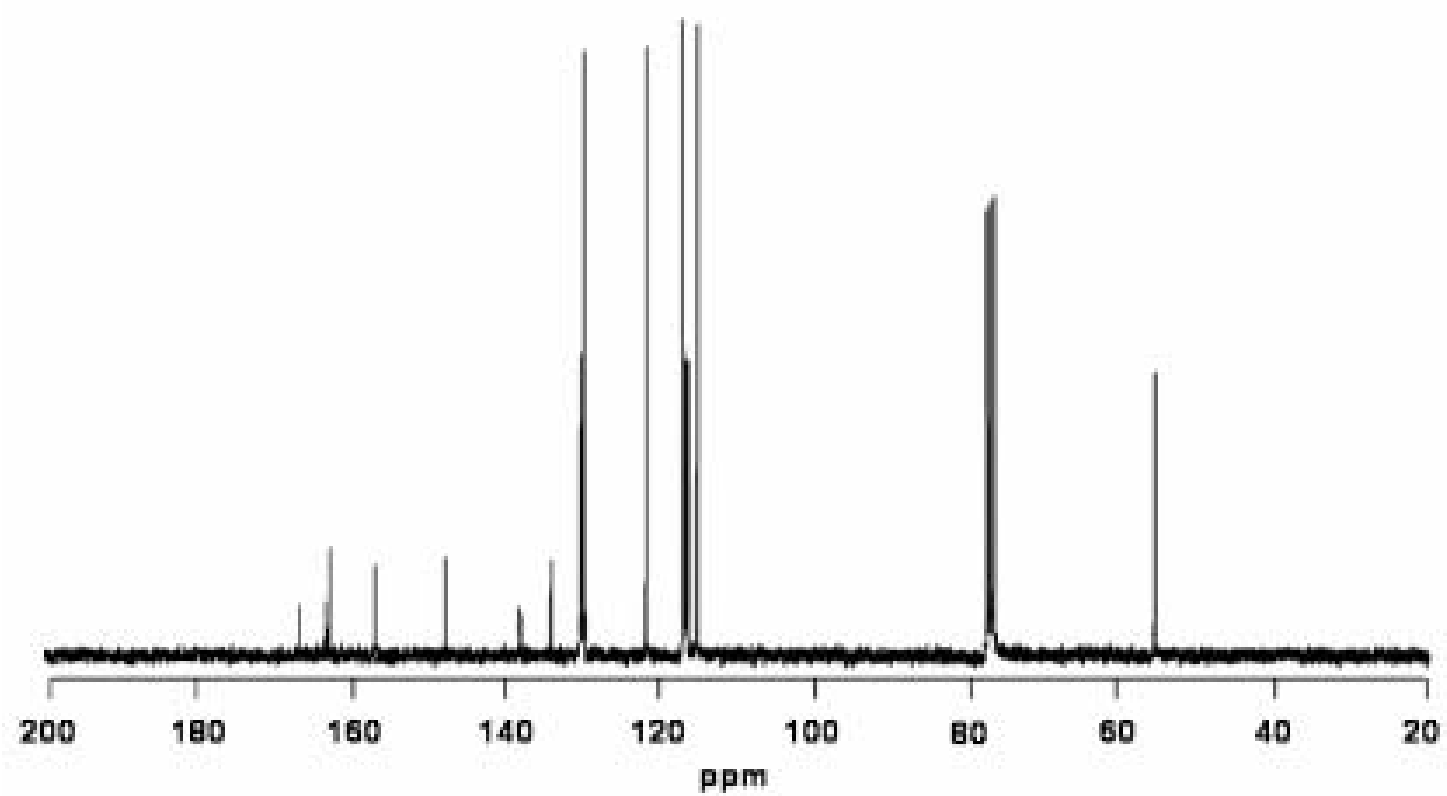

S-Figure 6. ${ }^{1} \mathrm{H}-\mathrm{NMR}$ spectrum of $\mathbf{3}$ in $\mathrm{CDCl}_{3}$ r.t.. 


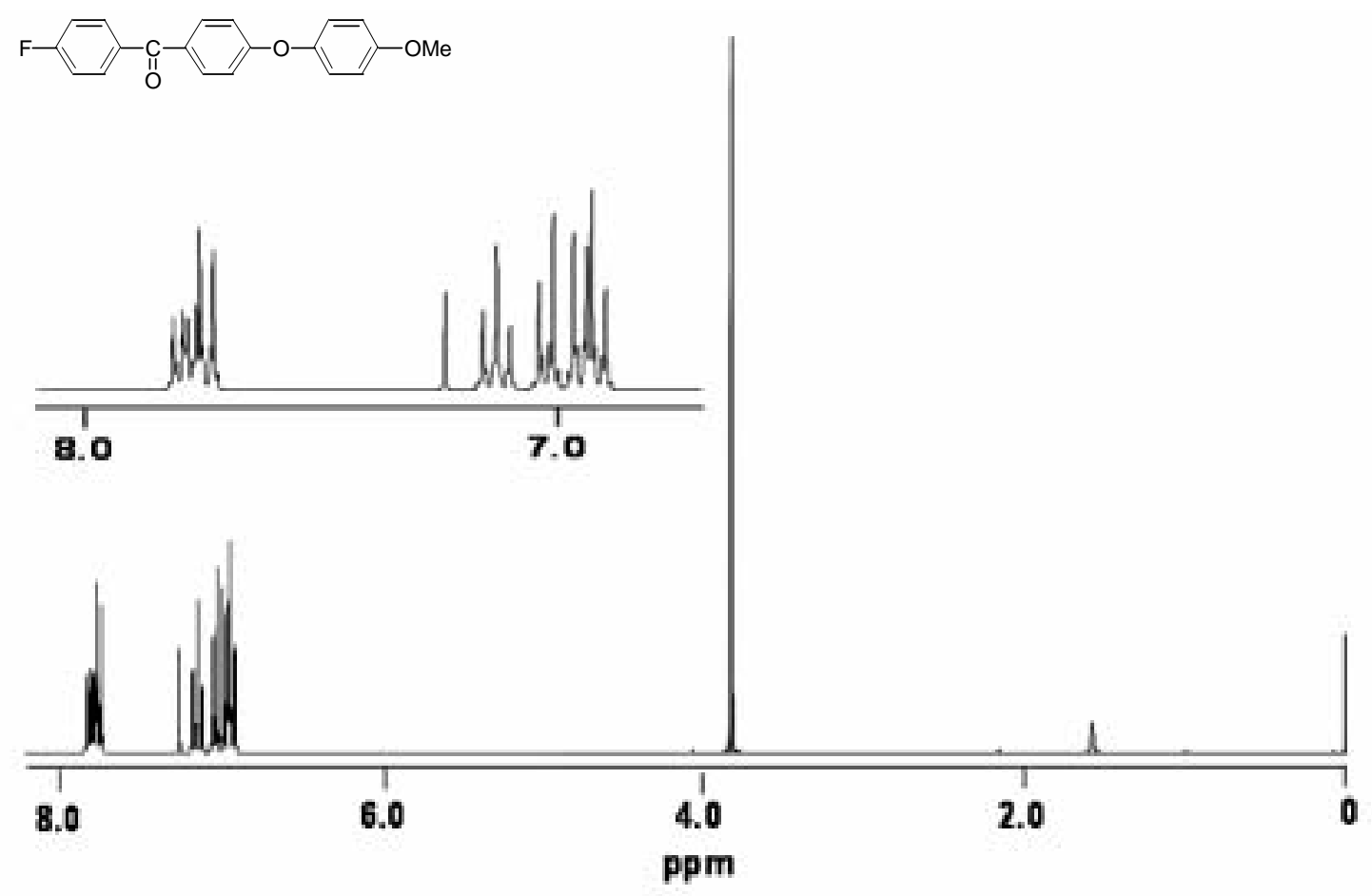

S-Figure 7. ${ }^{1} \mathrm{H}-\mathrm{NMR}$ spectrum of $\mathbf{4}$ in $\mathrm{CDCl}_{3}$ r.t.

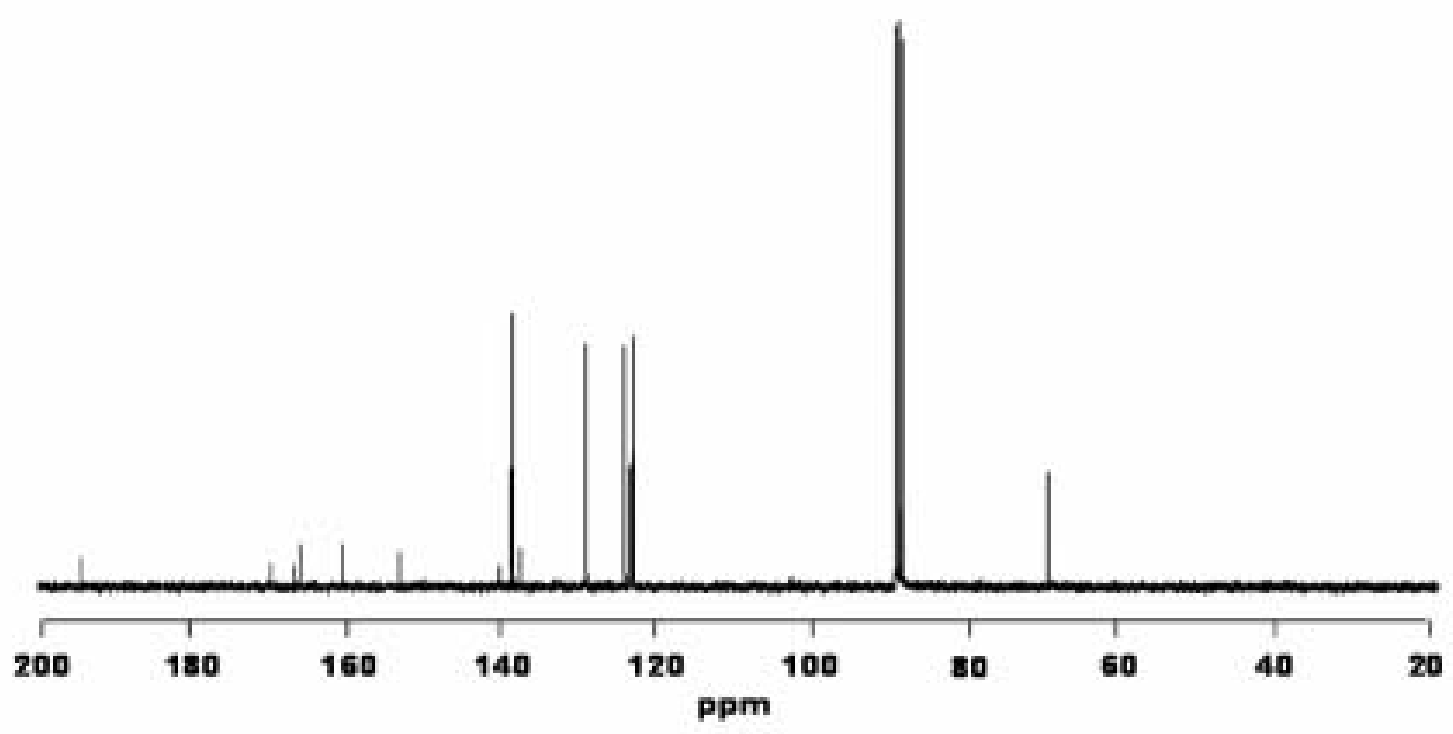

S-Figure 8. ${ }^{1} \mathrm{H}-\mathrm{NMR}$ spectrum of $\mathbf{4}$ in $\mathrm{CDCl}_{3}$ r.t.. 


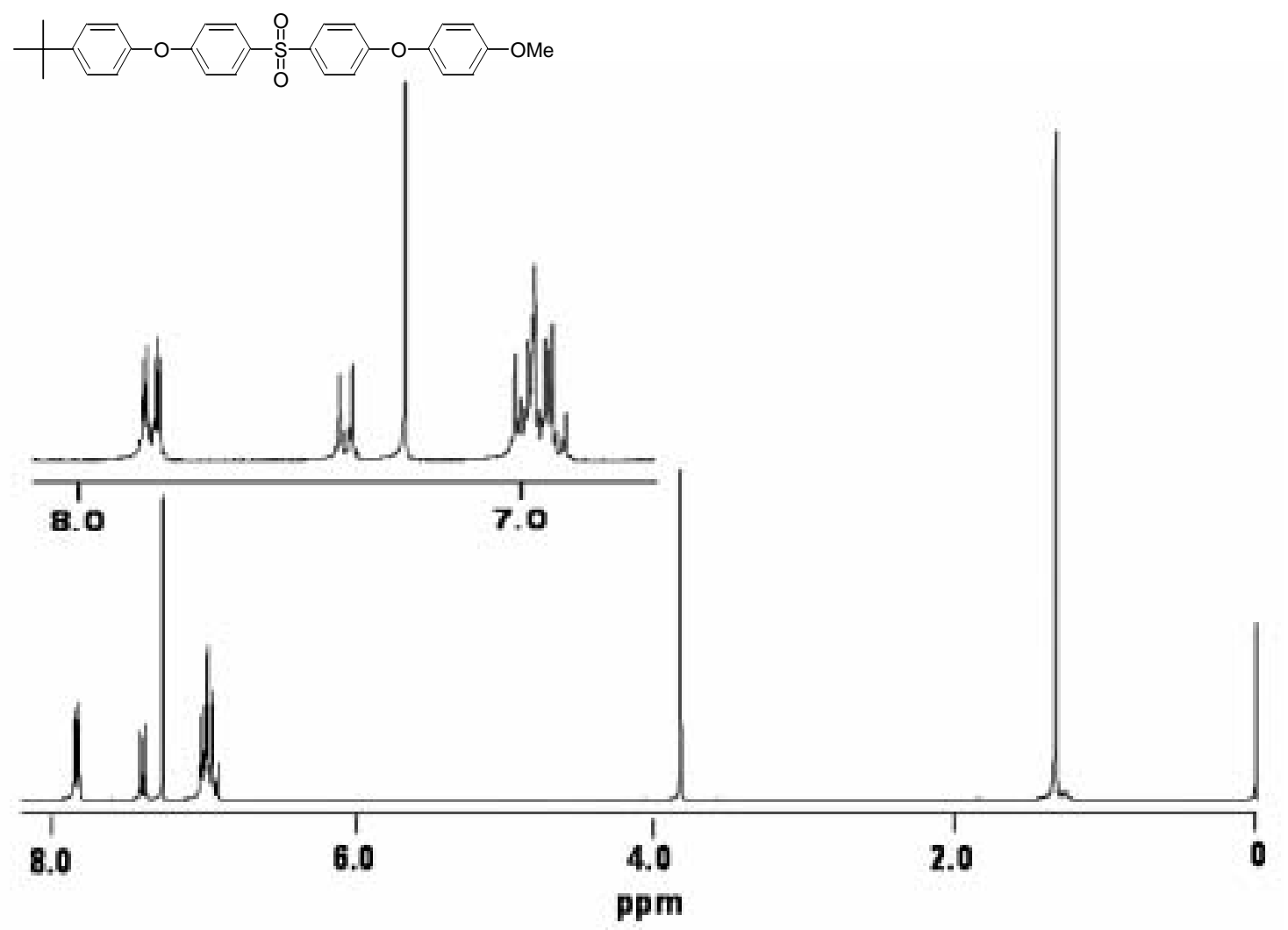

S-Figure 9. ${ }^{1} \mathrm{H}-\mathrm{NMR}$ spectrum of 5 in $\mathrm{CDCl}_{3}$ r.t..

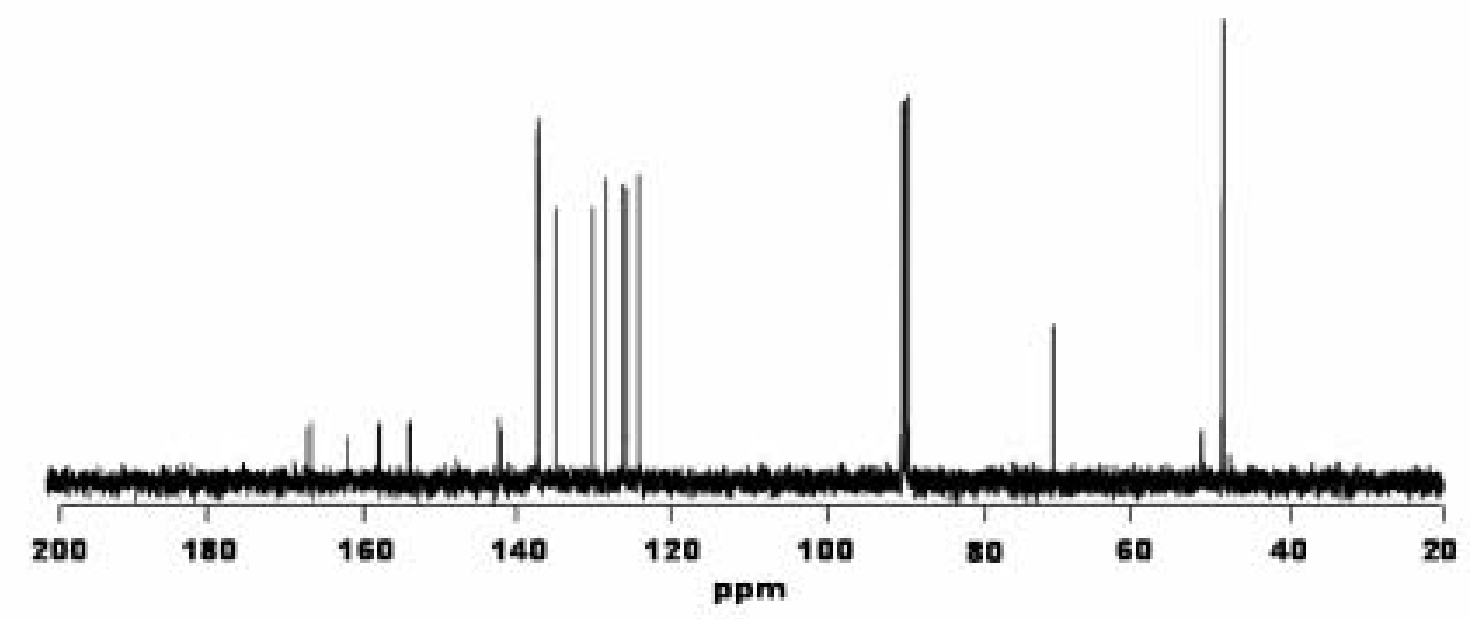

S-Figure 10. ${ }^{13} \mathrm{C}-\mathrm{NMR}$ spectrum of 5 in $\mathrm{CDCl}_{3}$ r.t.. 


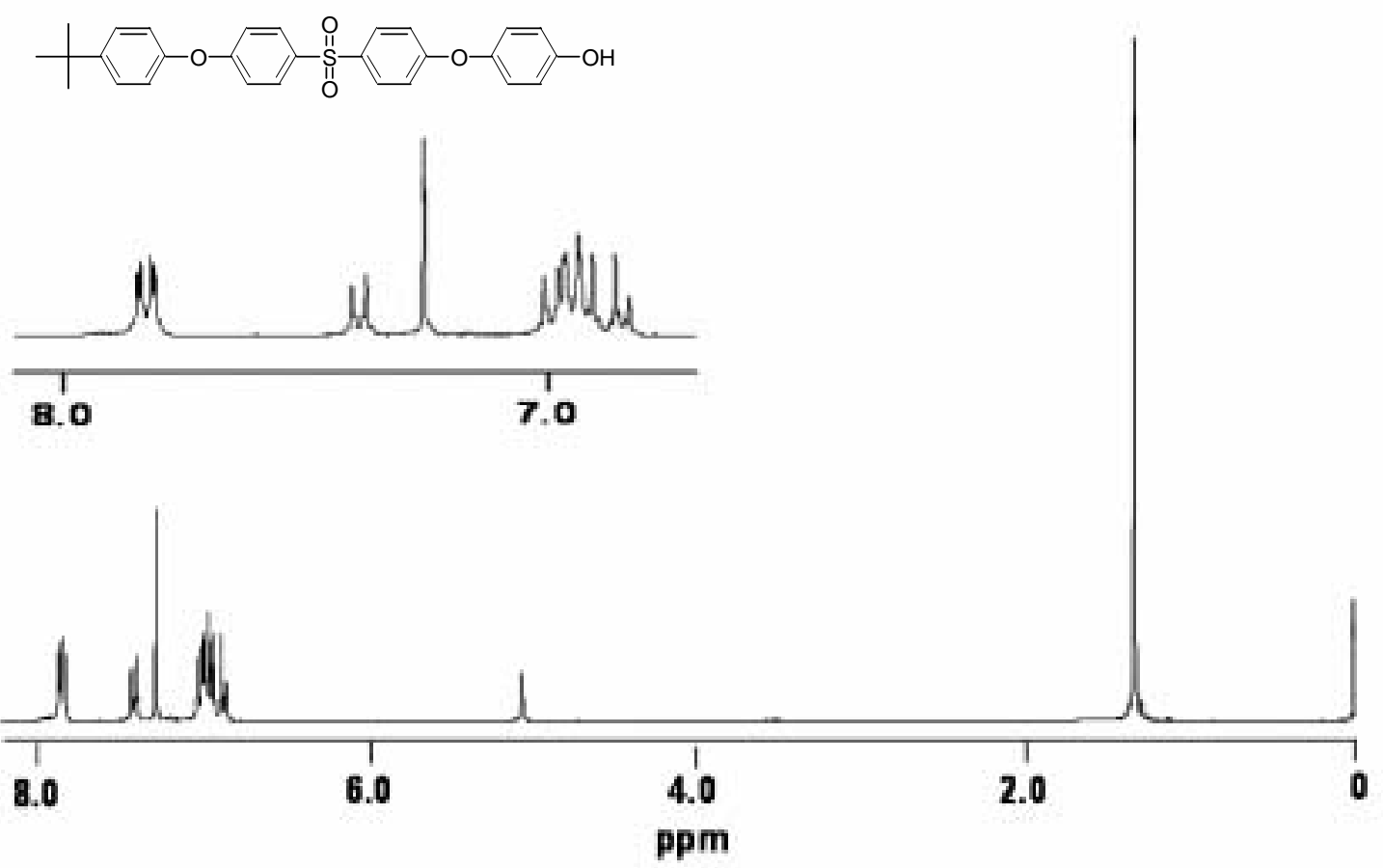

S-Figure 11. ${ }^{1} \mathrm{H}-\mathrm{NMR}$ spectrum of $\mathbf{6}$ in $\mathrm{CDCl}_{3}$ r.t..

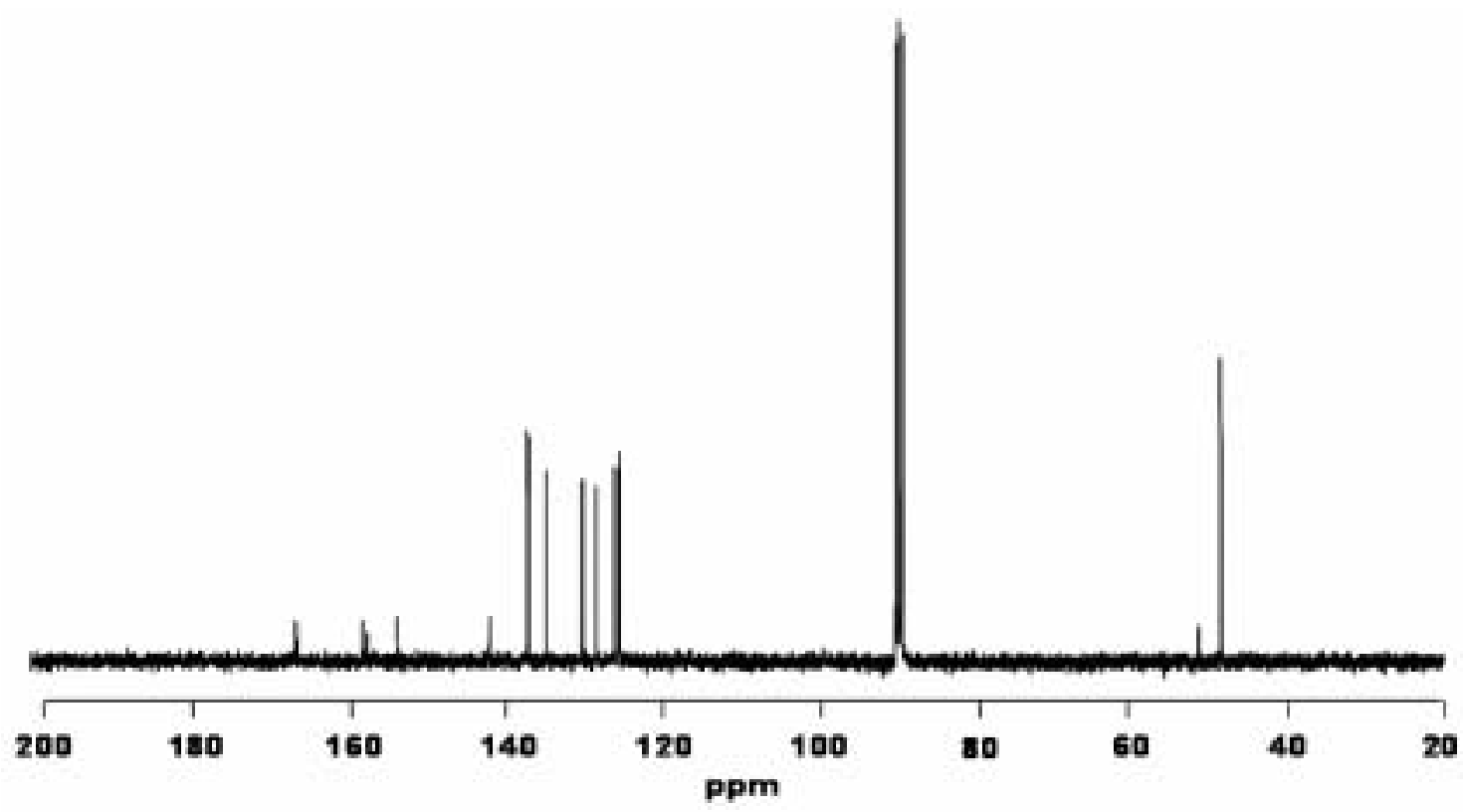

S-Figure 12. ${ }^{13} \mathrm{C}-\mathrm{NMR}$ spectrum of 6 in $\mathrm{CDCl}_{3}$ r.t.. 


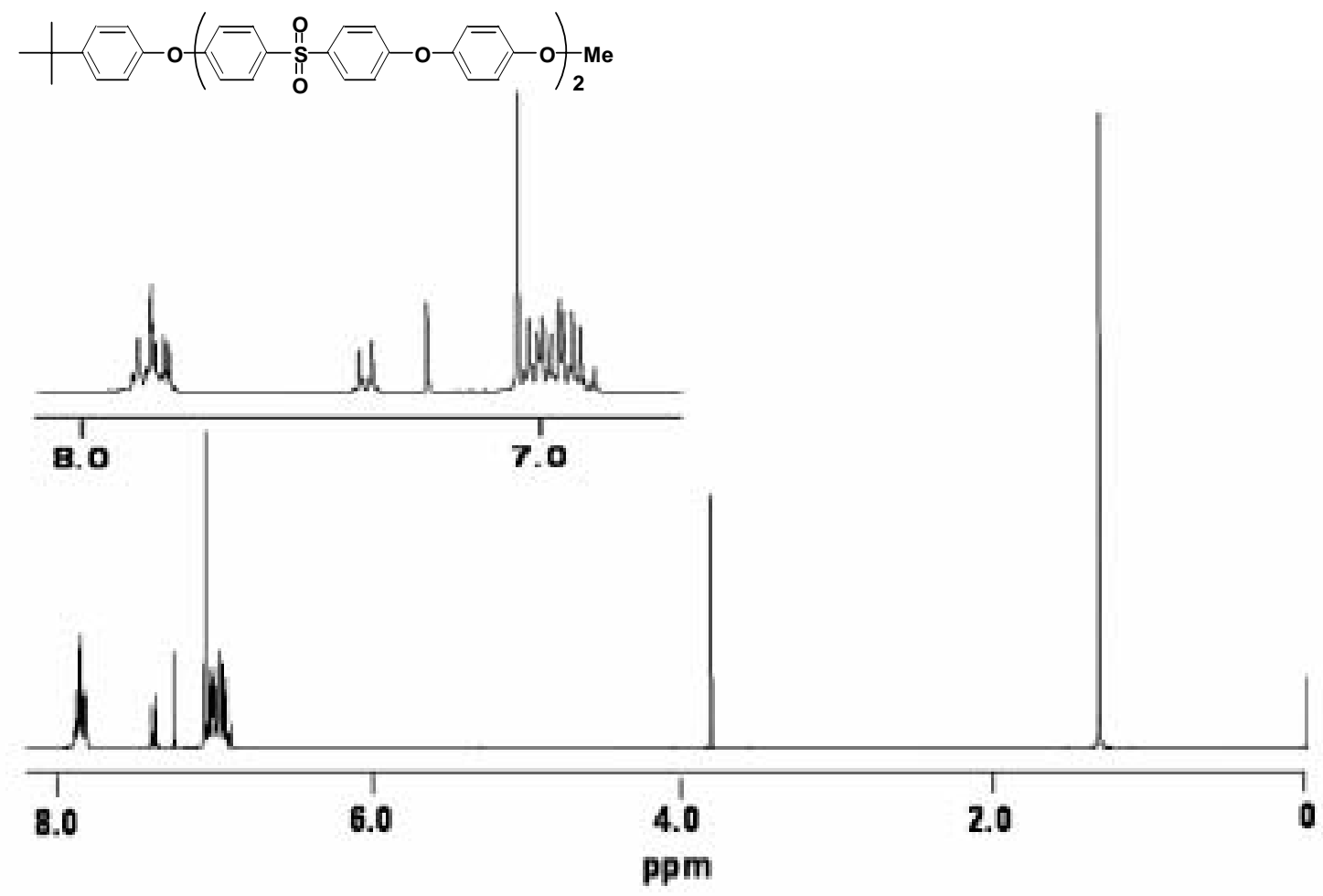

S-Figure 13. ${ }^{1} \mathrm{H}-\mathrm{NMR}$ spectrum of $\mathbf{7}$ in $\mathrm{CDCl}_{3}$ r.t..

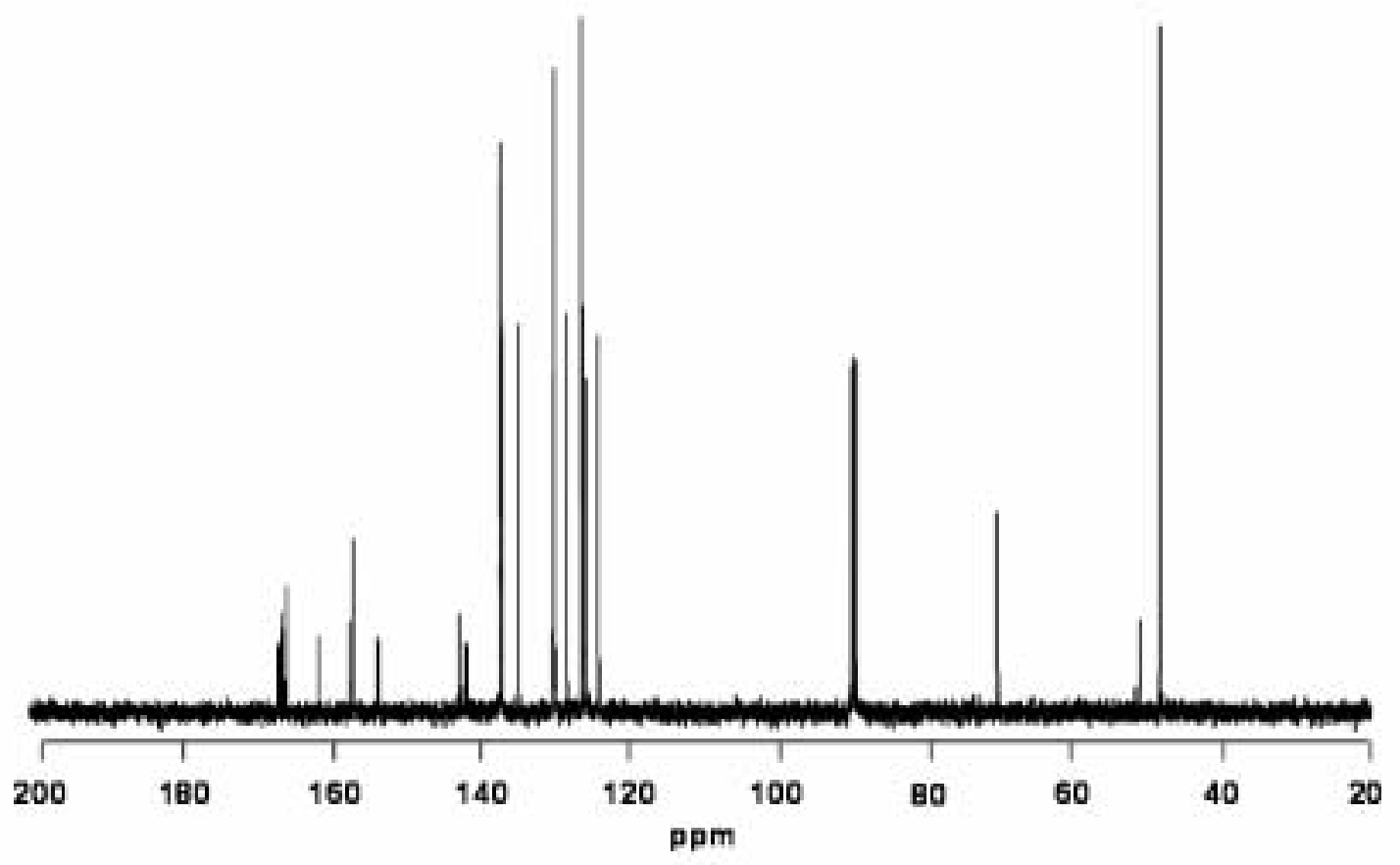

S-Figure 14. ${ }^{13} \mathrm{C}$-NMR spectrum of $\mathbf{7}$ in $\mathrm{CDCl}_{3}$ r.t.. 


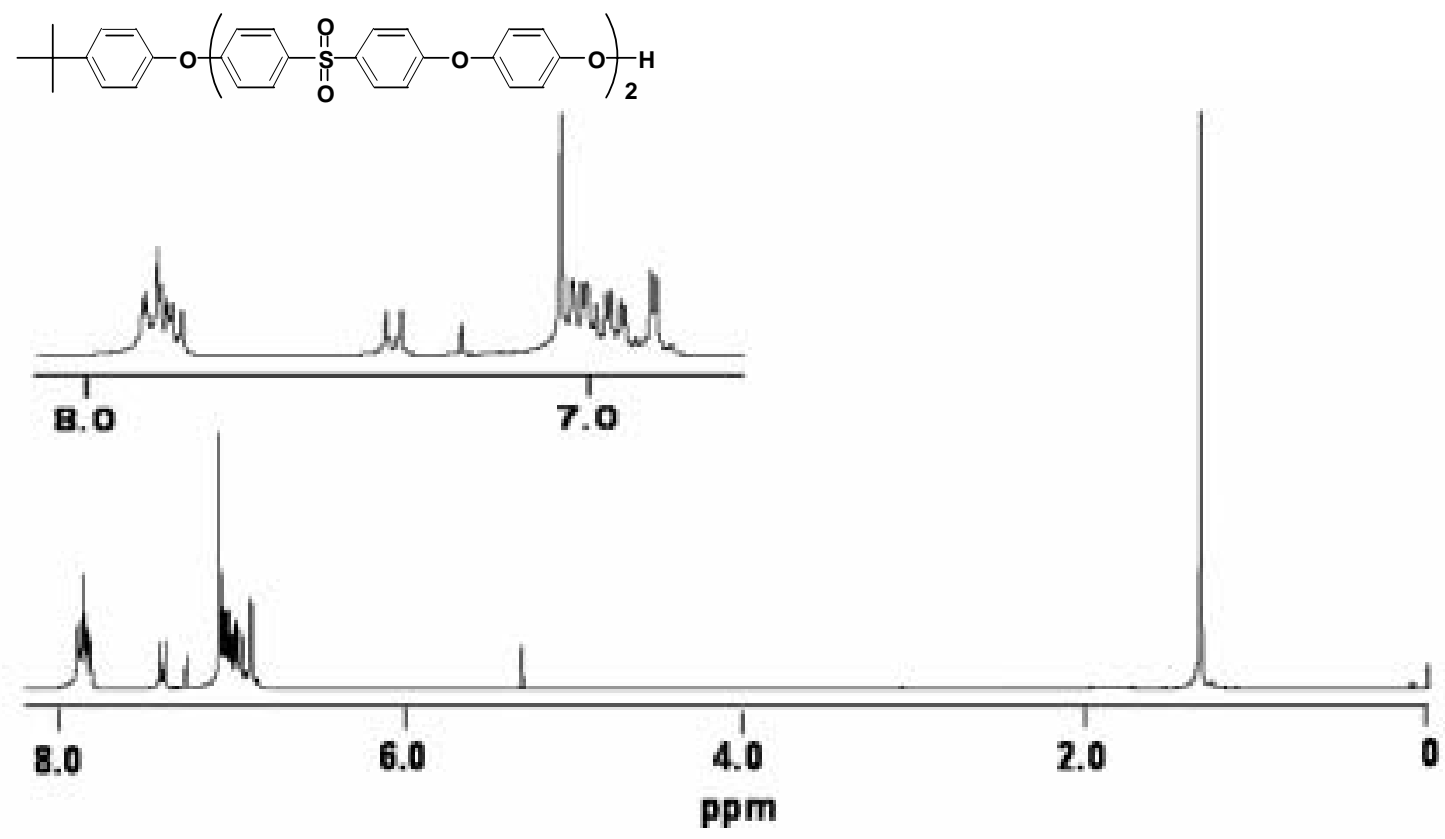

S-Figure 15. ${ }^{1} \mathrm{H}-\mathrm{NMR}$ spectrum of $\mathbf{8}$ in $\mathrm{CDCl}_{3}$ r.t..

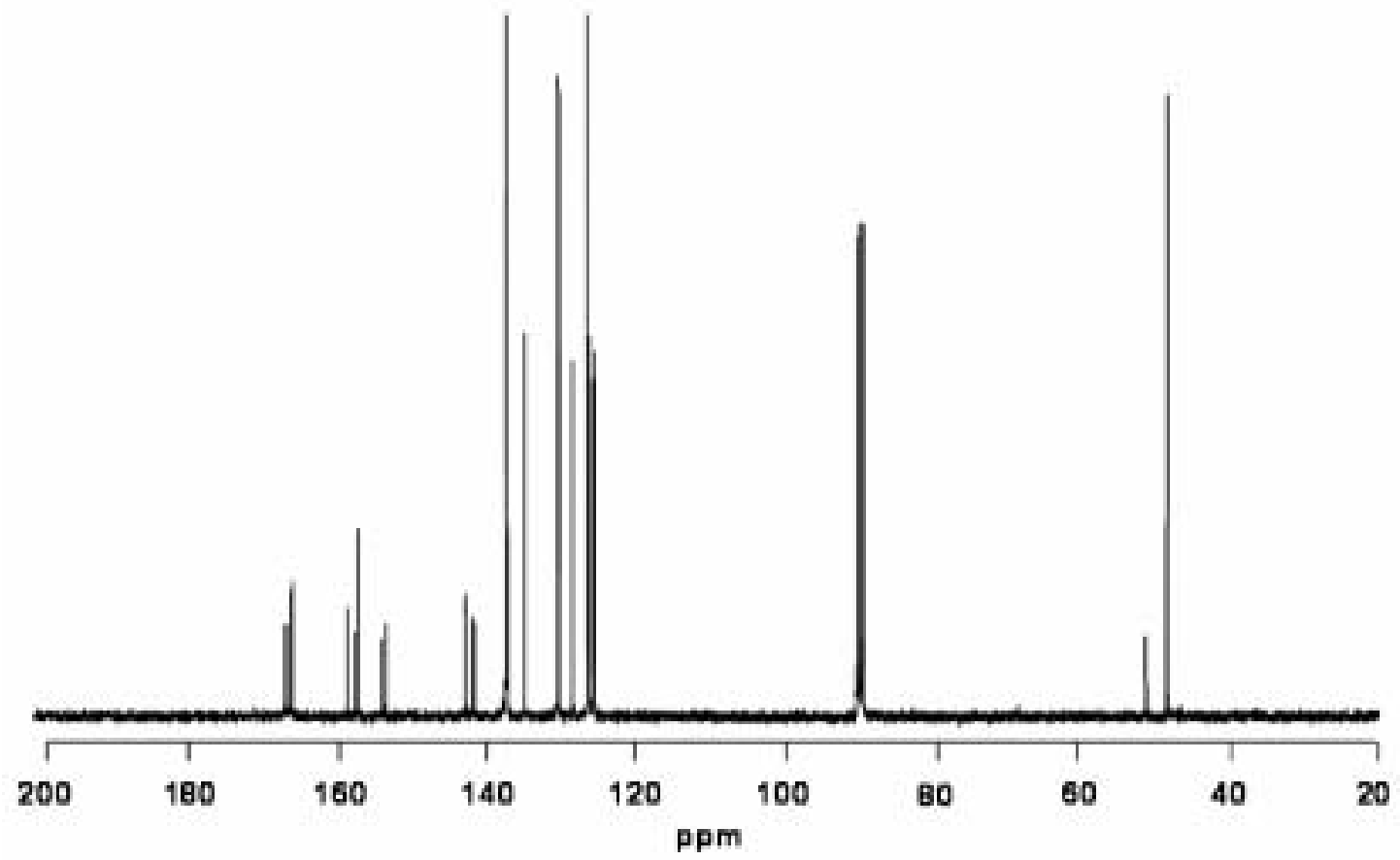

S-Figure 16. ${ }^{13} \mathrm{C}-\mathrm{NMR}$ spectrum of $\mathbf{8}$ in $\mathrm{CDCl}_{3}$ r.t.. 


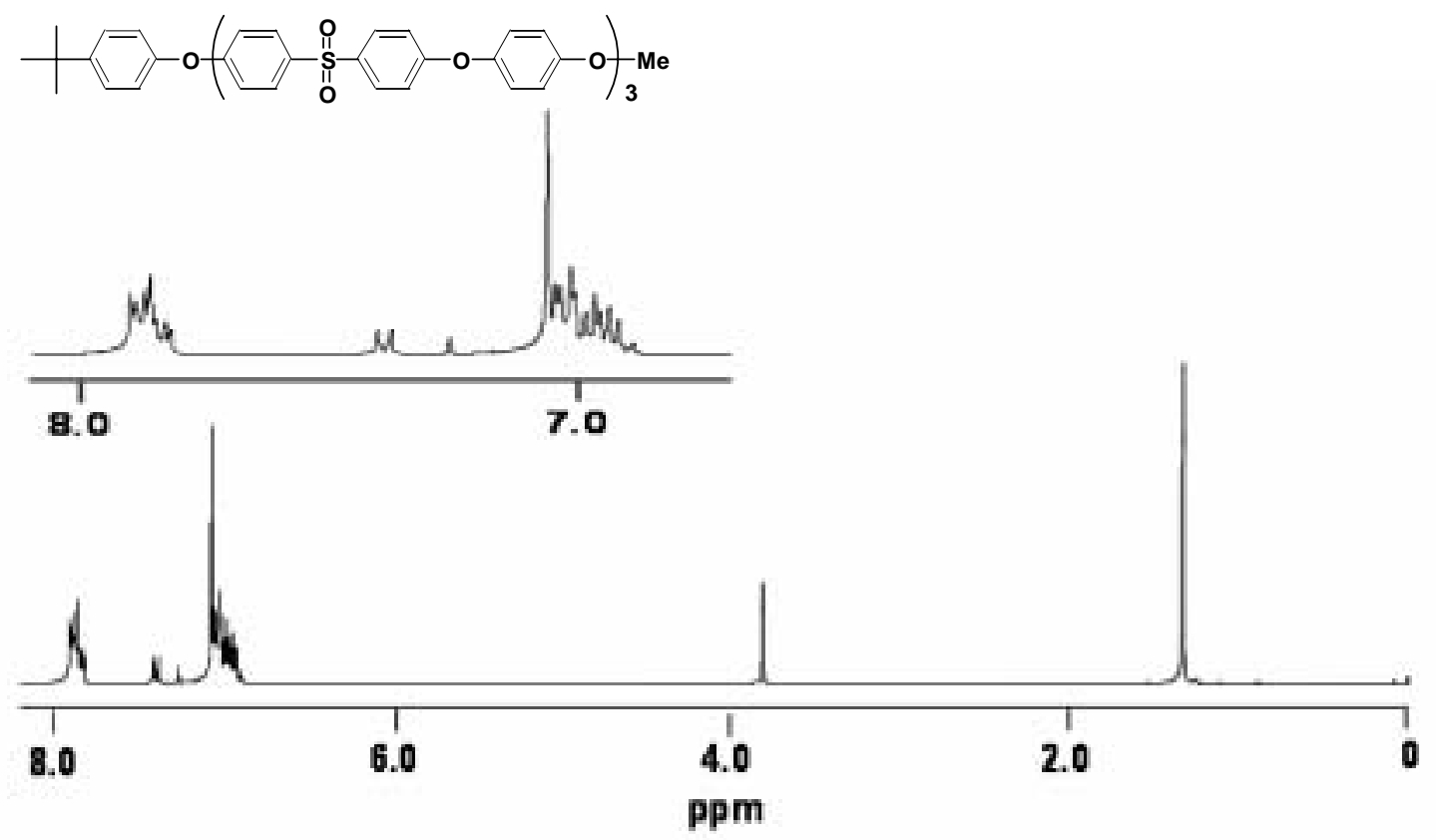

S-Figure 17. ${ }^{1} \mathrm{H}-\mathrm{NMR}$ spectrum of 9 in $\mathrm{CDCl}_{3}$ r.t..

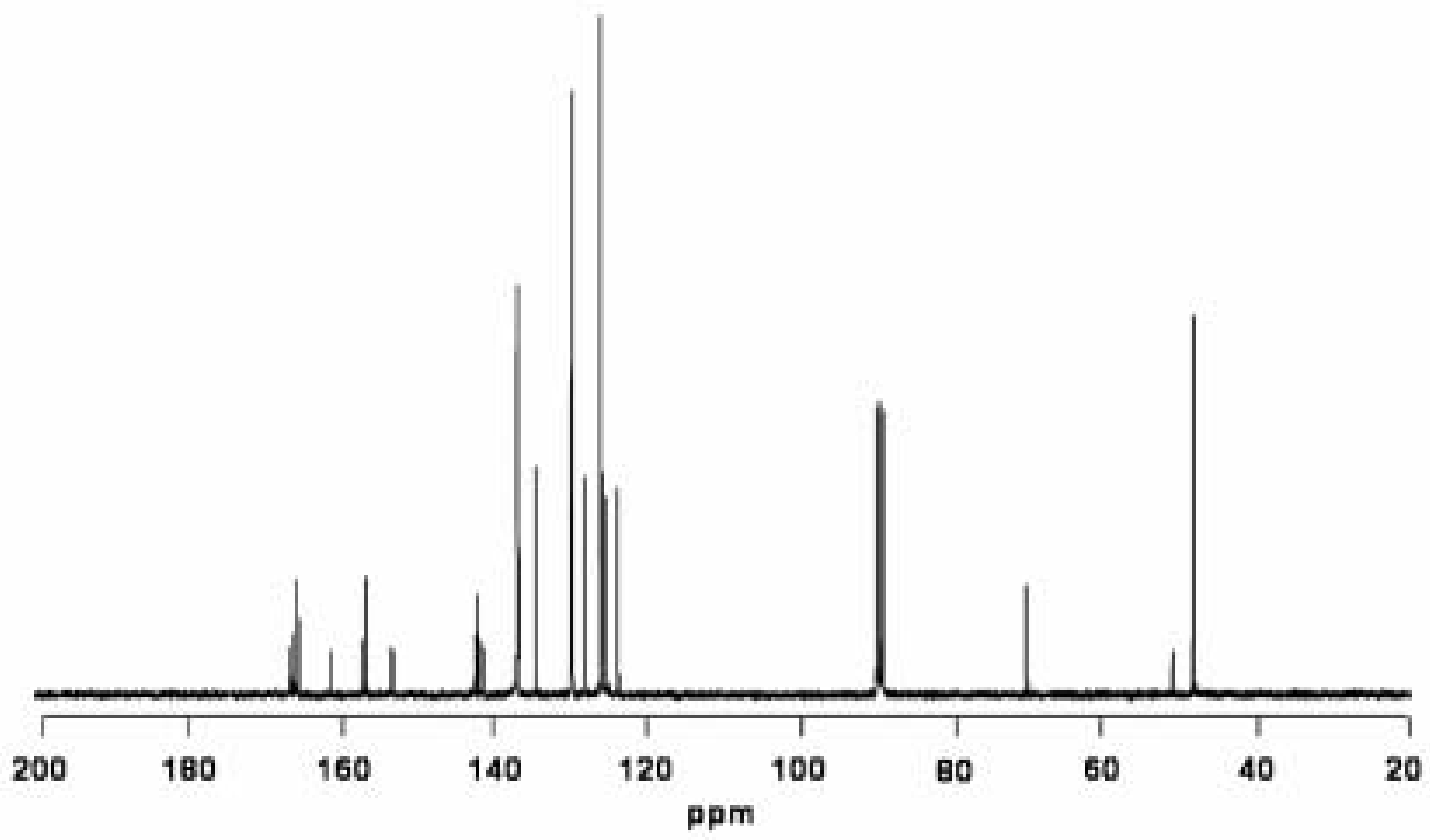

S-Figure 18. ${ }^{13} \mathrm{C}$-NMR spectrum of 9 in $\mathrm{CDCl}_{3}$ r.t.. 


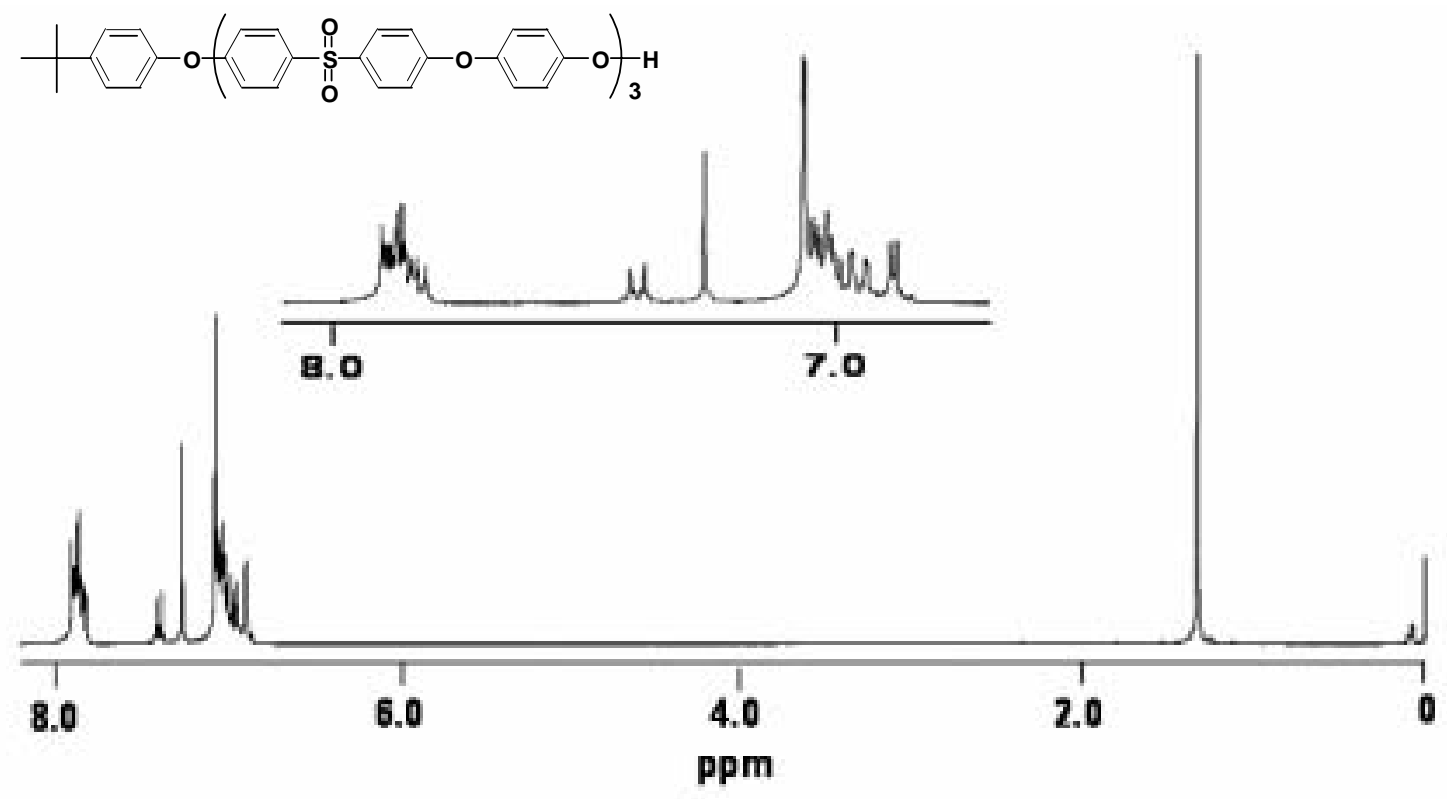

S-Figure 19. ${ }^{1} \mathrm{H}-\mathrm{NMR}$ spectrum of $\mathbf{1 0}$ in $\mathrm{CDCl}_{3}$ r.t..

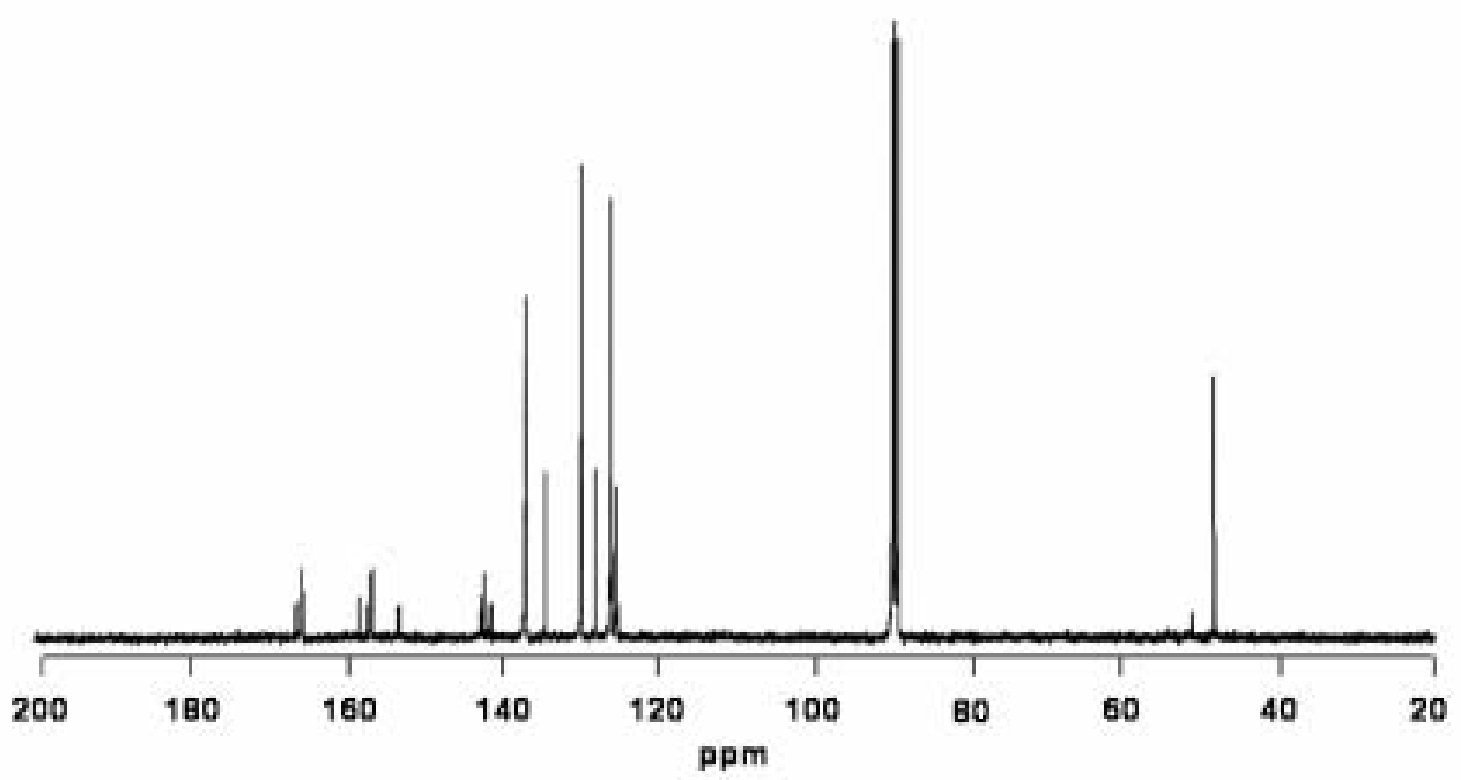

S-Figure 20. ${ }^{13} \mathrm{C}$-NMR spectrum of $\mathbf{1 0}$ in $\mathrm{CDCl}_{3}$ r.t.. 


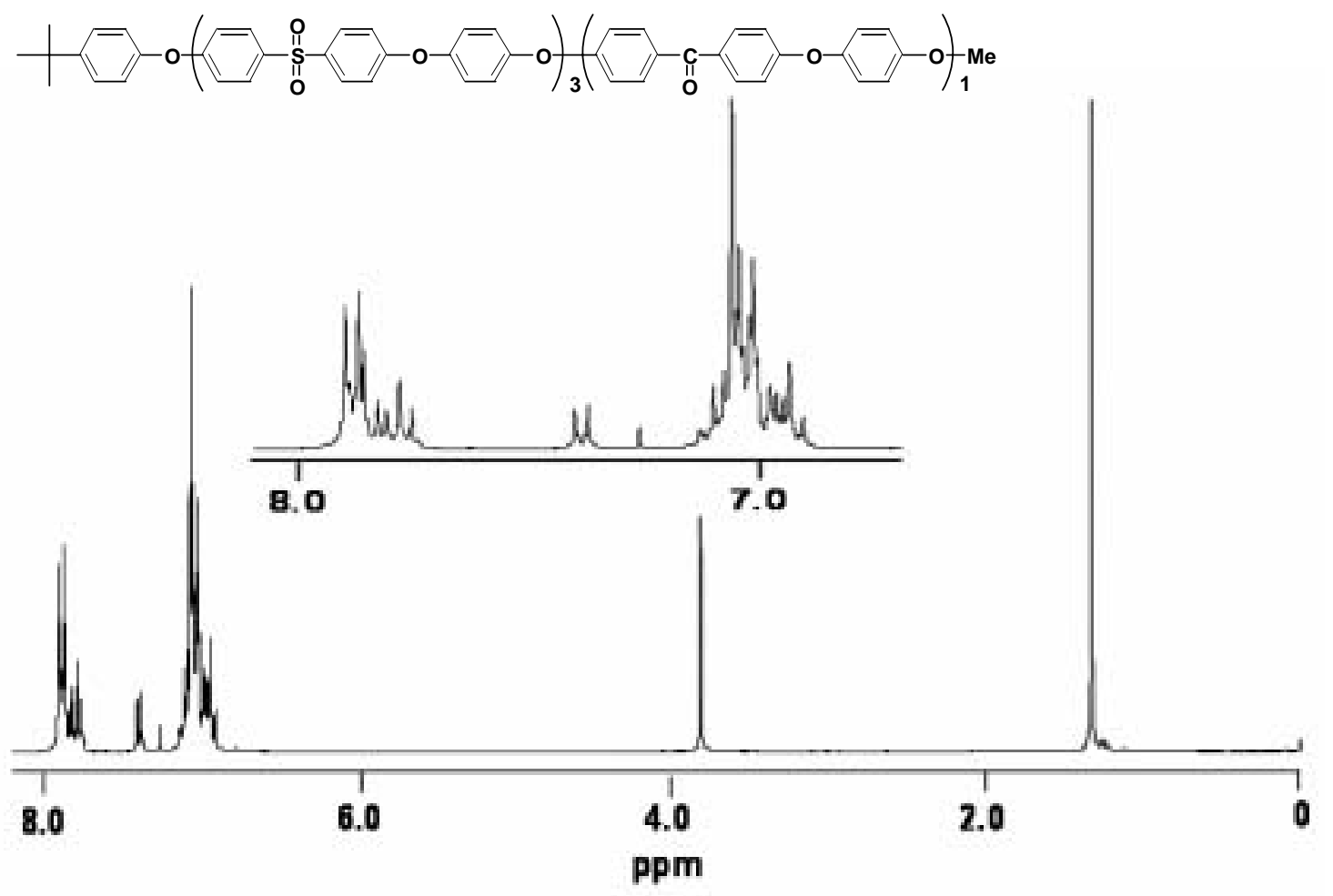

S-Figure 21. ${ }^{1} \mathrm{H}-\mathrm{NMR}$ spectrum of $\mathbf{1 1}$ in $\mathrm{CDCl}_{3}$ r.t..

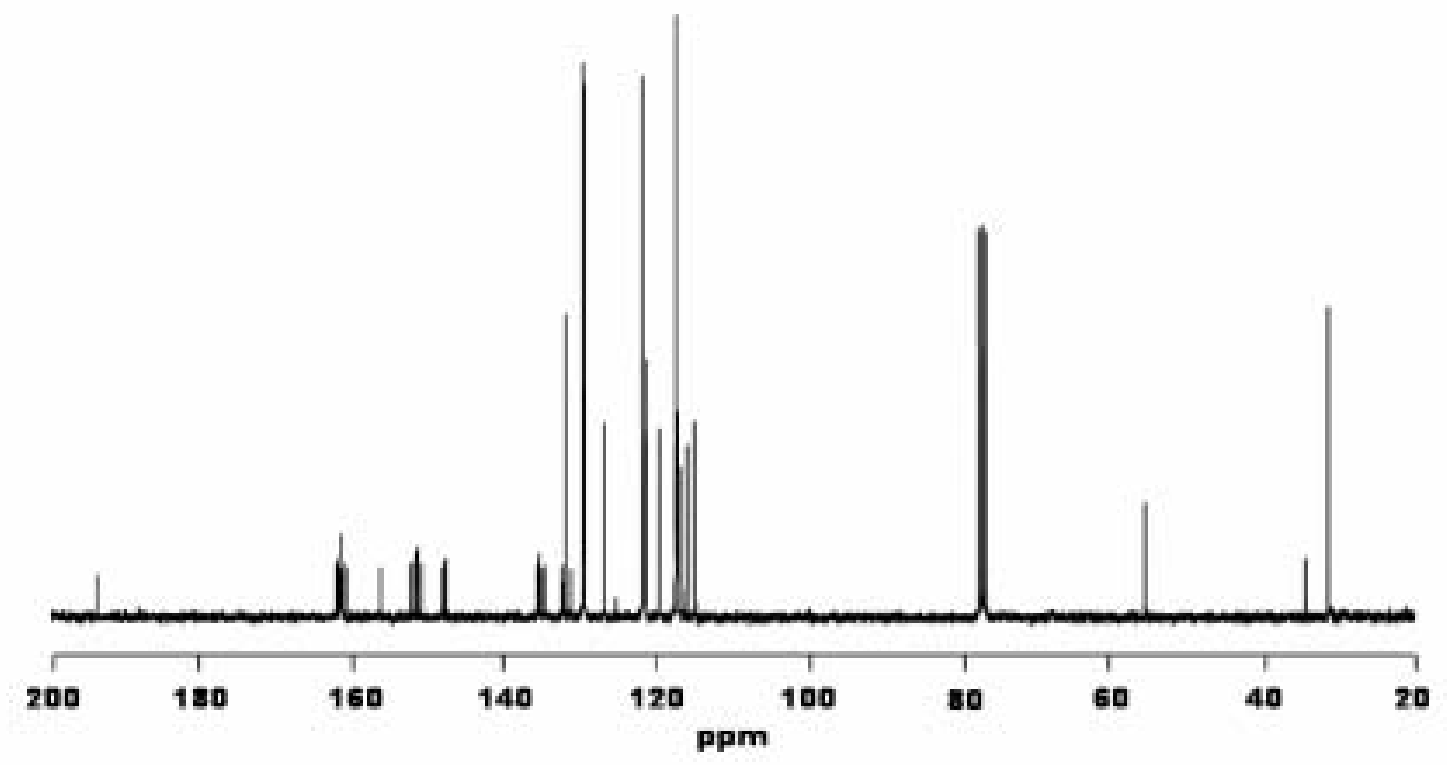

S-Figure 22. ${ }^{13} \mathrm{C}$-NMR spectrum of $\mathbf{1 1}$ in $\mathrm{CDCl}_{3}$ r.t.. 


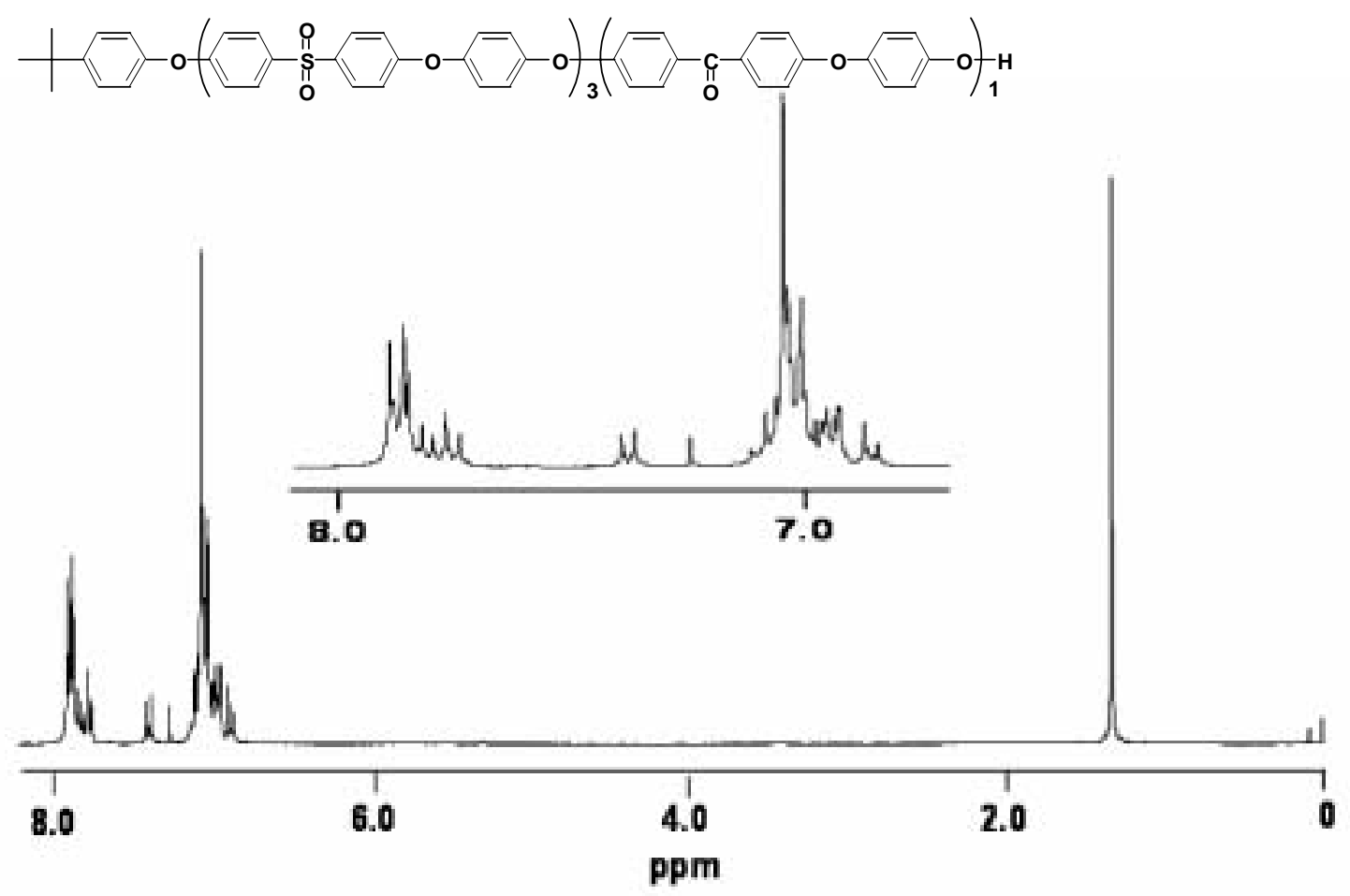

S-Figure 23. ${ }^{1} \mathrm{H}-\mathrm{NMR}$ spectrum of $\mathbf{1 2}$ in $\mathrm{CDCl}_{3}$ r.t. .

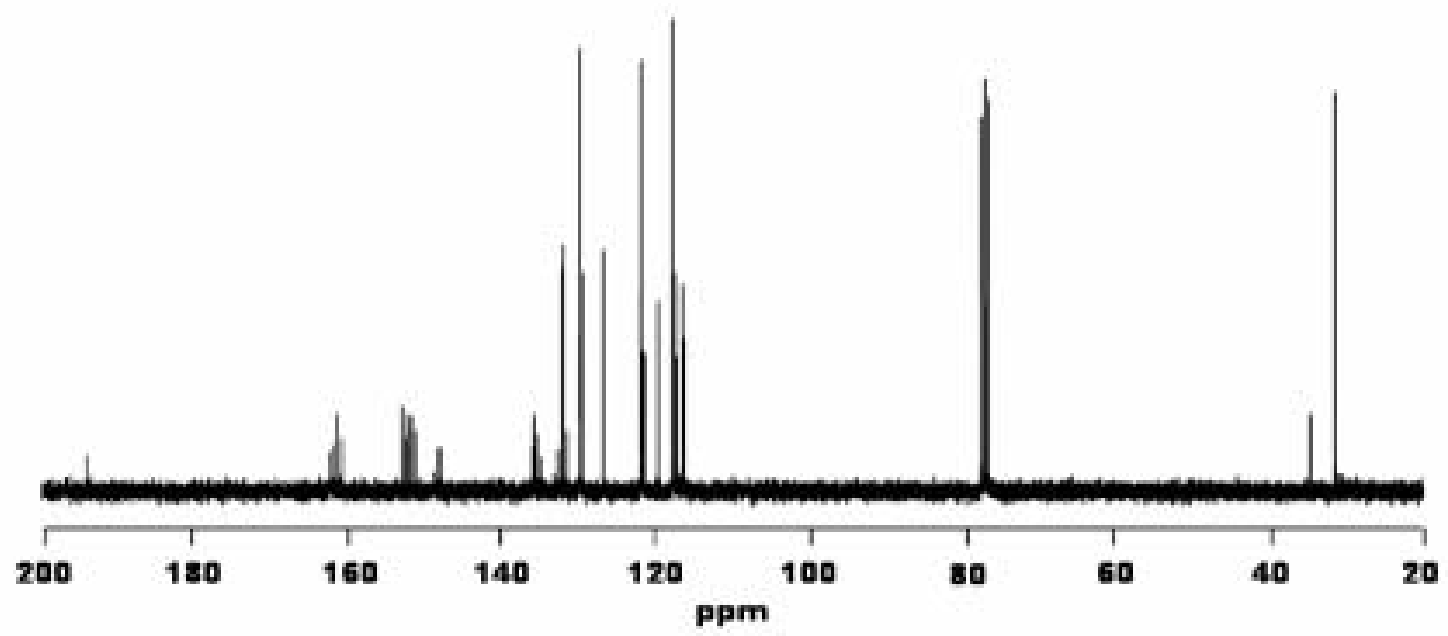

S-Figure 24. ${ }^{13} \mathrm{C}-\mathrm{NMR}$ spectrum of $\mathbf{1 2}$ in $\mathrm{CDCl}_{3}$ r.t.. 


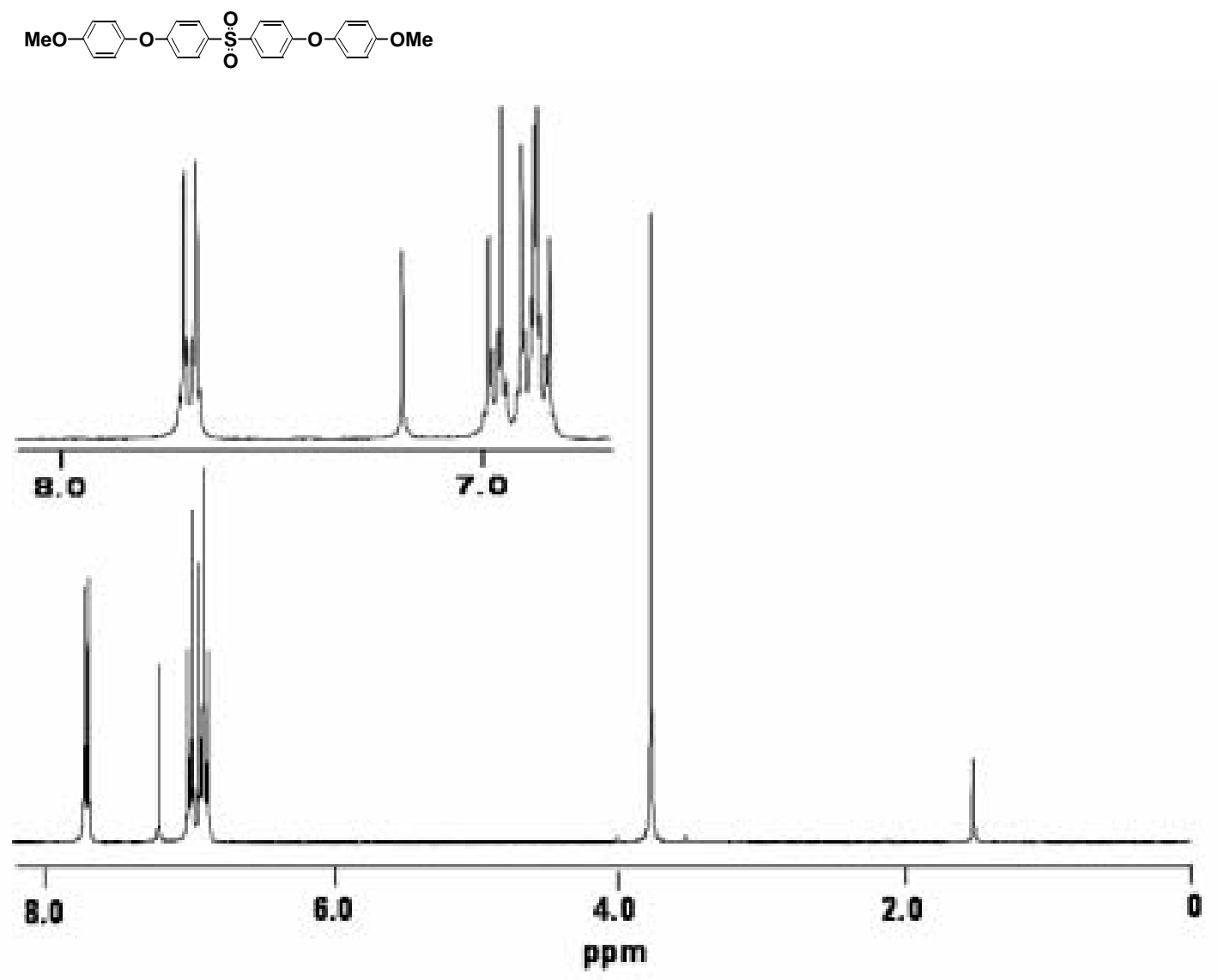

S-Figure 25. ${ }^{1} \mathrm{H}-\mathrm{NMR}$ spectrum of $\mathbf{1 8}$ in $\mathrm{CDCl}_{3}$ r.t..

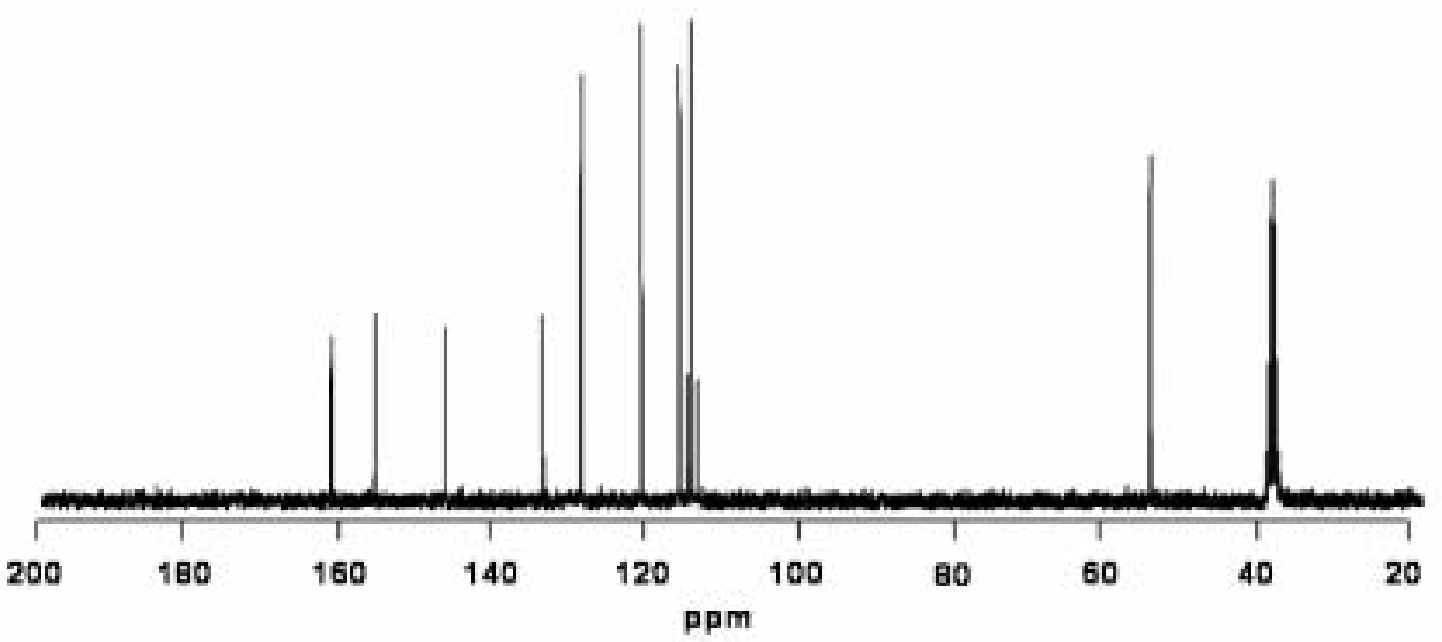

S-Figure 26. ${ }^{13} \mathrm{C}-\mathrm{NMR}$ spectrum of $\mathbf{1 8}$ in DMSO- $d_{6}$ r.t.. 


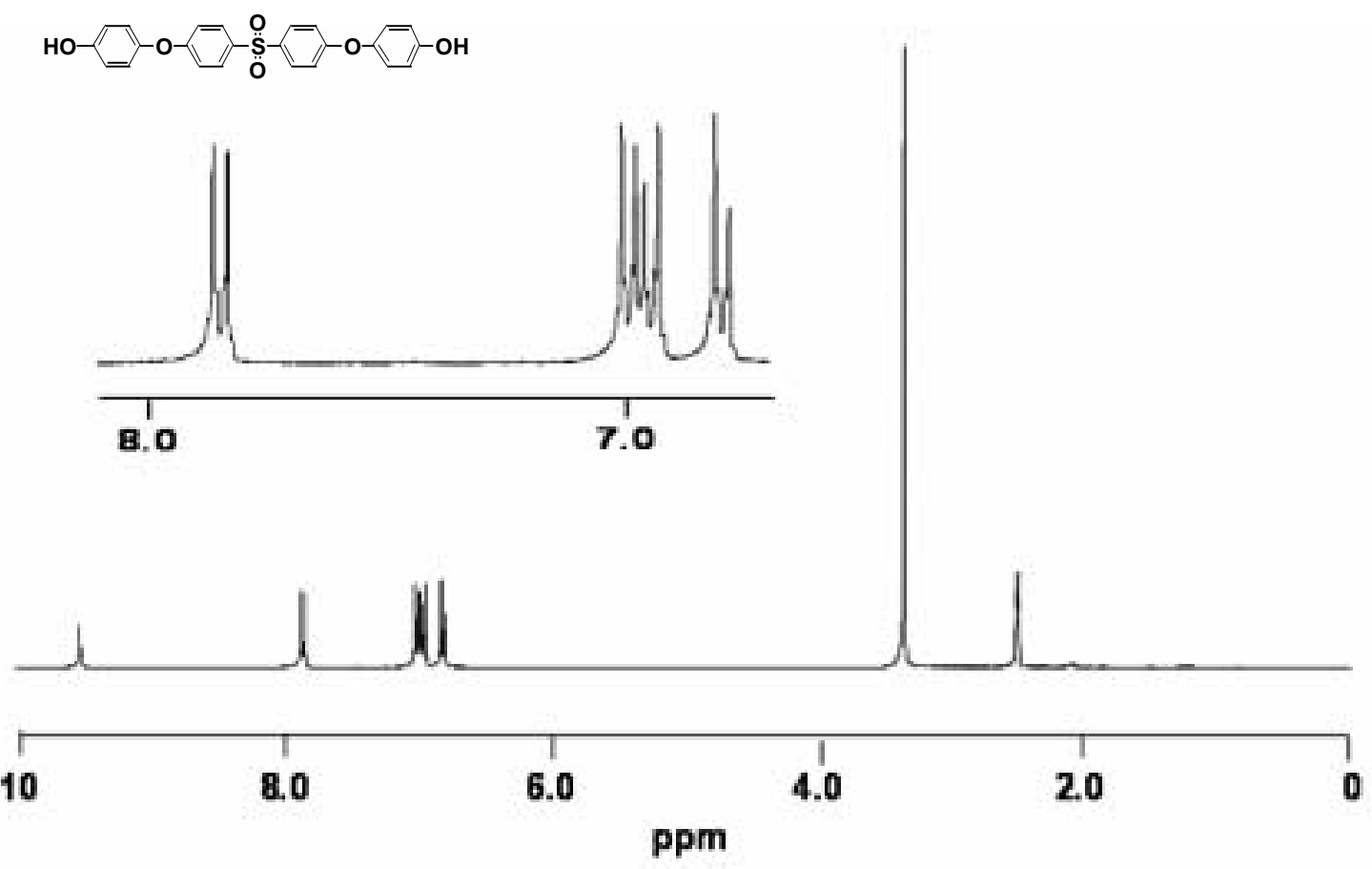

S-Figure 27. ${ }^{1} \mathrm{H}-\mathrm{NMR}$ spectrum of $\mathbf{1 3}$ in DMSO- $d_{6}$ r.t..

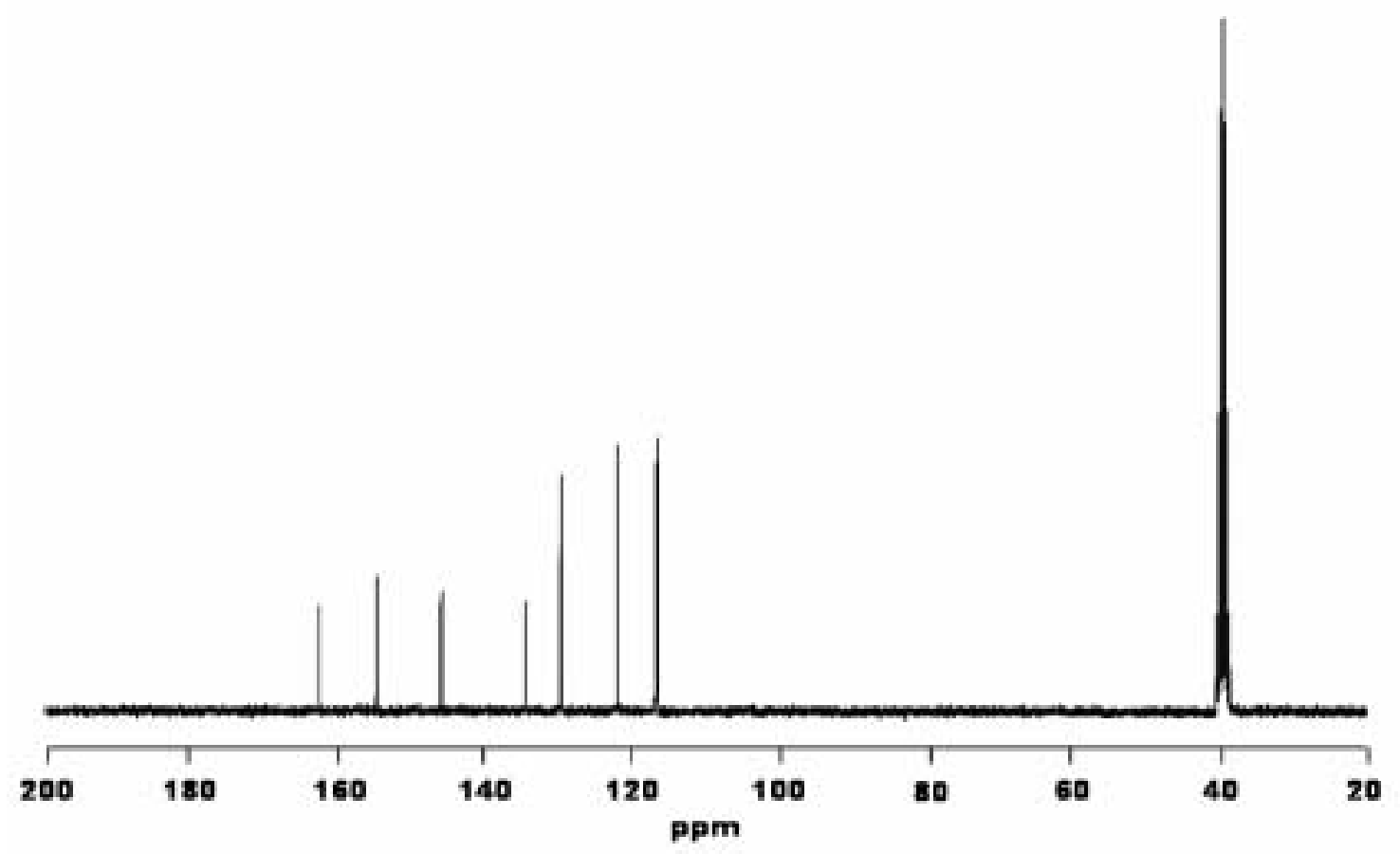

S-Figure 28. ${ }^{13} \mathrm{C}-\mathrm{NMR}$ spectrum of $\mathbf{1 3}$ in DMSO- $d_{6}$ r.t. 


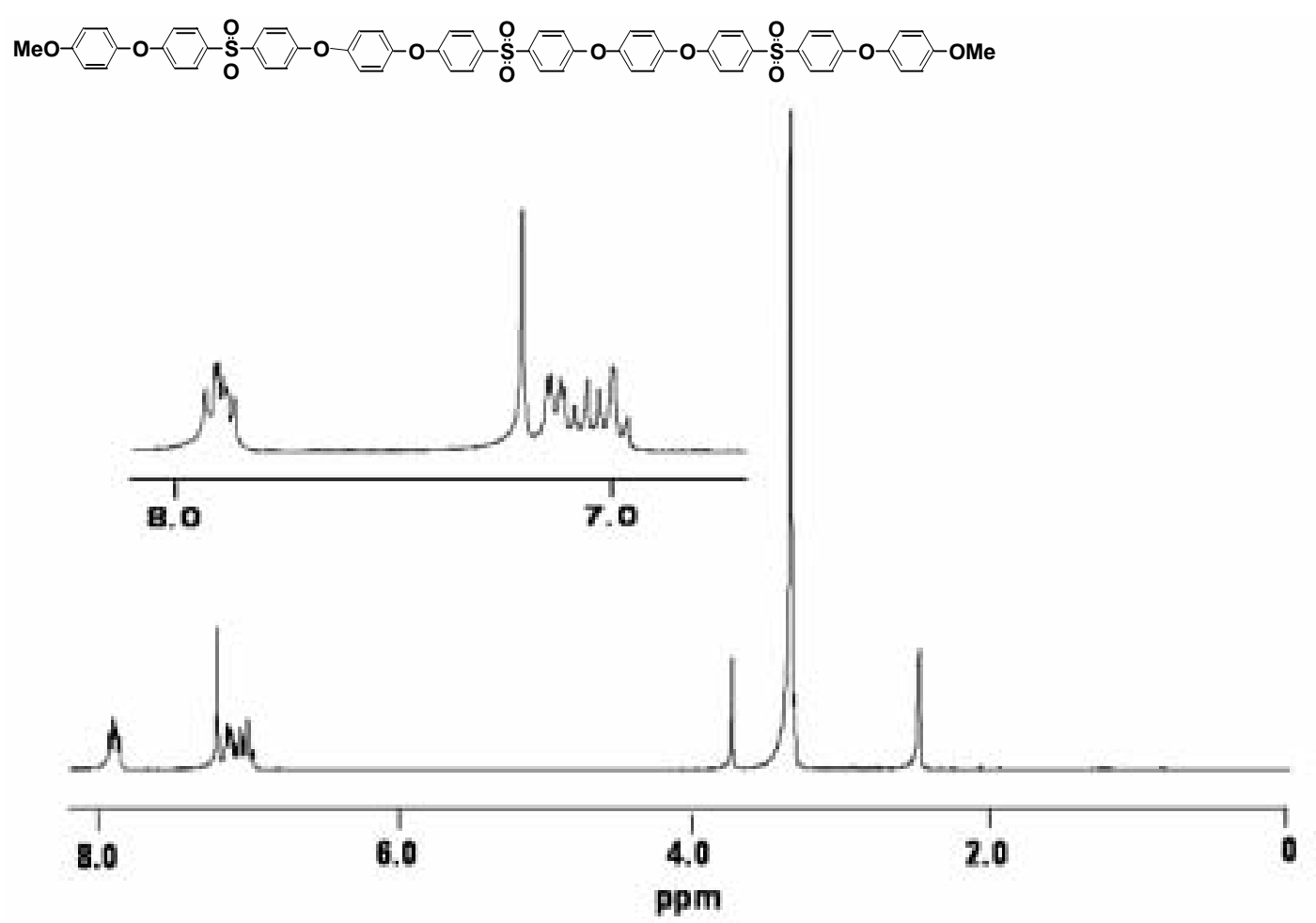

S-Figure 29. ${ }^{1} \mathrm{H}-\mathrm{NMR}$ spectrum of $\mathbf{1 4}$ in DMSO- $d_{6}$ r.t..

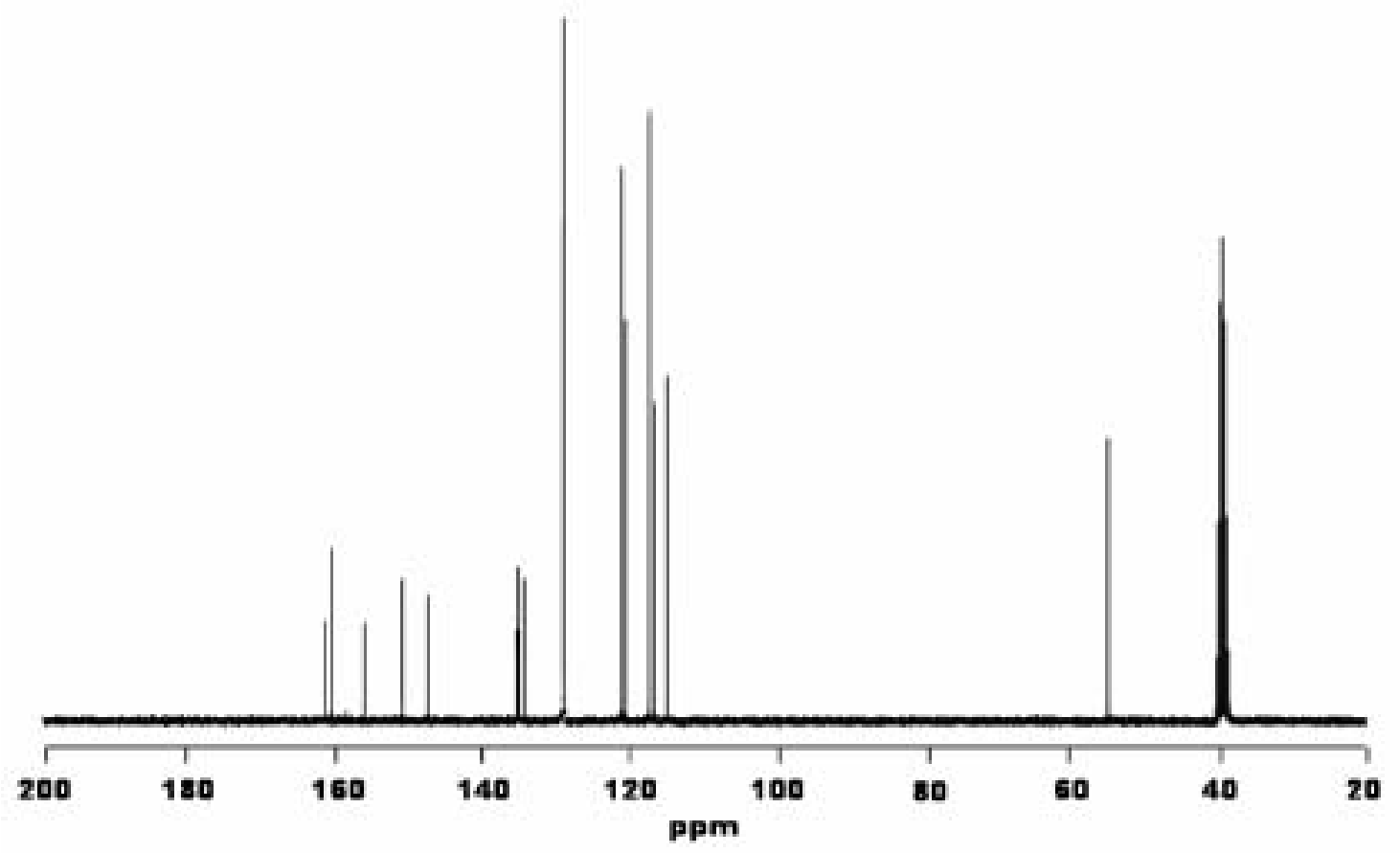

S-Figure 30. ${ }^{13} \mathrm{C}$-NMR spectrum of $\mathbf{1 4}$ in DMSO- $d_{6}$ at $120{ }^{\circ} \mathrm{C}$. 


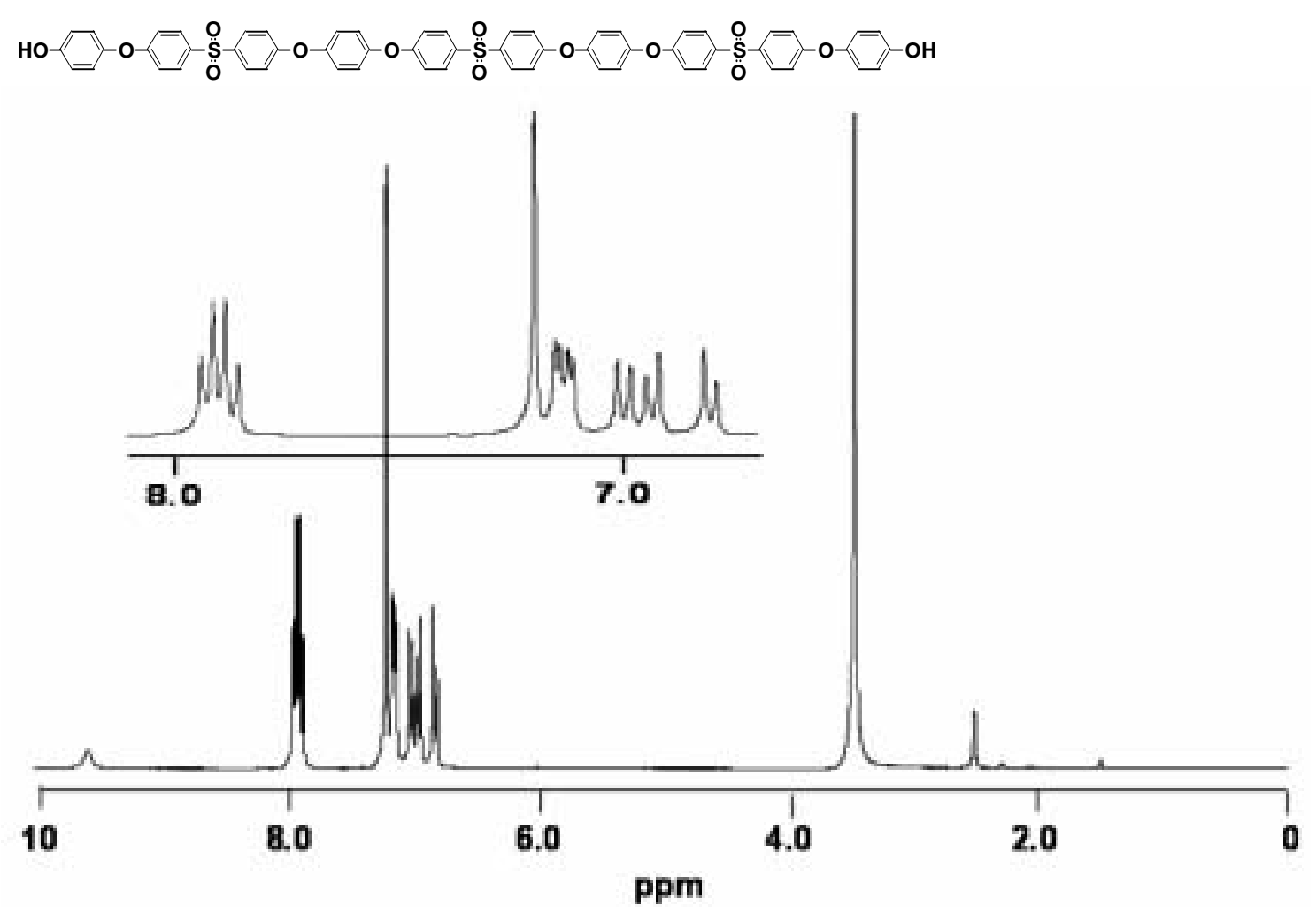

S-Figure 31. ${ }^{1} \mathrm{H}-\mathrm{NMR}$ spectrum of $\mathbf{1 5}$ in DMSO- $d_{6}$ r.t..

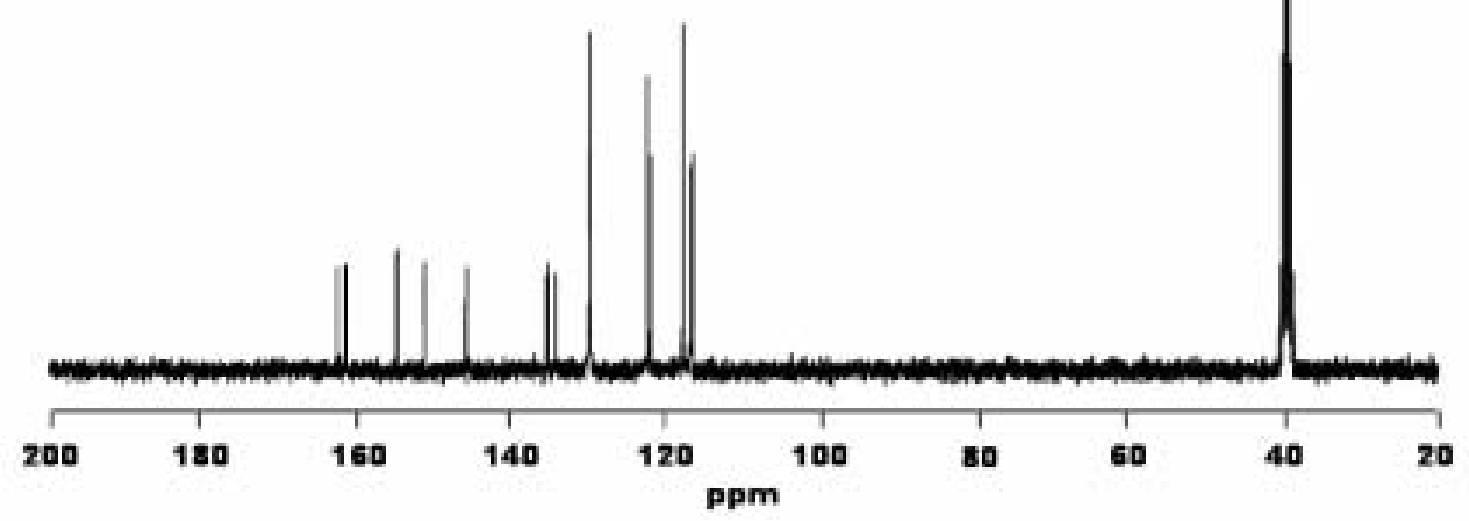

S-Figure 32. ${ }^{13} \mathrm{C}-\mathrm{NMR}$ spectrum of $\mathbf{1 5}$ in DMSO- $d_{6}$ r.t.. 


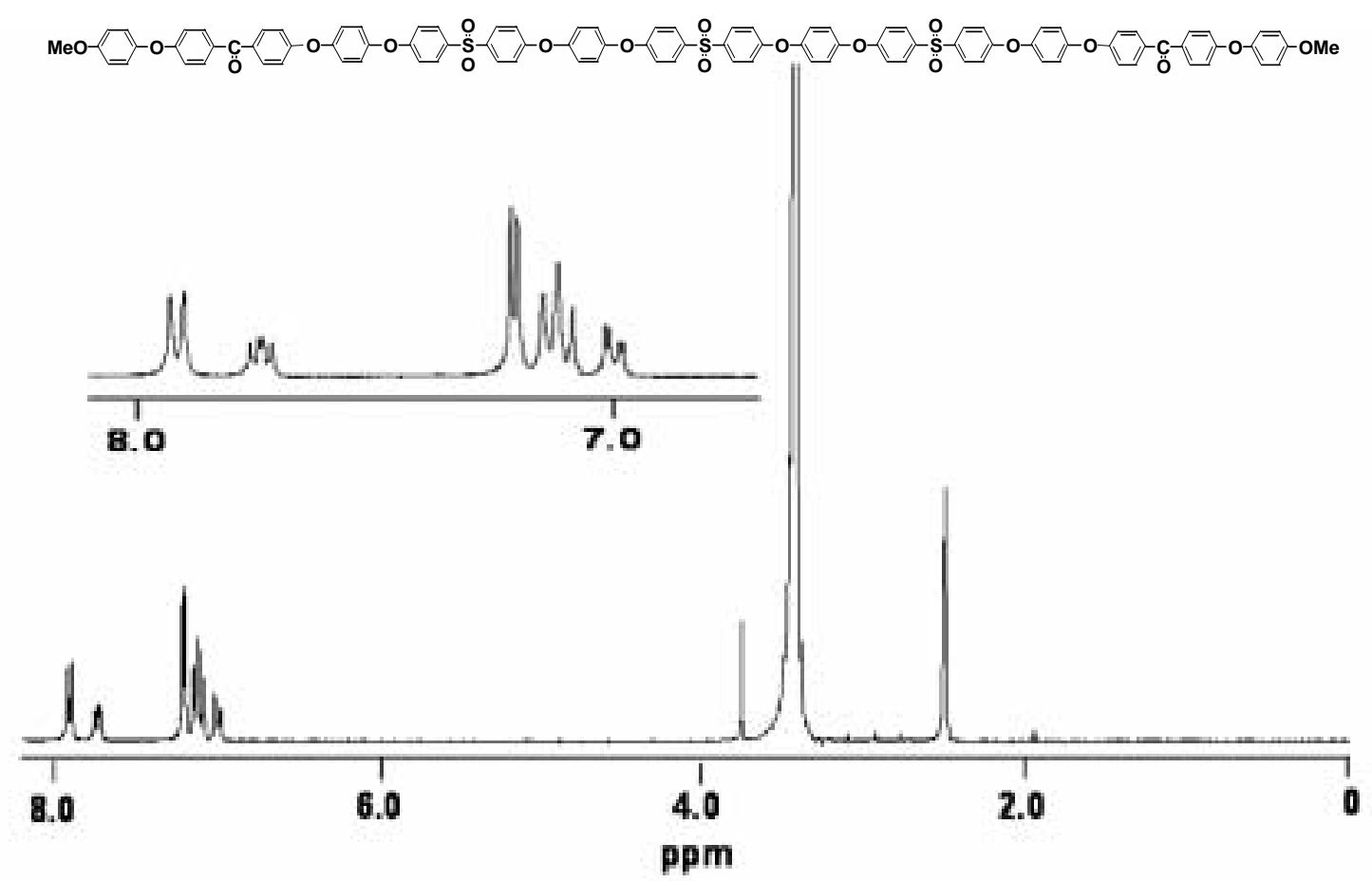

S-Figure 33. ${ }^{1} \mathrm{H}-\mathrm{NMR}$ spectrum of $\mathbf{1 6}$ in DMSO- $d_{6}$ r.t..

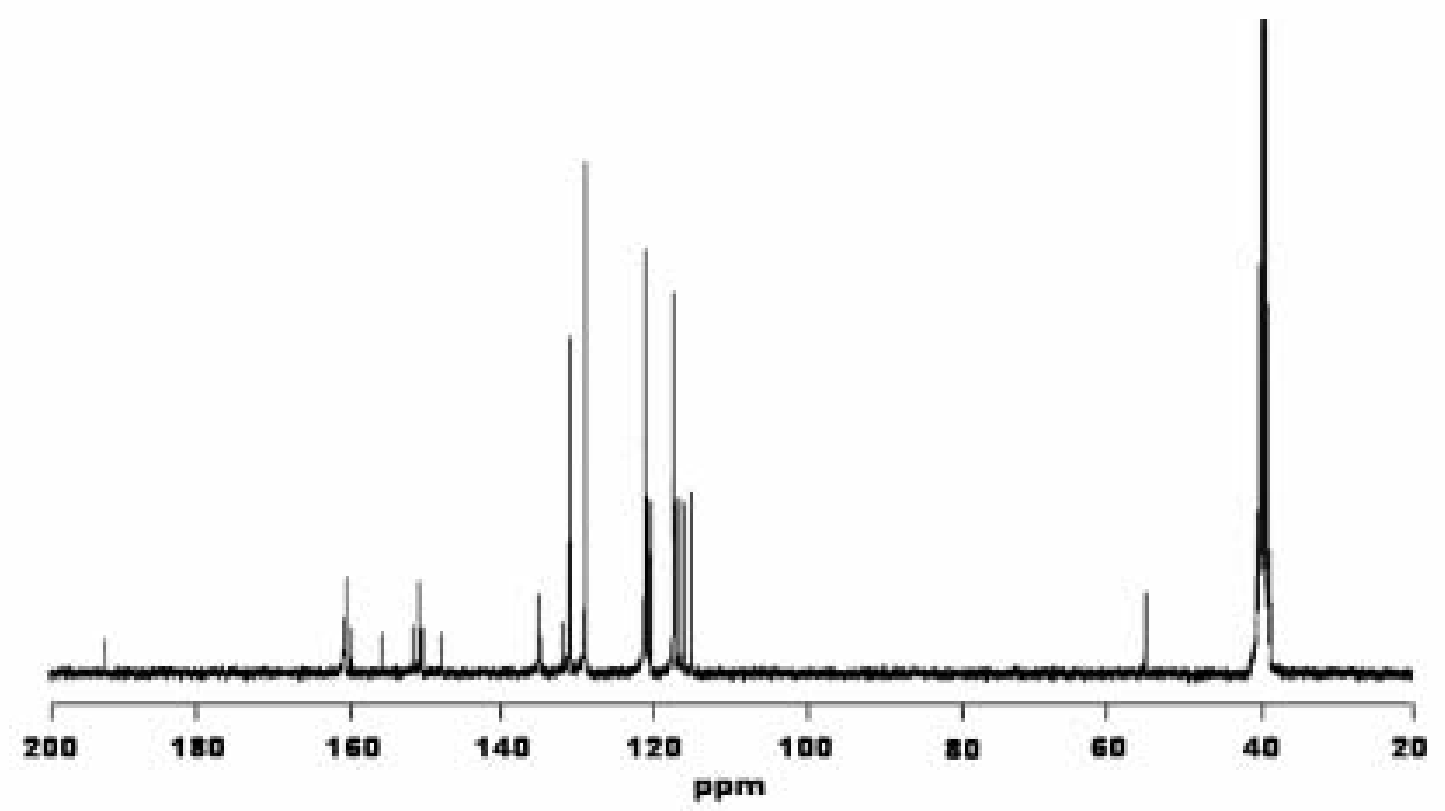

S-Figure 34. ${ }^{13} \mathrm{C}$-NMR spectrum of $\mathbf{1 6}$ in DMSO- $d_{6}$ at $120{ }^{\circ} \mathrm{C}$. 


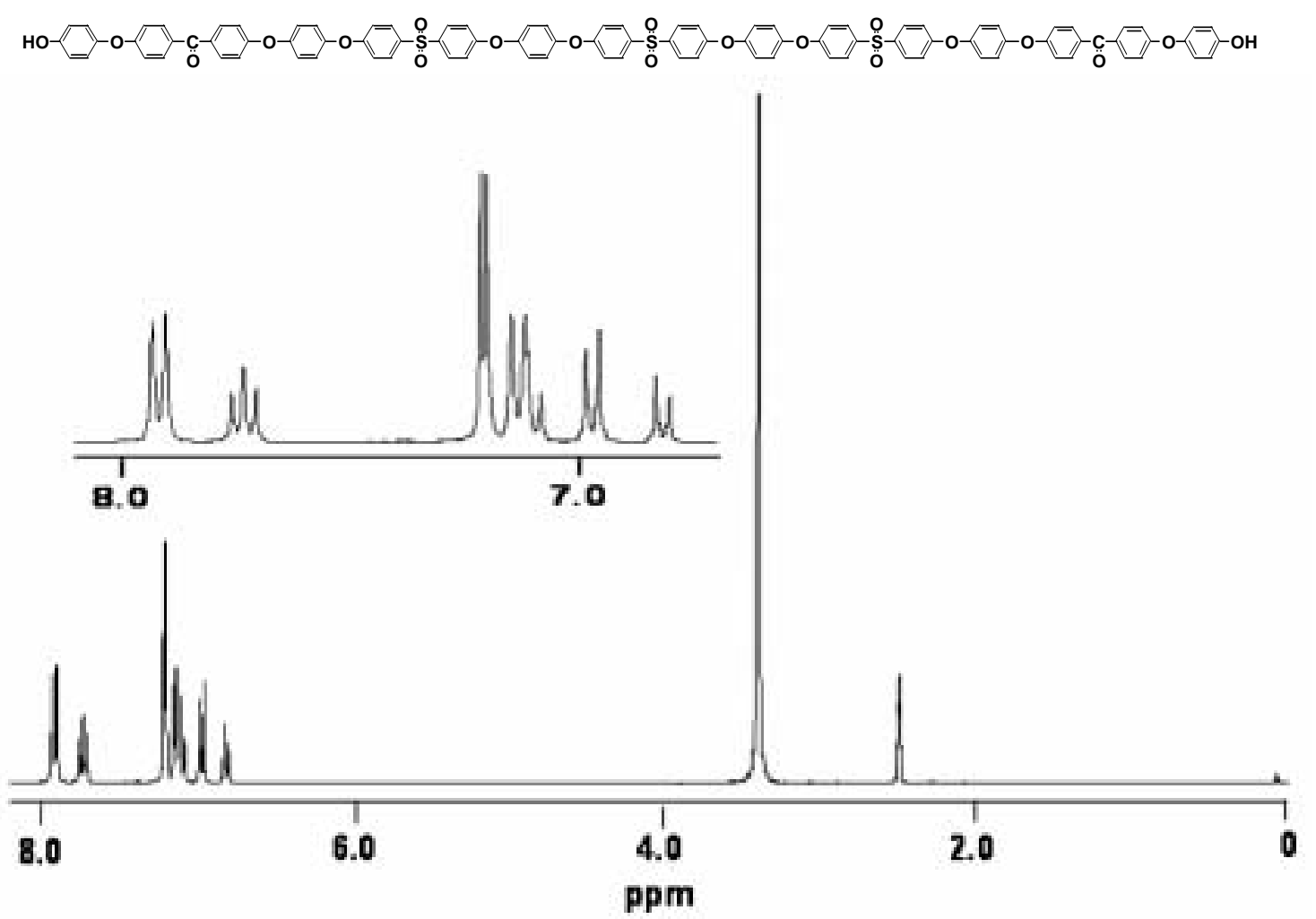

S-Figure 35. ${ }^{1} \mathrm{H}-\mathrm{NMR}$ spectrum of $\mathbf{1 7}$ in DMSO- $d_{6}$ r.t..

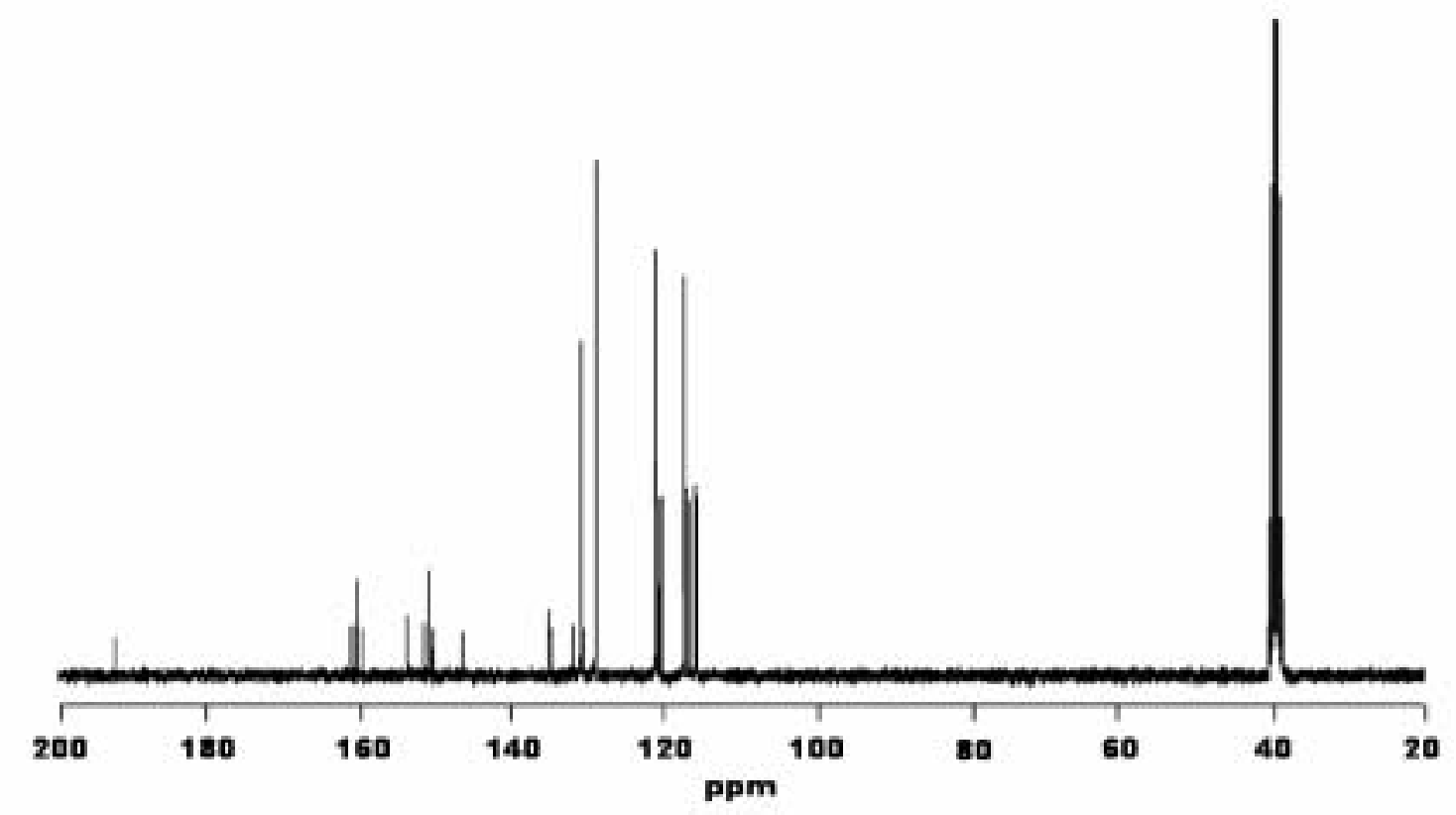

S-Figure 36. ${ }^{13} \mathrm{C}$-NMR spectrum of $\mathbf{1 7}$ in DMSO- $d_{6}$ at $120{ }^{\circ} \mathrm{C}$. 


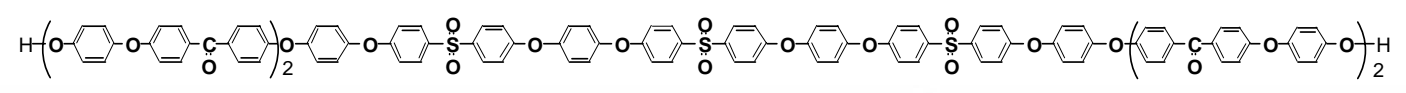
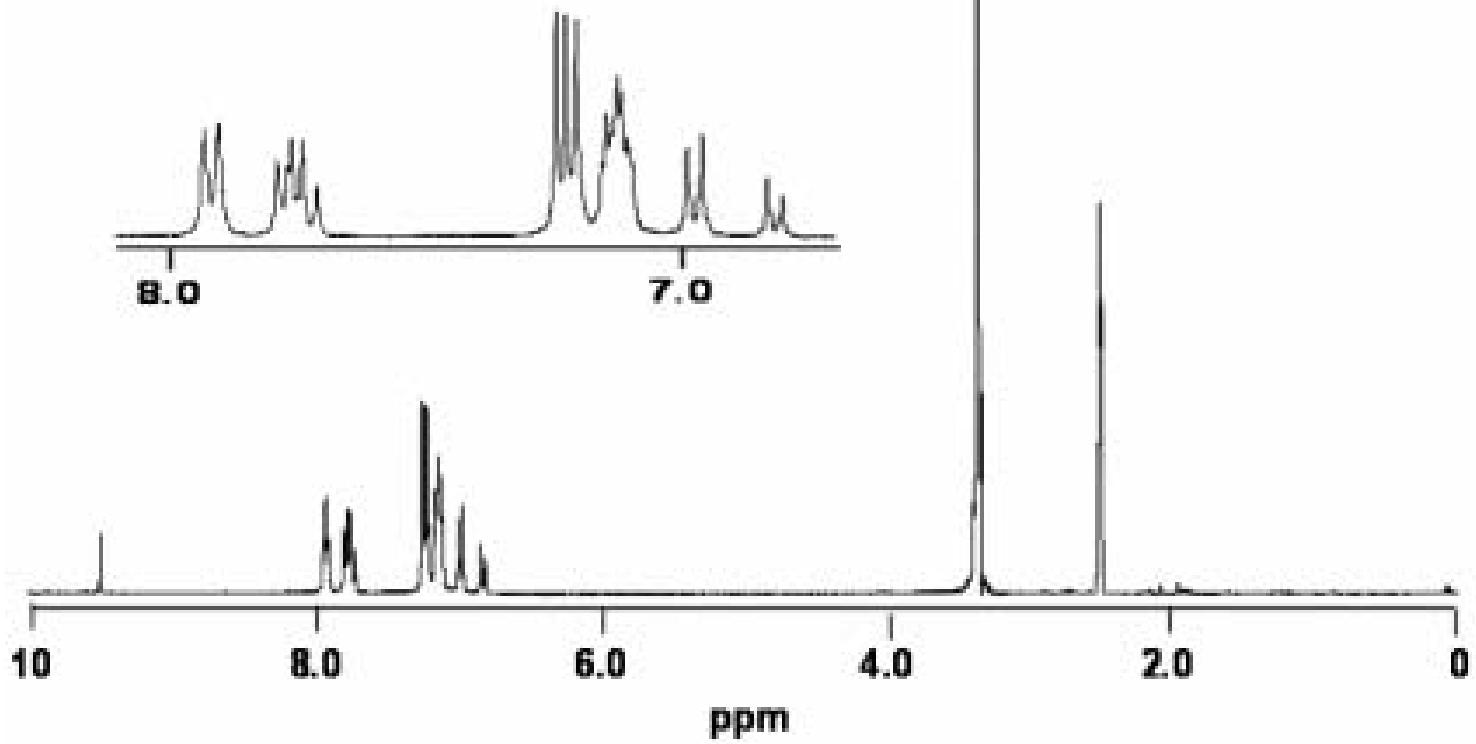

S-Figure 37. ${ }^{1} \mathrm{H}-\mathrm{NMR}$ spectrum of $\mathbf{1 9}$ in DMSO- $d_{6}$ r.t..

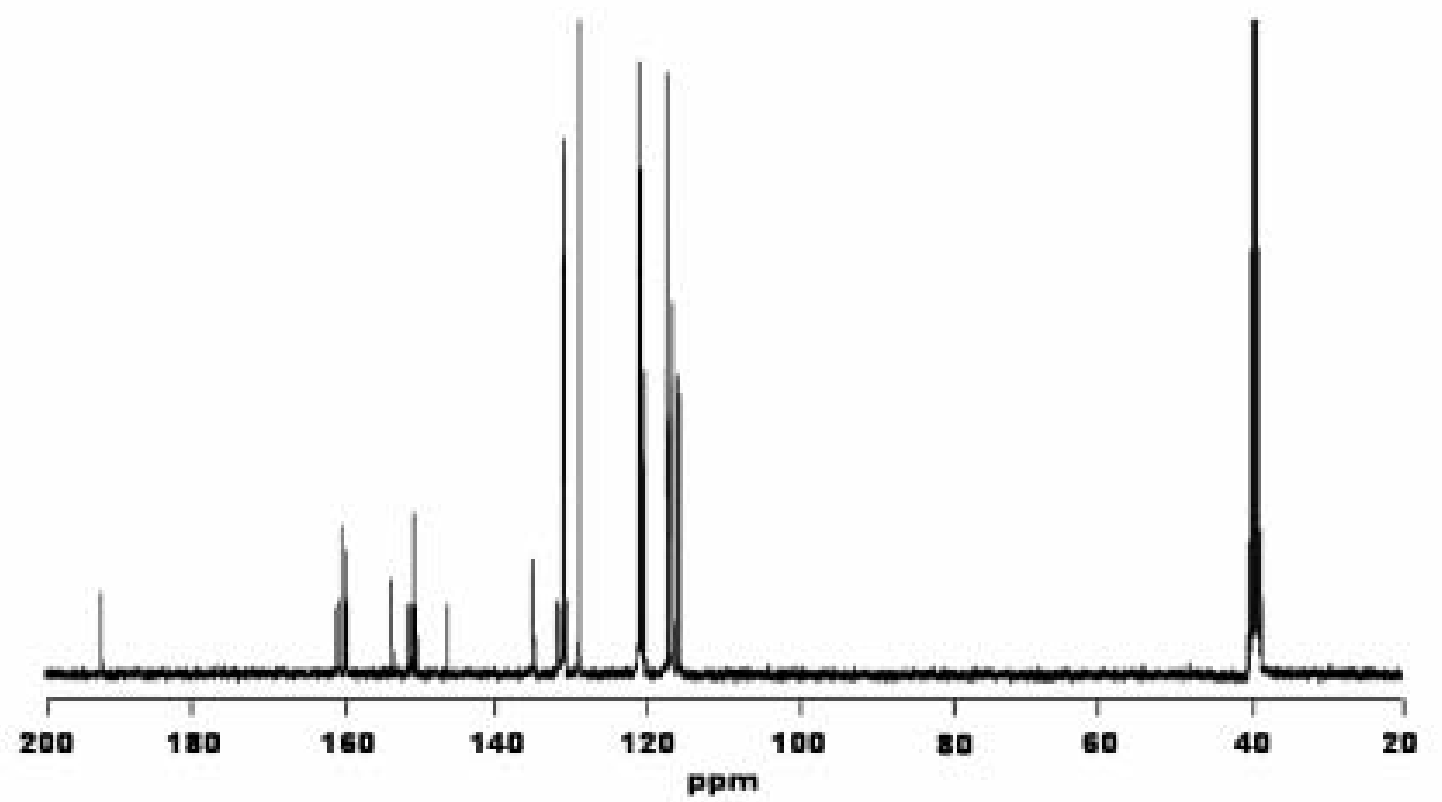

S-Figure 38. ${ }^{13} \mathrm{C}$-NMR spectrum of $\mathbf{1 9}$ in DMSO- $d_{6}$ at $120{ }^{\circ} \mathrm{C}$. 


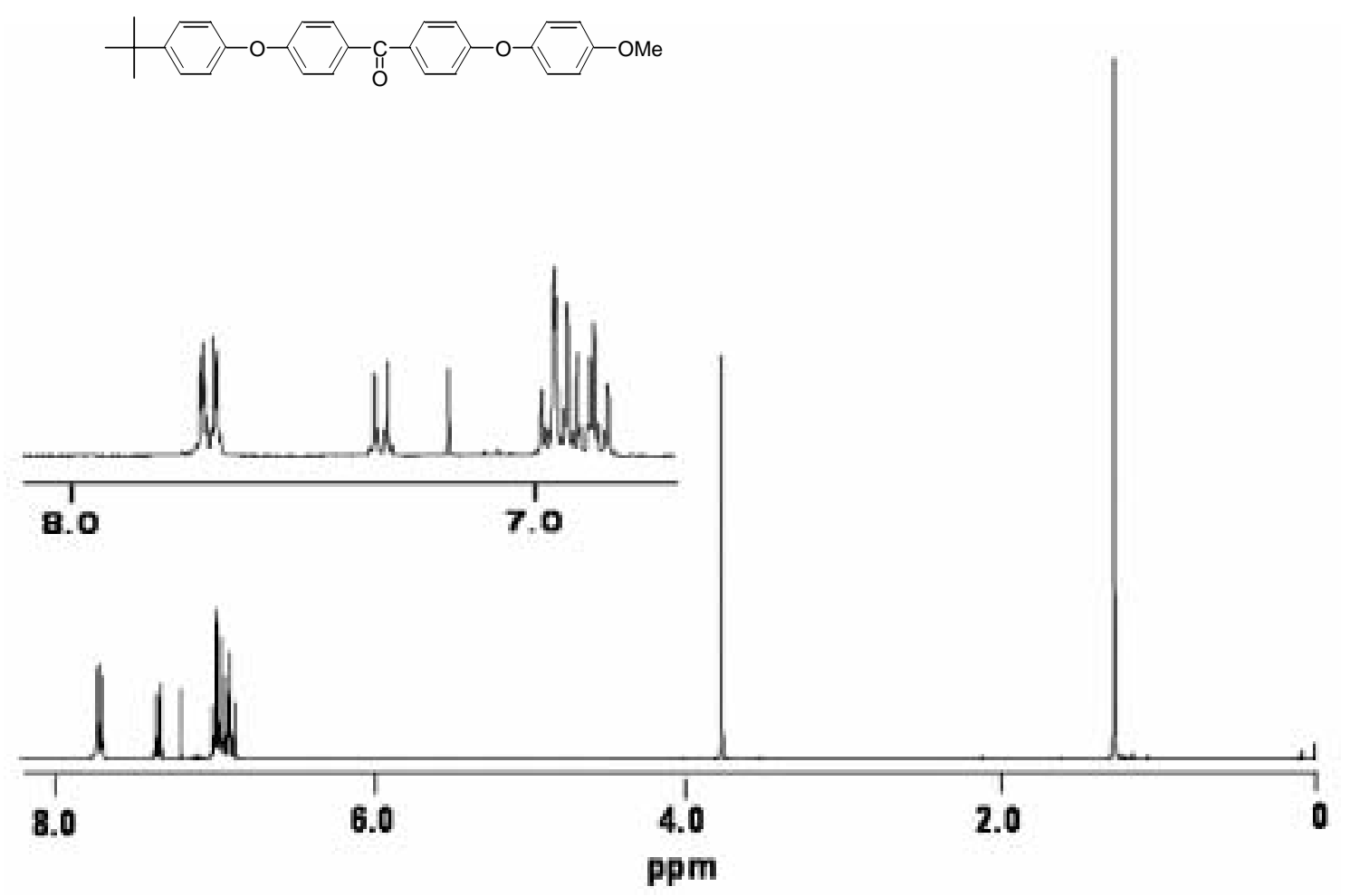

S-Figure 39. ${ }^{1} \mathrm{H}-\mathrm{NMR}$ spectrum of 20 in $\mathrm{CDCl}_{3}$ r.t..

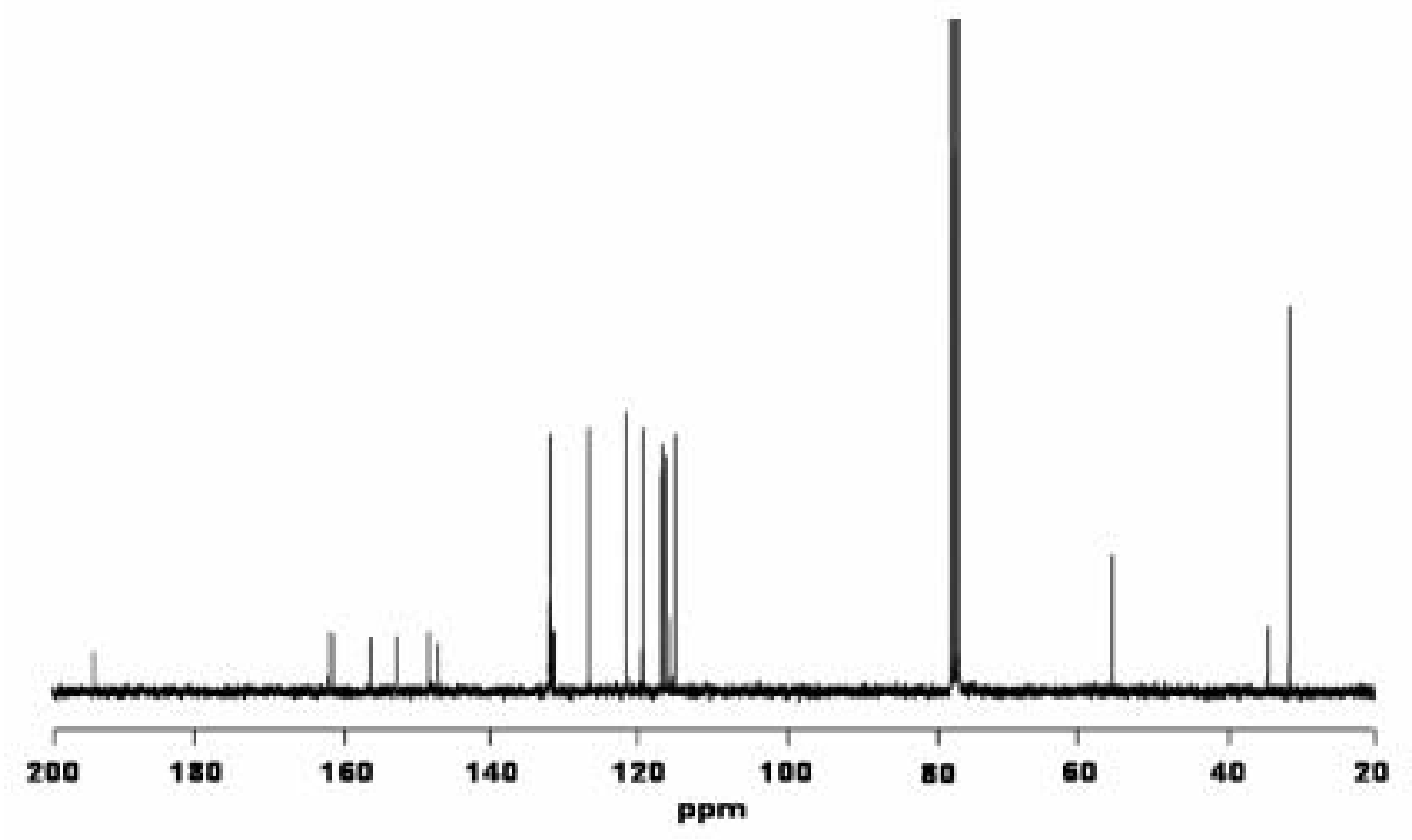

S-Figure 40. ${ }^{13} \mathrm{C}-\mathrm{NMR}$ spectrum of $\mathbf{2 0}$ in $\mathrm{CDCl}_{3}$ r.t.. 

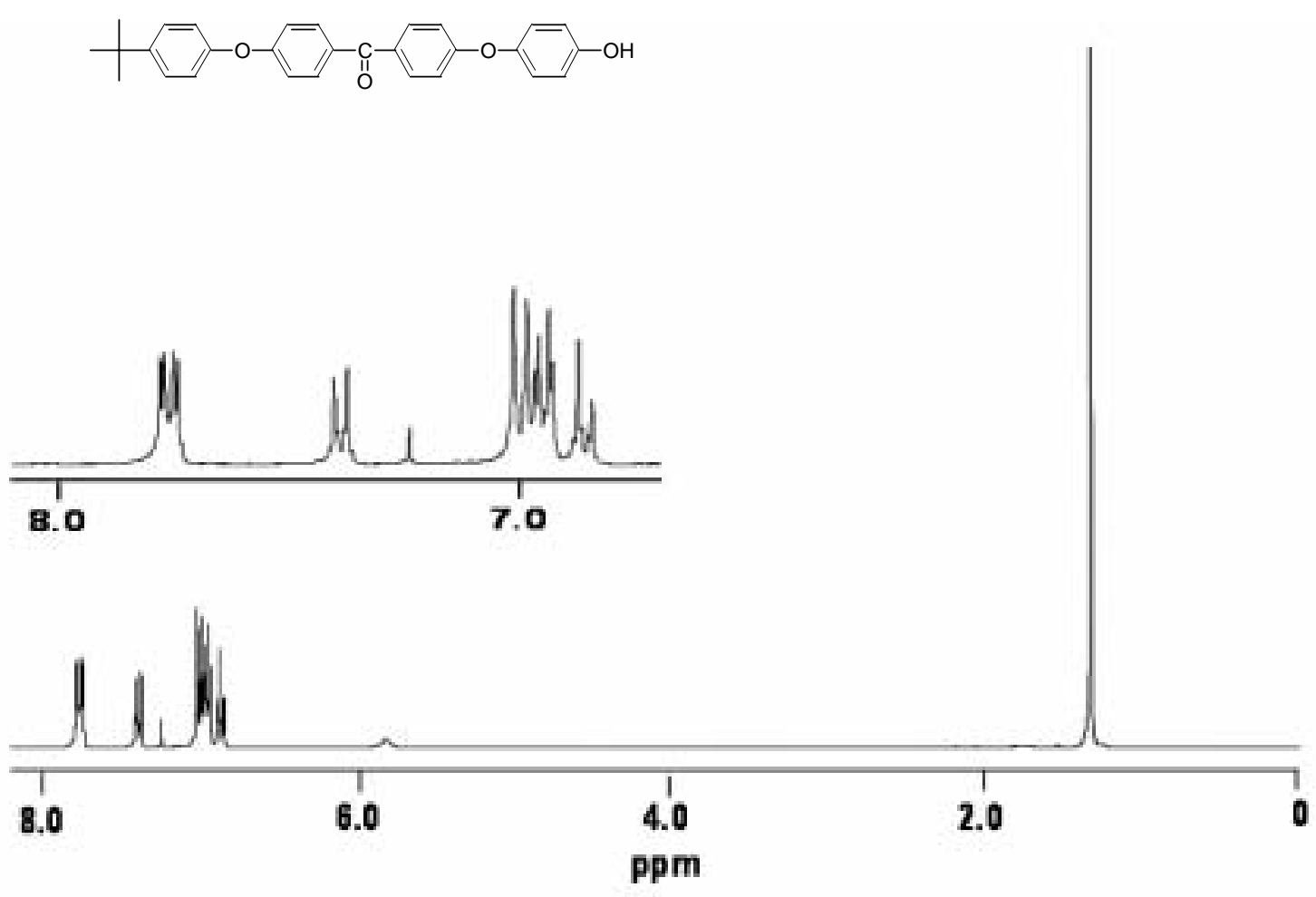

S-Figure 41. ${ }^{1} \mathrm{H}-\mathrm{NMR}$ spectrum of 21 in $\mathrm{CDCl}_{3}$ r.t..

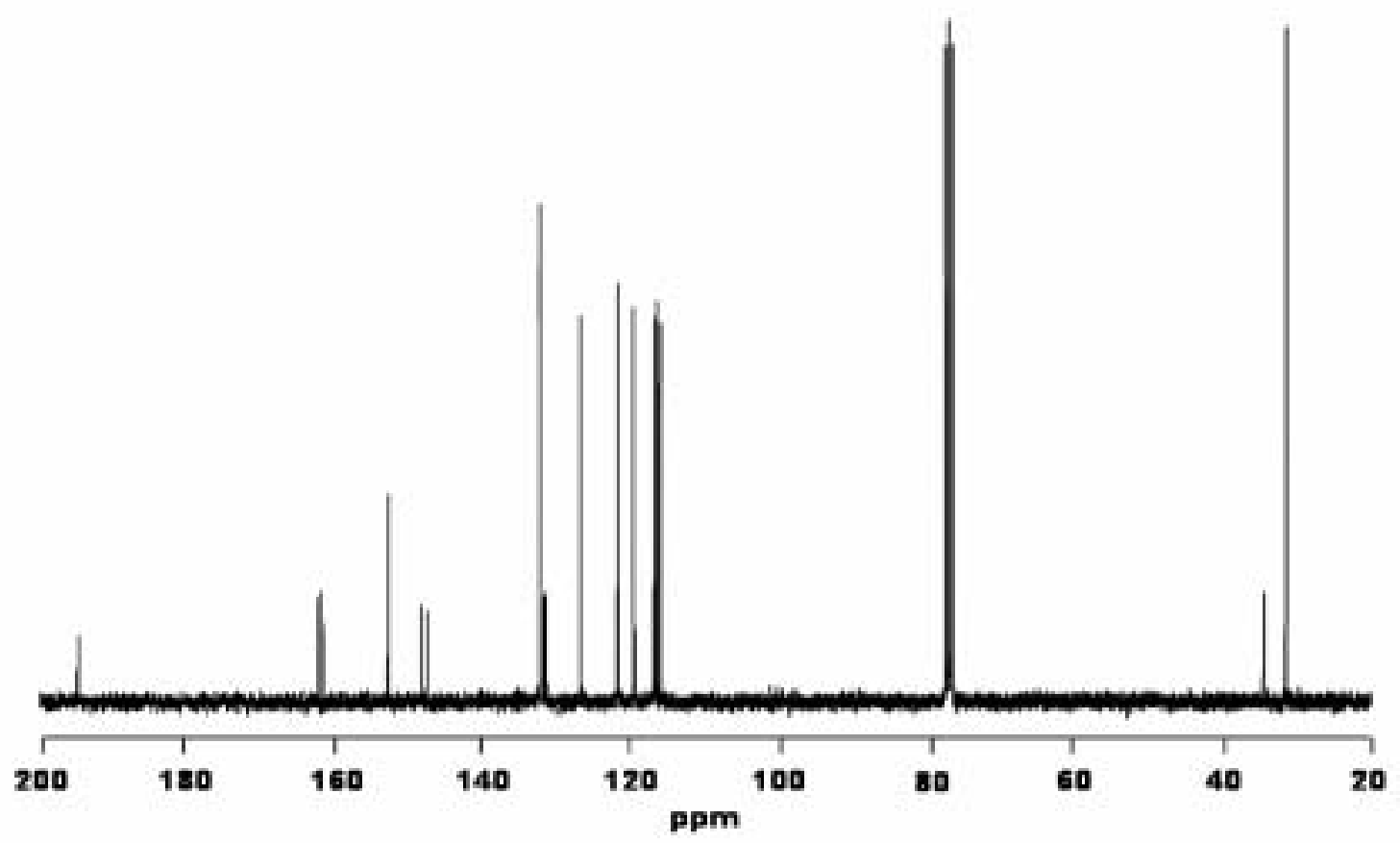

S-Figure 42. ${ }^{13} \mathrm{C}$-NMR spectrum of 21 in $\mathrm{CDCl}_{3}$ r.t.. 


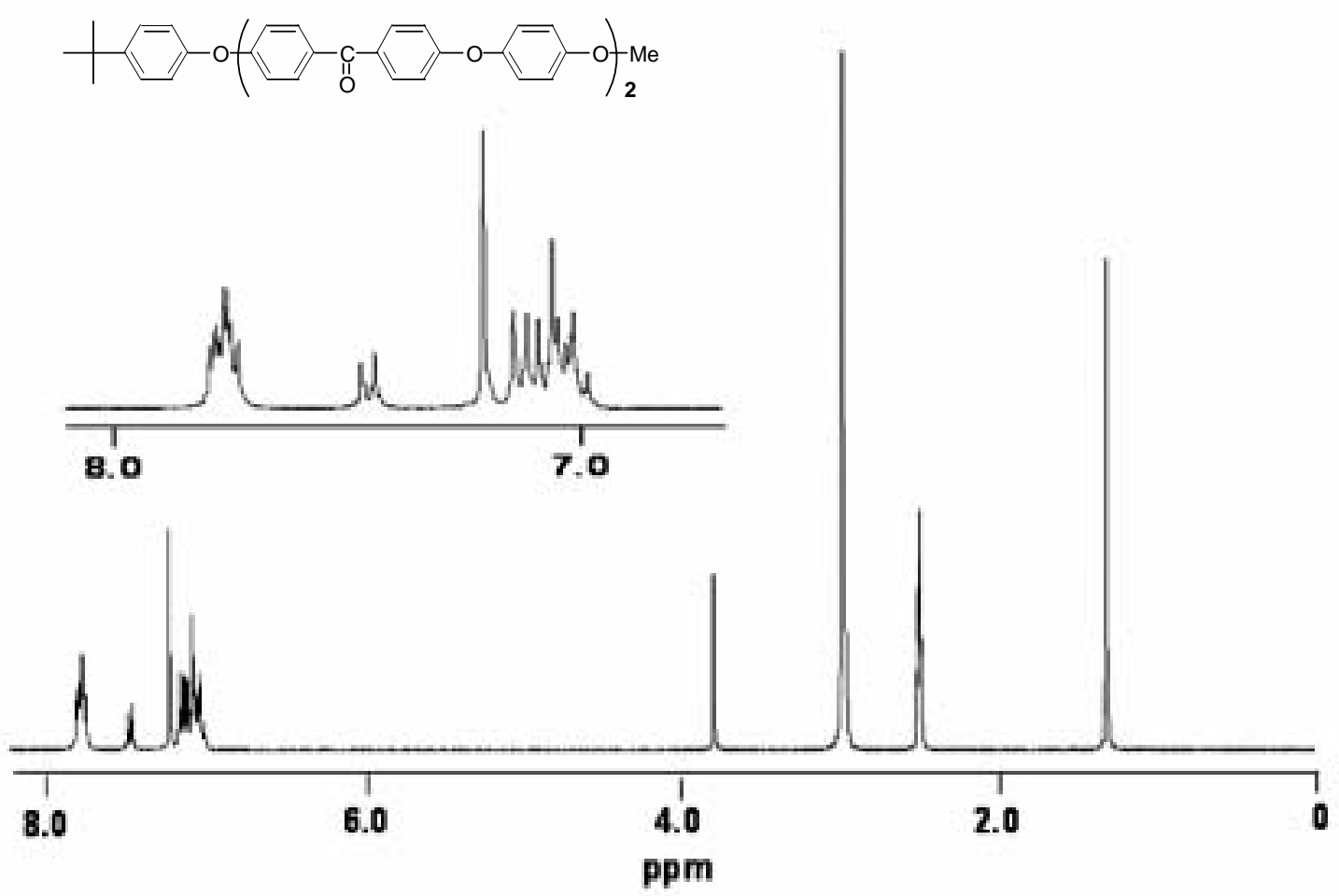

S-Figure 43. ${ }^{1} \mathrm{H}-\mathrm{NMR}$ spectrum of 22 in DMSO- $d_{6}$ r.t.

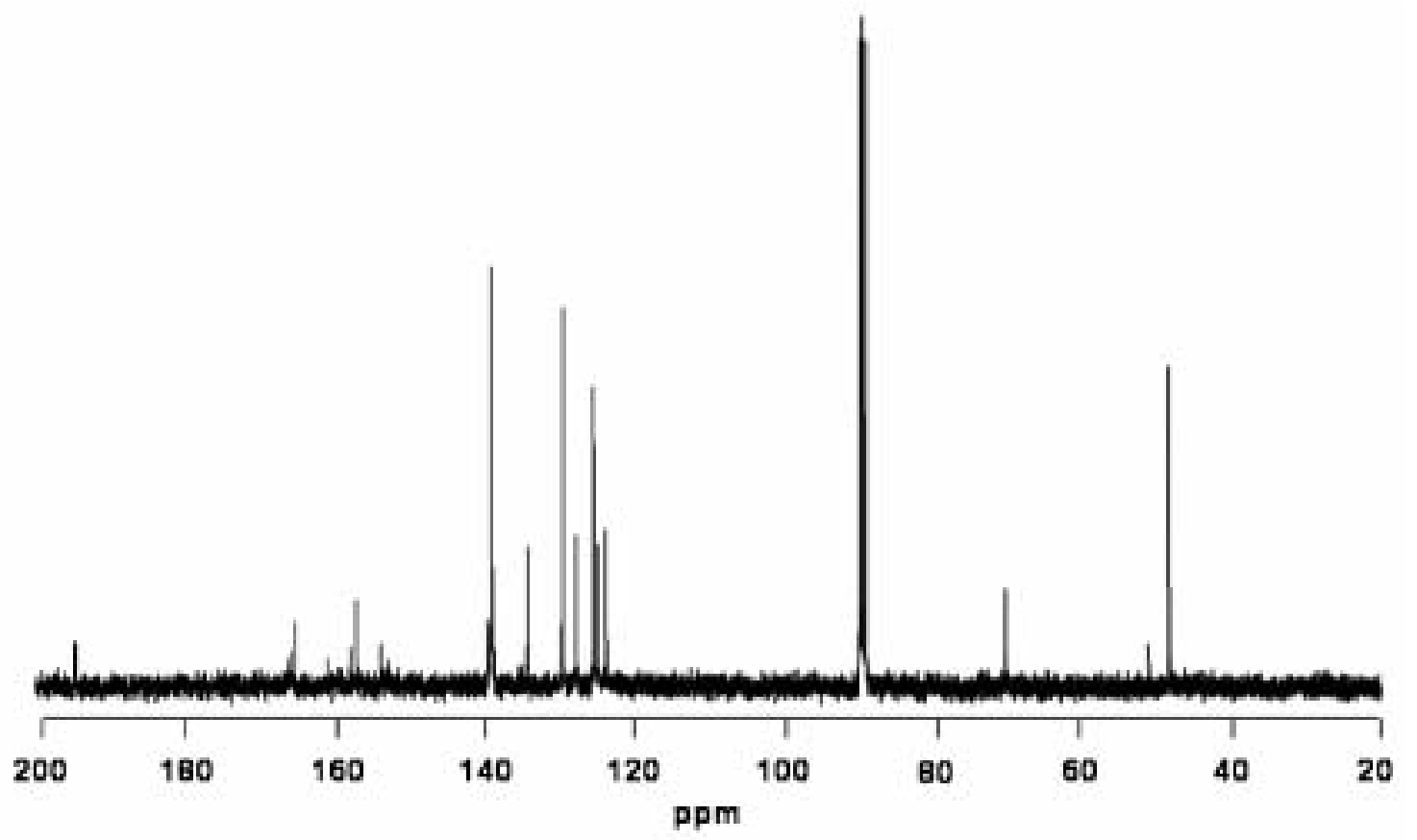

S-Figure 44. ${ }^{13} \mathrm{C}$-NMR spectrum of 22 in $\mathrm{CDCl}_{3}$ r.t.. 